Florida International University FIU Digital Commons

3-28-2013

\title{
Barcelona: Espacio Literario, Espacio Urbano en la Novela Catalana Femenina del Siglo XX
}

Elisabeth Llaveria-Powell

Florida International University, elisabethllaveria@gmail.com

DOI: $10.25148 /$ etd.FI13042309

Follow this and additional works at: https://digitalcommons.fiu.edu/etd

Part of the Spanish Literature Commons

\section{Recommended Citation}

Llaveria-Powell, Elisabeth, "Barcelona: Espacio Literario, Espacio Urbano en la Novela Catalana Femenina del Siglo XX" (2013). FIU Electronic Theses and Dissertations. 851.

https://digitalcommons.fiu.edu/etd/851 


\title{
FLORIDA INTERNATIONAL UNIVERSITY
}

Miami, Florida

\section{BARCELONA: ESPACIO LITERARIO, ESPACIO URBANO EN LA NOVELA CATALANA FEMENINA DEL SIGLO XX}

\author{
A dissertation submitted in partial fulfillment of \\ the requirements for the degree of \\ DOCTOR OF PHILOSOPHY \\ in \\ SPANISH \\ by
}

Elisabeth Llaveria-Powell 
To: Dean Kenneth G. Furton

College of Arts and Sciences

This thesis, written by Elisabeth Llaveria-Powell, and entitled Barcelona:Espacio Literario, Espacio Urbano en la Novela Catalana Femenina del Siglo XX, having been approved in respect to style and intellectual content, is referred to you for judgment.

We have read this thesis and recommend that it be approved.

$\begin{array}{r}\text { Sherry Johnson } \\ \hline \text { Santiago Juan-Navarro } \\ \hline \text { Ricardo Castells } \\ \hline \text { Joan Torres-Pou, Major Professor }\end{array}$

Date of Defense: March 28, 2013

The thesis of Elisabeth Llaveria-Powell is approved.

Dean Kenneth G. Furton

College of Arts and Sciences

Dean Lakshmi N. Reddi

University Graduate School

Florida International University, 2013 


\section{ABSTRACT OF THE DISSERTATION \\ BARCELONA: ESPACIO LITERARIO, ESPACIO URBANO EN LA NOVELA CATALANA FEMENINA DEL SIGLO XX \\ by}

Elisabeth Llaveria-Powell

Florida International University, 2013

Miami, Florida

Professor Joan Torres-Pou, Major Professor

This dissertation analyses, through a rhetorical framework and a literary approach, texts written in Catalan and Castilian by four Catalan female writers (Dolors Monserdà, Maria Aurèlia Capmany, Esther Tusquets, Monserrat Roig ), whose works cover from 1900 to the 1980. Utilizing this urban feminine literature, it discusses the historicalgeographical vision about the changes in Catalan society during the twentieth century with its consequences for the urban space, especially the space occupied by women. It is also established that Barcelona's recovery and literary vindication by women has been done through the written text, as literary affirmation and as a matter of conscience in which the city could not be summed up as a backdrop, but rather as an active part of a literary creation, active in the double sense, as a socio-historical space in the novel and as characteristic of their works.

The primary purpose of this dissertation is to demonstrate that the use of the city as a setting for the novels determines and characterizes those female writers' texts. Consequently, these writings are literary material relevant and essential to the understanding of the Barcelonian women's space. However their use of space is not arbitrary, on the contrary it corresponds to a social order established by the patriarchy 
where the relation of women to the world is embodied in the intentional and socially restricted space and movements of their bodies.

The theoretical perspectives of this study are based on Montserrat Roig's feminist urban space theories. Her theory advocates the right to individuality, denouncing the patriarchal and hierarchical social system present in gendered space from the outside male world to the domestic feminized space. I also turn to the writings of Maria Aurèlia Capmany, who addresses cultural aspects of women's roles revealing a purposive controlled patriarchal society according to a historical-geographical analysis. This study of texts permits a new reading of the Catalan capital and demonstrates that Catalan women writers have consciously willed to give birth to a new history of the city: the history of women as protagonist citizens, producers, reproducers, and consumers of the space represented by the Catalan capital 


\section{ÍNDICE}

CAPÍTULO PAGE

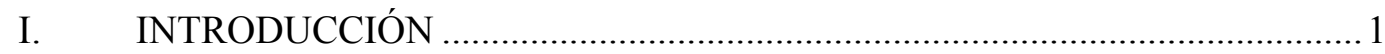

II. LA FABRICANTA. NOVEL.LA DE COSTUMS BARCELONINES (1860-

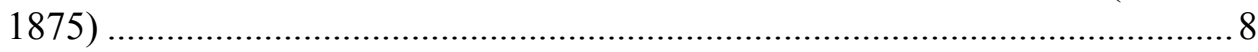

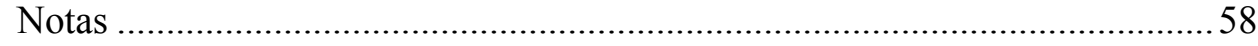

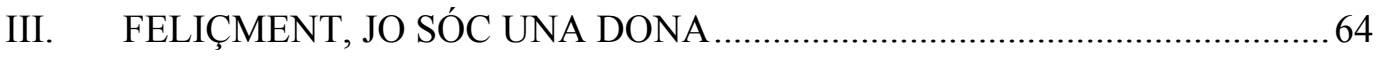

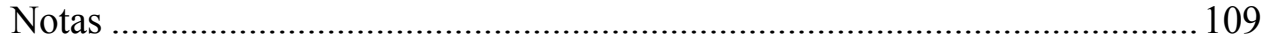

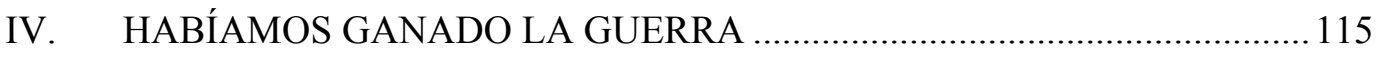

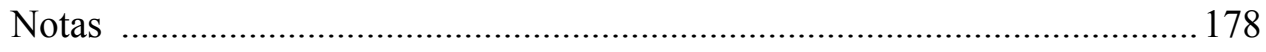

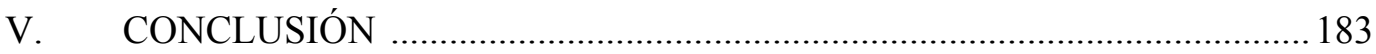

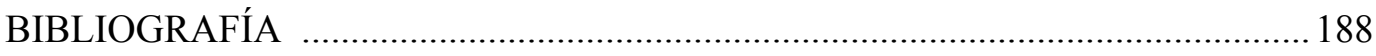

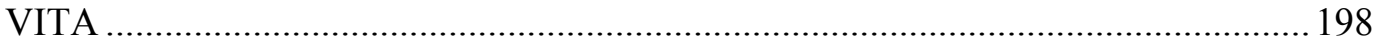




\section{Introducción}

La ciutat (...) ha anat oferint a les dones durant segles diversos radis de visió construïts amb figures geomètriques. Les dones han vist el món rodó, rectangular o quadrat. De vegades eren unes línes paral.leles, estretes, que acabaven a la fàbrica. (...) I els arquitectes anaven obrint, segons el temps i segons les clases, les obertures de les cases, les finestres, balcons o galeries, tot ignorant, potser, que a través d'elles hi havia una mirada que volia volar. Dama, senorya, menestrala o xinxa: el camp de visió variava una mica però, sense elles saber-ho, l'actitud de mirar les unia. Era una mirada que encara no havia trobat les paraules, les seves, per expresar allò que veia. I ès això el que li feia falta a a la historia de Barcelona. I a la seva literatura.. (Digues que m'estimes encara que sigui mentida, Roig 165)

Con el siglo XX, Barcelona, no solo se ha convertido en la ciudad del Estado español donde se conceden los premios literarios más prestigiosos, sino que ella misma ha pasado a ser un preciado tema literario, de tal manera que las novelas sobre la ciudad condal han recibido una excelente acogida en el mundo de la publicación. Sin embargo, a pesar de ese éxito, la gran mayoría de los estudios sobre la literatura urbana barcelonesa se ha limitado a estudiar la narrativa masculina. Así es posible encontrar abundante bibliografía sobre la relación con Barcelona de autores como Manuel Vázquez Montalbán, Juan Marsé, Luis Goytisolo o Eduardo Mendoza, pero bien poco tenemos por lo que se 
refiere a las escritoras. Un aspecto que es aún más evidente cuando se trata de autoras que escriben en catalán y que indica de manera incuestionable el poco interés que la narrativa urbana femenina y catalana tiene para el mundo académico. En este estudio, he intentado apuntar la importancia de este aspecto de la producción literaria y esbozar, mediante el análisis de tres textos catalanes y uno castellano que abarcan de mediados del siglo XIX a finales del XX, los aspectos más importantes y característicos de la misma.

Asimismo, a partir de esta literatura urbana femenina, este trabajo analiza la visión histórico-geográfica de las transformaciones de la sociedad catalana a lo largo del siglo $\mathrm{XX}$ con sus consecuencias en el espacio urbano, sobre todo en el espacio vivido por las mujeres. En las obras de Dolors Monserdà, Maria Aurèlia Capmany, Esther Tusquets y Montserrat Roig, Barcelona se define por las relaciones que las autoras tienen con la ciudad. Al mismo tiempo esta dependencia constituye el centro de todas las novelas estudiadas y establece una doble identidad tanto al nivel humano como urbano.

En el estudio del papel que juega Barcelona en la obra de estas autoras, destacó que el uso de la ciudad en las novelas y en los libros de memorias determina y caracteriza los textos de estas escritoras, las cuales denuncian que la utilización del espacio no es arbitraria, sino que corresponde a una ideología, a un orden social y funcional establecido por el patriarcado. Al mismo tiempo, es mi propósito analizar a la palabra literaria femenina y revelar la visión de la ciudad formulada por las mujeres como un acto para todas consciente y político, sobre todo en el caso de las autoras que escriben en catalán, puesto que para ellas la única herramienta disponible de denuncia social o política se situaba al nivel de la escritura.

A la luz de diversas teorías sobre la ciudad y el espacio en la literatura he intentado demostrar que el uso de la ciudad de Barcelona, como espacio literario, 
caracteriza y determina la escritura de estas autoras y que ese "escribir" Barcelona debe verse como una recuperación de la ciudad y de la identidad catalana. A tal fin, acudo a los textos de algunos teóricos que han reflexionado sobre el papel que juega el espacio en la narrativa, como Gaston Bachelard, Mijaíl Bajtin, Burton Pike, Gérard Genette, sin olvidar la geografía del género deLinda McDowell, quien establece que los procesos y las condiciones sociales transforman las características biológicas en categorías sociales. Estas diferentes escuelas críticas ofrecen diversidad al análisis y permiten un estudio más profundo de los textos. Por ejemplo, aplicando la teoría de Bachelard demuestro que el universo de la mujer se resume muchas veces al de la casa o del barrio en el sentido acogedor y procreador de espacio uterino, por lo que Barcelona se percibe como madre, estableciéndose entre mujer y ciudad una relación filial que funda y sella una pertenencia mutua y casi genética.

Con todo, es la crítica literaria del espacio urbano realizada por Montserrat Roig la que me ha permitido plantear la percepción y la visión del espacio urbano a partir de la mirada de la mujer. Su teoría preconiza el derecho a la diferencia, la importancia de la cultura e identidad catalana, alejándose del feminismo francés, e inclinándose más hacia el lado combatiente del feminismo anglosajón. Es de precisar, que para Roig, la reconstrucción y la recuperación de Barcelona no puede hacerse sin primero establecer una historia de la mujer barcelonesa. Esta búsqueda a través del tiempo nos proyecta hacia unos espacios imaginarios de la ciudad. Según Roig, necesitamos acudir a la imaginación para poder llenar todos los espacios blancos que siglos de opresión y represión han silenciado. Su escritura es, principalmente, una narrativa de denuncia y, en su libro Dime que me quieres aunque sea mentira, acusa claramente al sistema patriarcal de haber encerrado y privado a la mujer del espacio urbano, forzándola a recurrir a su 
imaginario. También recurro a los textos de Maria Aurèlia Capmany, quien con una consciencia política aguda, nunca separó su escritura de sus reivindicaciones izquierdistas y catalanistas. Es de notar que Capmany siempre escribió en catalán y que su lucha para el reconocimiento oficial de la identidad y lengua catalana no puede nunca separarse de su lucha por la condición femenina. De hecho, es autora de la primera historia moderna del feminismo y de la situación de la mujer catalana (del siglo XIX hasta finales del siglo $\mathrm{XX}$ ). Su feminismo se construye sobre argumentos biológicos, sicológicos, históricos y sobre la crítica literaria feminista europea (francesa y anglosajona). Por último, utilizo la teoría feminista de Hélène Cixous, la cual se basa sobre la lengua como terreno esencial en el pensamiento, para reflejar sobre el hecho que la mujer nunca ha tenido su lengua propia, por lo que, a través de la literatura, va a usar el lenguaje para abrir otros espacios.

Este trabajo está dividido en tres capítulos que siguen la siguiente estructura: el primero estudia la novela La fabricanta (1904) de Dolors Monserdà, como la primera novela feminista y urbana en Catalunya. Tras una breve introducción a las condiciones socioeconómicas de la época se explica la importancia y las consecuencias de la Revolución Industrial del siglo XIX en la sociedad barcelonesa. A continuación, a través del estudio de la protagonista, Antonieta, una burguesa de la clase media, analizo la visión femenina de sus experiencias personales, y el papel de los espacios urbanos interiores y exteriores en la obra, así como de la vida social y privada de algunos barrios barceloneses de la época. Es el testimonio que encontramos en la novela de la vida barcelonesa lo que comento con mayor detalle, pues la autora nos procura en esta obra datos valiosísimos para conocer, entender, establecer y recuperar la vida de las mujeres desde la perspectiva de una de ellas. Este aspecto nos permite también demostrar que Barcelona es mucho más que un telón de fondo, y que es un elemento esencial al texto convirtiéndose en la imagen 
simbólica de la nueva literatura urbana femenina. Barcelona nace de la mirada de Antonieta y en su personje, Monserdà nos presenta la nueva mujer catalana y la nueva Barcelona para quien la lengua y la tierra catalana son partes incondicionales de su escritura e identidad. Asimismo, establezco una estrecha analogía entre Antonieta y Barcelona, puesto que las cualidades con las que se describe a la protagonista son un claro reflejo de las características atribuibles a la Barcelona de fin de siglo. Es un juego de espejos en el que la modernidad de Barcelona se confunde con la modernidad de un nuevo tipo de mujer.

En el segundo capítulo, la novela estudiada es Feliçment, sóc una dona (1969) de Maria Aurèlia Capmany, una novela que también tiene como protagonista principal una mujer inteligente, pero en este caso pobre, y sometida a una sociedad patriarcal. Empiezo con un breve repaso del contexto socio cultural en el cual escribe la autora, quien pertenecía a la generación de las escritoras de la posguerra, y muestro como la novela se presenta como un Bildungsroman, que narra el proceso de ascendencia social y personal de la protagonista (Carola), en un espacio barcelonés lleno de implicaciones históricas. Establezco un paralelismo entre la formación de Carola y la de Barcelona a partir de lo cual se puede afirmar que Feliçment, jo soc una dona constituye también el Bildungsroman de la "formación" de Barcelona. Esta analogía a su vez conduce a demostrar que Barcelona es el personaje principal del libro, pero que se presenta a modo de palimpsesto ocultándose tras la imagen más evidente de Carola. Percepción que solamente será posible para aquellos que estén familiarizados con la historia reciente de la ciudad. Por lo tanto, Barcelona como elemento literario indispensable, define las acciones, los entornos político-sociales, los acontecimientos, los espacios y hasta la sexualidad. A través de la ciudad condal, Capmany da a la protagonista el espacio necesario para su 
crecimiento como mujer y como ciudadana estableciendo que determinados ambientes sociales confieren formas distintas a la mujer que se adapta a ellos.

En el tercer capítulo me centro principalmente en la autobiografía de Esther Tusquets Habíamos ganado la guerra (2007) escrita en castellano. Contrariamente a las escritoras precedentes, Tusquets escribe desde el punto de vista de la burguesía franquista, por lo que la suya es una visión única dentro de este estudio y plantea la complexidad de la Barcelona de los vencedores y de los vencidos desde el punto de la burguesía en el poder. Es también la pertenencia a esta clase burguesa alta lo que marca la diferencia lingüística con las otras escritoras, ya que Tusquets escribió todas sus novelas en castellano. En este capítulo, analizo la visión de Barcelona a través de la narrativa autobiográfica de Tusquets y demuestro la importancia de Barcelona no solo como su ciudad sino también como parte de su identidad. Con este género, el espacio urbano barcelonés que describe la autora marca la organización de la narración y a través la memoria de los lugares se estructura su vida y su libro, ya que la escritura autobiográfica de la autora es una búsqueda identitaria con la ciudad condal y con su familia. A continuación, basándome en diferentes teorías sobre los libros de memorias, demuestro que se establece la relación memoria/ciudad como fundamentos de las descripciones de los espacios como espacios de memoria y establezco también la diferencia entre el proceso narrativo y memorial de Tusquets y el de Montserrat Roig en Dime que me quietes aunque sea mentira. Si para Tusquets Barcelona es memoria autobiográfica, para Roig, Barcelona está vinculada a su pasado histórico (desde la Edad Media al siglo XX) que se reconstruye a través de lo imaginario y de lo real. Para ella, Barcelona debe verse como un "personaje testimonio" tanto por lo que se refiere a su propia historia., como en lo que concierne a la historia de las mujeres. En esta última parte de mi estudio, me centro en la división política y social que se refleja en la 
topografía de la ciudad y trato de demostrar la importancia de los espacios urbanos dentro de la estratificación de la sociedad. Finalmente, sin pretender resolver la polémica, planteo el problema de la narrativa en lengua castellana dentro del contexto de la literatura catalana. El hecho de que Tusquets escriba en castellano cuestiona su pertenencia a la literatura catalana e introduce el debate sobre la definición y características que debe darse a la literatura en castellano producida en Catalunya.

Mi trabajo muestra solamente la punta del iceberg de un fenómeno literario que exige un estudio más amplio y detallado, y que por lo mismo requiere de un tiempo y de unas posibilidades de investigación de las que carezco en el momento presente. Con todo, espero haber podido dar idea de la riqueza del material a analizar, el cual, quizá en un futuro cercano, pueda desarrollar y perfeccionar debidamente, de tal manera que pueda convertir mi estudio en un manuscrito publicable. 


\section{Capítulo II}

\section{La fabricanta.Novel.la de costums barcelonines (1860-1875)}

La vida d'urbanizació havia transformat el barri, però encara havia fet més estralls en els costums i en el comerç. [...] Aquells magatzems apilotats on els sacs treien l'amo a fora, s'havien engrandit arreu, i l'olor de floridura s'havia tornat flaire d'era, i la llum entrava a les coves, i la blancor a les tenebres, i la netedat en aquells caus, i la vida moderna floria. (Santiago Rusiñol, L'auca del Senyor Esteve 172)

Dolors Amàlia Beatriu Monserdà i Vidal (1805-1919) fue una de las escritoras catalanas más importante de la primera generación, ${ }^{1}$ (primer cuarto del siglo XX). Esta generación de escritoras, poco estudiadas y descuidadas por la crítica literaria vigente, incluye también a Palmira Ventós (1858-1916), que firma sus escritos Felipe Palma; Carme Karr (1865-1943); Catherine Albert (189-1955), que usa el nombre de Victor Català, y Maria Domènech (1877-1955). En La condició de la dona en la narrativa femenina catalana, Anne Charlon considera que para todas estas narradoras el hecho de escribir representa en sí mismo un acto de rebeldía ya que osan enfrentarse a la hostilidad social y al machismo. Para Charlon, las mujeres que se atreven a escribir bajo su verdadero nombre son las militantes feministas ya que "el sòl fet d'escriure significava un compromis, un acte de rebel-lia, una transgresió.”(45) Transgresión que Monserdà y 
otras escritoras de su generación promueven al crear y publicar en una revista semanal titulada "Or i grana."2 Efectivamente, estamos ante un verdadero acto de atrevimiento, ya que como lo señala con triste ironía Maria Aurèlia Capmany, la mujer no tenía el derecho de escribir sin el permiso de su esposo, "no podrà publicar escrits ni obres com a autora o traductora sense permís del marit" (El feminisme a Catalunya 45). En efecto, Monserdà, quien se dedicó al teatro durante la década de los setenta, tuvo que abandonarlo porque a su esposo no le parecía bien que una mujer escribiera obras de teatro y tuvo que esperar hasta la muerte del marido para reanudar esta actividad.

En los años sesenta, antes de escribir teatro, Monserdà publicó poemas, artículos y narraciones y, en la década de los setenta, empezó a escribir artículos en publicaciones de mujeres. Sus seis novelas aparecerán bastante más tarde, La Montserrat, (1893), La familia Asparó, (1900), La fabricanta, (1904), La Quitèria, (1906), Del món, (1908), Maria-Glòria, (1917), Buscant una ànima, (1919). Estos relatos casi siempre tratan de la vida de las mujeres en una Barcelona en constantes cambios debido a la industrialización de la ciudad. Monsardà escribe su primer libro a los 48 años por lo que el mundo de su novela es la creación de una mujer adulta que ha presenciado $y$ ha vivido la transformación de Barcelona.

En sus textos nos ofrece la visión femenina de sus experiencias personales, nos habla de los espacios urbanos interiores y exteriores, así como de la vida social y privada de algunos barrios barceloneses de su época. Por su producción novelística, Monsardà se perfila como unas de las primeras autoras catalanas, de hecho, Patricia Gabancho, en su estudio La rateta encara escombra l'escaleta, establece que Monserdà no sólo fue una novelista, sino que fue la primera escritora catalana: "Fins a l'entrada en el món literari 
de Dolors Monserdà, una de las donas mes actives i definitòries del feminisme català de l'època, no s'escriuen novel.las a Catalunya" (48). Sin embargo, a pesar de esto, el mundo de las letras no parece hacerle justicia y sorprende la escasez de investigación y de crítica literaria que se ocupa de su obra. Algo que refleja la autoridad literaria patriarcal que ha dominado en las letras catalanas hasta bien entrado el siglo XX. En su tesis, Dones $i$ ciutat a la Barcelona del segle XX: una anàlisi geográfica a través de la literatura (2000), Pepa Edo i Benaiges explica que la introducción del escenario urbano en la literatura catalana ${ }^{3}$ fue muy lenta por lo que contamos con pocos trabajos sobre la novela urbana catalana, en comparación con el gran número de estudios sobre novelas urbanas europeas o estadounidenses del mismo periodo.

En realidad, casi no hay trabajos que se dedicquen al estudio de La fabricanta como novela urbana y, aún menos, sobre la experiencia concreta femenina en la vida urbana al final del siglo XIX. Con el siglo XX, y la creciente toma de consciencia de autoras, Monserdà empieza a verse mencionada en muchos trabajos que tratan de recuperar una literatura femenina catalana. Maria Aurèlia Campany, Monserrat Roig, Patricia Gabancho, Anne Charlon, entre otras, le rinden homenaje reconociéndola como una importante escritora catalana. Ahora bien, de manera general, Monsardà sigue siendo una autora poco conocida y estudiada. Uno de los estudios más completo y extenso es la tesis de Pepa Edo i Benaiges, anteriormente mencionada, quien dedica su primer capítulo a un análisis detallado de La fabricanta, a la que considera primera novela urbana catalana escrita por una mujer. Es justamente el testimonio que encontramos en la novela de la vida barcelonesa, el que me interesa comentar con mayor profundidad, pues tenemos en esta obra datos valiosísimos para conocer, entender, establecer y recuperar la 
vida de las mujeres desde la perspectiva de una de ellas. Como he apuntado anteriormente, La Fabricanta abre paso no sólo a la novela femenina, sino también a la novela femenina y urbana en Cataluña. Monsardà se atreve a dar la visión personal de su ciudad y, a través de su escritura y de su mirada, Barcelona se nos plantea como mucho más que un telón de fondo, ya que supone tanto los límites geográficos de la novela como el cuerpo del texto.

La fabricanta recrea los años más representativos de la Barcelona de la segunda mitad del siglo XIX, es decir, los de la industrialización, desarrollo y crecimiento económico que la transformaron hasta en un nivel geográfico cambiando para siempre el centro de Barcelona y haciendo que la aristocracia y la vieja burguesía dejasen Ciutat Vella ${ }^{4}$ para mudarse a l'Eixample ${ }^{5}$. Una mudanza que experimentó la misma Monserdà ${ }^{6}$ en su propia vida y que ella extiende a los personajes de su novela.

Creo necesario subrayar que la historia de La Fabricanta sólo es posible en el contexto de la Ciudad condal, pues ninguna otra ciudad del Estado español a finales del siglo XIX y principio del siglo XX, vivió, como sucedió en Barcelona, la evolución socio económica que suscitó la Revolución Industrial del siglo XIX. En Catalunya, Barcelona se convertirá en "la fábrica" del Estado español siendo la capital de la industria textil (sobre todo en lo que se refiere al algodón y la lana). Este impacto en la sociedad producirá los nuevos moldes del mundo moderno con grandes cambios en los campos políticos, sociales, económicos y artísticos. Como consecuencia de estos progresos, la burguesía se impondrá en Barcelona como fuerza económica y política e irá fortaleciéndose hasta lograr controlar no sólo el poder político y económico, sino también el ámbito cultural, influenciando de este modo al mundo literario. Un fenómeno lógico y 
comprensible puesto que en ese momento la literatura era escrita por y para la burguesía, siendo un ejemplo bien claro de este fenómeno el caso de Monserdà.

Sin embargo, para mejor entender la emergencia de la pequeña y mediana burguesía, es necesario recordar que la gran burguesía catalana prefería invertir en la agricultura, en las finanzas y en sectores que exigían grandes capitales, como, por ejemplo, la construcción de la red de ferrocarriles. No obstante, como veremos en $L a$ fabricanta, las primeras fábricas textiles dispusieron de pequeños capitales y la industria catalana naciente se basó en capitales familiares, financiados por antiguos artesanos o dueños de manufacturas. Este contexto histórico social es primordial para situar la novela y entender la evolución de la protagonista, así como la del negocio de su familia, pues la saga familiar que nos propone Monserdà ilustra perfectamente el gran salto económico que permitió el paso de una economía artesanal a una economía industrial. De hecho, la autora publicó su libro en 1904, pero sitúa los hechos de 1860 a 1875, porque este periodo es justamente cuando Catalunya se estaba convirtiendo en la zona económica industrial más importante de todo el Estado español. Asimismo, la transformación al final de la novela del taller en el barrio de Ciutat Vella en dos fábricas una en Sants ${ }^{7}$ y la otra en S.Martí de Provençals ${ }^{8}$ alude a la transformación de los talleres urbanos en las grandes fábricas situadas ya en las afueras de la ciudad.

Como es bien sabido, la ciudad es un tema recurrente en la literatura, a tal efecto, en The image of the city in modern literature, Burton Pike afirma que "[s]ince there has been literature, there have been cities in literature" (3). Sin embargo, se considera que fue Charles Baudelaire quien, a mediado del siglo XIX fue el primero en entender y desvelar la importancia de la poética de la ciudad en su cotidianidad y como espacio de la masa 
humana. A Baudelaire le fascinaba ese "grouillement de gens dans le Paris d'Haussman, " y en su poesía, trata de trasmitir ese movimiento, ese instante que hace el momento efímero, en el medio de la inmutabilidad de las piedras. Como lo expone Benaiges: "El plantejament de la poética de la ciudad es troba directament relacionada amb la viviència o experiencia subjetiva del fet urbà i dels seus caràcters. Únicament en el marc de la ciutat viscuda es pot entendre la poética de la ciutat" (326). La "ciutat viscuda" y la cotidianidad son pues palabras claves para analizar la novela de Monserdà, por un lado, porque las historias que se nos relatan son fruto de la cotidianidad y, por otro lado, porque la "ciutat viscuda" es el texto mismo de esa novela, en el que la escritora resalta la presencia y la importancia que la mujer tiene en la transformación y el desarrollo de la nueva ciudad burguesa. A tal efecto, no me parece arriesgado afirmar que con La fabricanta Monserdà hace de la ciudad una entidad textual que supondrá el punto de partida de la obra de autoras como Maria Aurèlia Capmany, Monserrat Roig y Esther Tusquets. Todas las protagonistas de las novelas de estas autoras pasearán por las calles de Barcelona, en diferentes momentos de la historia siendo condicionadas y limitadas por las normas sociales del tiempo en el cual viven, así como por las restricciones "geográficas" de género y clase social.

Como he mencionado anteriormente, La fabricanta tiene lugar en Barcelona en el barrio de Ciutat Vella, rebautizado hoy en día con el nombre de barrio de la Ribera. Estamos en los años de la industrialización textil, durante el periodo de la primera fase de la urbanización de l'Eixample, que corresponde también al del cambio social que hará que la burguesía y el proletariado barcelonés aparezcan como clases ascendentes. Antonieta Corominas, la protagonista, es una joven huérfana, hija de manufactureros. 
Más bien fea que guapa, Antonieta vive con su hermano Josep, encargado del negocio familiar, una pequeña industria textil, hasta que se enamora de Pere-Joan Grau, un muchacho de condición social inferior con el que, a pesar de la oposición de su hermano, se casará ayudada en sus propósitos por su padrino, el capellán Vicenç y por la hermana de éste, la senyora Angeleta. A su vez, Josep se casa con una prima suya, la bella Florentina, hija de la posesiva tía Madrona. Florentina mimada por su esposo, que la cubre de lujo y le consiente todo tipo de caprichos, es el prototipo de la esposa insatisfecha presente en muchas novelas de la época.

A partir de estos matrimonios, el entorno social de las dos parejas cambia. Josep, que aspira a convertirse en un gran burgués, trata con desprecio a Antonieta y, empujado por una esposa ávida de dinero que padece de "bovarisme," deja los negocios e invierte en la bolsa. Mientras tanto, gracias a la inteligencia y visión emprendedora de Antonieta, de su tesón y de su trabajo, ella y su esposo crean una gran empresa a partir de los viejos talleres heredados del padre de Antonieta. La novela muestra la evolución de las dos parejas durante estos quince años, confrontando la degradación amorosa y el humillante fracaso financiero de Josep con el éxito matrimonial y empresarial de Antonieta. Sin embargo, como Antonieta no sólo es inteligente, sino también noble, obediente y generosa, el final de la novela tendrá un desenlace ideal, pues Antonieta logrará salvar a su hermano de la ruina sin herir el amor propio de su marido y sin tener que acudir al capital familiar.

A simple vista, el relato parece ser el elogio del trabajo y de la diligencia en las amas de casa, pero con el título de la novela intuimos que "el ángel del hogar" ${ }^{10}$ que nos ofrece la autora con el retrato de Antonieta aspira a algo más que a cantar las virtudes de 
un ama de casa típica. Una lectura más detenida nos revela que Monserdà acude a la literatura para denunciar discretamente la condición femenina, en particular la de la mujer burguesa en la sociedad patriarcal a finales del siglo XIX y principios del siglo XX. De hecho, resulta evidente que, sin que nos encontremos ante un texto explícitamente feminista, la realización de Antonieta como individuo trasciende el ámbito doméstico superando los deberes que el discurso patriarcal asigna al ángel del hogar. El mensaje es claro e inequívoco, la mujer se define ante todo como esposa y como madre pero, su persona resultará incompleta sin una realización profesional y un reconocimiento social.

Por supuesto, la reivindicación del rol público de la mujer que Monserdà expone en su novela debe comprenderse dentro de los cambios sociales generados por la industrialización. La sociedad barcelonesa se veía obligada, metafórica y literalmente, a seguir la velocidad de las máquinas que aceleraban el apacible ritmo de una ciudad todavía provinciana y tradicional. Así pues, en esa Barcelona en vías de industrialización, las mujeres ${ }^{11}$ de clase baja trabajaban cada vez más fuera del hogar, incorporándose al espacio masculino de la producción sin dejar el de la reproducción. Creo pertinente, aquí, aclarar que el espacio urbano no es solo un cuadro físico que genera prácticas asimétricas entre los sexos, sino también un código de vida edificado para asumir el rol de guardián y promotor de las normas dominantes. Al mismo mtiempo, esas normas, hacen del espacio, un relevo ideológico. Si damos ese "poder" al espacio tenemos que referirlo inexorablemente a las estructuras sociales y culturales a las cuales pertenece. Por eso, es importante reiterar que la lectura de esa novela está geográfica, histórica y sociológicamente circunscrita. 
Una ideología que la protagonista de Monserdà transporta al espacio de su casa convirtiendo el espacio del trabajo o de la producción en el mismo espacio que él del hogar. En el mundo de Antonieta, a pesar de su trabajo como directora de fábrica, no existe la división interior/exterior. Esta situación que nos presenta la autora es una manera de disfrazar su reivindicación del derecho al trabajo de la mujer, pues en una época donde sólo salían de casa las obreras o los hombres, su protagonista logra trabajar sin transgredir el orden patriarcal establecido. De este modo, en el relato de Monserdà, al desarrollarse la acción en el ámbito espacial del hogar y siendo ese el mismo que el del lugar de trabajo, la casa se convierte en el espacio urbano por excelencia sin que Antonieta deje de cumplir con su "deber espacial" de ama de casa. Esas representaciones se oponen a lo tradicional ya que, de manera general en la literatura urbana, el aspecto más descrito es el exterior por ser el espacio de los hombres y predominar en la literatura la perspectiva masculina. Monserdà rompe con esa tradición y nos deja un testimonio valioso que responde a lo que la autora Monserrat Roig reclama cuando dice que "para saber cómo fueron las casas, los interiores, necesitamos más memorias escritas por mujeres" (Dime que me quieres aunque sea mentira, 127).

Ante todo, Monserdà nos describe primero la vida de soltera de Antonieta con sus escasas salidas y su rutina doméstica. Sale sola para ir a la iglesia (San Pere) muy temprano por la mañana: "Preocupada amb lo pensament de cumplir amb les seves obligacions religioses, tocaven dos quarts de cinc del matí, quan la noia Corominas, vestida amb trajo d'orleans negre i mantonet de punt de reixa, pujava per las escales de la seva parròquia portant en ses mans lo devocionari[...]" (69). Los domingos se dedican a las visitas a casa de su padrino y después a casa de su tía y prima y, en verano, a los 
conciertos de la Euterpe. Cuando se trata de diversiones, solo tiene una, los conciertos de la Euterpe, a los que asiste siempre acompañada de su tía y prima porque: "A en Josep Corominas no li havia semblat bé abonar-hi a la seva germana, reduint sa complacència a deixar-la anar a l'estui als concerts de l'Euterpe, única diversió que freqüentava" (57). Los conciertos terminan de noche, lo que hace las calles aún más peligrosas para las mujeres, por eso casi siempre Josep Corominas viene a buscarlas. Esa tercera dimensión que conlleva la noche es una limitación temporal que se añade a la limitación espacial y que se convierte en otro espacio prohibido y amenazador para las mujeres. Cuando Josep no puede ir a buscarlas, la prima se queja: "Mira que haver-nos-en d'anar totes soles, amb aquesta fosca, ¡i tan lluny!... (49) y su madre está furiosa porque tienen que: “[...] emprendre la baixada a la ciutat pel desert i fosc passeig de Gràcia” (50). La noche, por su oscuridad, expone la mujer a todos los peligros y convierte la ciudad en un nuevo espacio prohibido para cualquier mujer de buena familia.

Para Antonieta, su casa, el espacio más importante de su vida, es el entorno limitado de la cotidianidad. De soltera vive "al primer pis d'una rònega casa situada en lo carrer Mitjà de Sant Pere [...] en lo menjador, tan sols obert per l'esquifida finestra del celobert $[\ldots]$ en l'esquifit balcó de la sala del davant...”(53). De la casa en sí, nos dice poco, pero nos ofrece una descripción bastante detallada del balcón. De hecho, la importancia del balcón se refleja en los detalles de la descripción, por ser su lugar favorito y por el valor sentimental que posee en su vida. Durante su celibato, el balcón será uno de los espacios más reveladores en la vida de Antonieta y el que le permita lograr su meta amorosa. Además, tiene un significado específico para la mujer catalana, ya que, como dice el refrán popular: "Dona balconera, dona mal feinera." Un proverbio 
que juzga y condena la mujer que se asoma a esa salida del ámbito doméstico que era entonces el balcón. No obstante, si lo tomamos al pie de la letra, vemos que aquí también Monserdà deconstruye el discurso patriarcal, ya que Antonieta es muy trabajadora e, incluso en el balcón, sabe encontrar el camino para su futuro. Mientras es soltera, el balcón, como espacio abierto, simbolizará la libertad por su emplazamiento arquitectural. Como señala Monserrat Roig, el balcón representa la libertad, si bien históricamente, es el espacio doblemente "espía" donde la mujer puede ver sin ser vista, pero también donde puede dejarse ver. Para Antonieta, el balcón será una herramienta primordial en su vida sentimental y, en cierto modo, marcará su futuro profesional. Es donde trabaja y cose, pero también, haciendo del balcón una "ronda" invertida, donde elige y corteja al que será su futuro esposo. Pere-Joan pasa por la calle porque es su camino para llegar a su casa y es Antonieta, quien desde su balcón "ronda" a su enamorado y se aprovecha de ese trayecto cotidiano e inocente del hombre para conquistarlo.

Por supuesto, el balcón es también el espacio donde Antonieta pasa su tiempo libre, su fuente de placer cuando es soltera, pero al que compara con un féretro que, paradójicamente, le daba un poco de vida a su existencia aburrida y sin alicientes: “ [E]n Pep se'n pujaba a dalt o anava a donar un volt per la ciutat, mentres la noia, en los mesos d'estiu o primavera, es prenia el luxo d'una estoneta d'esplai en l'esquifit balcó de la sala del davant [...] En aquell reduit terreno de vuit pams de llarg per tres d'ample, quasi l'espai d'une caixa de mort, l'Antonieta hi disfrutava tots los seus esbarjos dels dies feiners" (53). Asimismo, el balcón también tiene una importante relevancia afectiva, pues supone un pedazo de jardín para sus plantas y del que también brotan sentimientos y emociones, ante todo por el cariño que le tiene a su jilguera, que tiene enjaulada en el 
balcón, y, después, por su amor para Pere Joan. La similitud de la jilguera en la jaula con su propio encierro, es evidente, sin embargo, pienso que más que la falta de libertad y que la estrechez del balcón, la verdadera analogía reposa en el sentimiento de soledad que comparte con el pájaro. "Acabades les falagueries a les flors, venien les de la cardenera. $[\ldots]$ Antonieta es quedarà sense tenir al món cap amiga que l'estimi tan com tu! [...] ¿no et canses mai d'escoltar les coses que no puc explicar a ningú?.¡Tampoc tu no saps a qui contar les tevés![ ...]¿No ho trobes, que el món és ben trist? (53-54).

Es preciso aquí notar que esta tristeza contenida que nos da el texto, es perturbadora porque no corresponde ni al optimismo de la protagonista ni a su personalidad. Creo que aquí, todo lo que no llega a decirnos la autora, debido a las limitaciones sociales de su tiempo, nos lo dicen sus silencios, con los que nos hace sentir sus frustraciones. Como afirma Anna Caballé al hablar de la literatura femenina: "Hay que leer entre líneas, restaurar la elocuencia de muchos silencios, reconsiderar el valor de las cosas dichas para comprender las dimensiones reales de una identidad (históricamente) silenciada y marginal” (112). Es exactamente eso, lo que está inscrito en el texto sin ser escrito, el aburrimiento de su vida de soltera ritmada por las pocas salidas sociales. La soledad presente durante las comidas a pesar de la presencia de su hermano, quien se queda siempre callado y que sólo abre la boca para quejarse de ella. Y sobre todo, el balcón, cuya primera descripción estremece, "casi l'espai de una caixa de mort," y en el cual canta la jilguera "alegre," pero sola y encerrada. Incontestablemente este pájaro enjaulado es la proyección no sólo del encierro de Antonieta, sino también de su soledad y el parecido es deliberadamente incuestionable. De hecho, es importante establecer la relación estrecha que existe entre encierro y soledad, lo que Antonieta 
expresa hablando con su pájaro: “ ¡Encara que tu t'estàs tota sola i refiles amb una alegría...!"(54) Es el "encara" aquí, más que nada, lo que devela el verdadero sentimiento de abatimiento que acompaña su vida.

Su hermano sale a divertirse por la ciudad, pero ella, se queda dentro y sola. Ahora bien, el mundo de a fuera, público y abierto, es él del hombre, el de la calle, de la gente, en una palabra, de la sociedad. El mundo de dentro es un espacio limitado e aislado; es el mundo doméstico y sin movimiento. El mundo de la mujer es ese espacio doméstico y, por lo tanto se encuentra encerrado entre cuatro paredes, pero irónicamente, pocas veces es un espacio privado. Sin embargo, dentro del microcosmos de su casa, el espacio de Antonieta es el balcón. Un espacio que no está dentro, pero tampoco fuera del hogar, es como un lugar que no existe verdaderamente, pues de cierta manera flota, entre cielo y tierra o mejor dicho entre dos espacios, el exterior y el interior. Ahora bien, no debemos dejarnos llevar a errores, los cimientos, las bases del balcón vienen de adentro y es parte de la casa por lo que podríamos decir que es como un pedazo de libertad prestada y efímera. Una pretendida apertura que no hace sino recordarnos que en la sociedad patriarcal la mujer es un ser sometido, domesticado y con el dogal puesto, para el que el balcón es el límite de su correa.

A pesar de la monotonía de su soltería, Antonieta no hace del matrimonio una prioridad y rehúsa casarse con el señor Ramon por ser viudo y tener muchos hijos, pues como decía su madre: "[E]l casar-se amb un viudo amb fills era anar a fer victimes o a ser-ne [...] No, no, casar-se per casar-se no ha sigut mai la meva aspiració." (97), en consecuencia, Antonieta termina casándose a los 27 años y el matrimonio no cambia mucho su vida, o mejor dicho, su rutina. Sigue yendo a la iglesia y de compras, aunque 
nunca a comprar la comida, pues la mujer burguesa nunca se aventuraba por los mercados, eso era cosa de criadas. Seguramente que Monserdà, tampoco los conocía por ser unas de las fronteras más respetadas de la clase burguesa. Del lado de las diversiones, no menciona ningún tipo de espectáculo, sólo la gran salida en el día de "Divendres Sant.” Podemos deducir que la clase social y el género son los factores más significativos dentro de la vida cotidiana de la época. La mujer se resignaba a los límites de su barrio y dentro de las limitaciones del género femenino, la clase social alta tenía más diversiones y conocía más lugares por el tiempo y el dinero que disponían.

Sin embargo, una vez casada, el balcón ha cumplido su propósito y se ve despojado de su función primordial. Con la transformación de la casa y la mejora de sus capital el espacio privado pasa a ser el oratorio que, contrariamente al balcón, está dentro de la casa, es un lugar pequeño y con poca luz, pero que ofrece paz e invita a la introspección: “[A]nà a tancarse a l'oratori [...] Reclosa en aquell reduït espaï tan sol il.luminat per un dels ciris de l'altar, encès per a llegar en lo devocionari, l'Antonieta féu lo examen [...] en donar gràcies a Déu pel gran seguit de beneficis amb què l'havia afavorida" (239). Así vemos que, después de varios años de casada, Antonieta elige como lugar propio su "oratori" para recogerse, pensar, leer sus lecturas favoritas, El Año Cristiano, La Revista Popular, i Las Madres Católicas d'en Roca i Cornet (235), y darle las gracias a Dios por todo lo que logró. De la misma manera que el balcón reflejaba su estado de ánimo, el oratorio es la proyección de una Antonieta serena y en paz consigo misma.

Antonieta es una madre y una esposa ejemplar, que agradece a Dios su felicidad, sin embargo, como ya he señalado, la novela hace más hincapié en su papel de 
"fabricanta "que en el de "ángel del hogar". Escribo entre comillas el apelativo "ángel del hogar" porque quiero sugerir que, en el caso de Antonieta, encontramos diferencias fundamentales en la esencia misma del término. El sentido con que ampliamente se ha utilizado este término en la literatura del siglo XIX, designa a una mujer con todas las cualidades necesarias para hacer feliz a cualquier hombre; es decir, obediente, sumisa, callada, abnegada, pasiva, humilde, encantadora, piadosa, pura y domesticada. A pesar de toda esa colección de adjetivos, la definición se queda corta en lo tocante a la protagonista de Monserdà, pues Antonieta reviste todas las virtudes de este ángel hogareño, pero también ofrece mucho más convirtiéndose en una diosa de los negocios. Téngase presente que el apelativo ángel del hogar implica cierta pasividad y aceptación del status quo patriarcal, algo que es totalmente contrario a algunos aspectos de la personalidad de Antonieta. No olvidemos, que osa enfrentarse a su hermano, que le desobedece y que se casa con Pere -Joan sin dote y sin dinero. Es importante, aquí, señalar que, en Catalunya, la mujer heredaba y disponía libremente de una parte de la herencia legalmente. Por eso, a pesar de la oposición del hermano, la herencia sigue perteneciendo a Antonieta, inclusive una vez casada. Por lo que, las rebeldías de Antonieta se dan en un contexto que dejan bien claro que no estamos ante una romántica arrebatada, sino ante una mujer que se rebela ante los dictámenes del patriarcado a sabiendas que, hasta cierto punto, la ley la ampara en sus decisiones. Creo que, intrínsecamente es una mujer de carácter y de negocios, y que frente a los problemas económicos y, hasta sentimentales, siempre es ella quien encuentra la solución, mientras que su marido tiene un papel de ejecutante. Sin ninguna duda, Antonieta supera a su 
esposo en el mundo de los negocios y del razonamiento y sus decisiones son fundamentales para el desenlace feliz de la historia.

La prima de Antonieta, la guapa Florentina, tampoco es un ángel del hogar, en ella tenemos más bien la figura del ángel caído, o mejor dicho del que propicia la caída de los hombres. Desde el principio, las dos primas se oponen en todo, tanto en lo físico como en lo moral. Antonieta es más bien morena, no es guapa y no es presumida, Florentina es rubia, muy guapa y coqueta, la imagen del ideal de la mujer burguesa, el trofeo perfecto que concuerda admirablemente con el éxito social. Sin embargo, tanta belleza, no hace de Florentina un personaje positivo, todo lo contrario, se nos la describe como un ser superficial y materialista, a la que su adicción a la literatura romántica ha deformado su capacidad de comprender las realidades del mundo y del matrimonio, algo que su esposo Josep Corominas, enamorado de la belleza de Florentina, es incapaz de ver. Pero Florentina, no sólo es guapa sino que también acudió a las mejoras escuelas, pues como señala la voz narrativa: "La seva tia, amb lo natural desig de que, si ella no sabia de res, la seva filla sapigués de tot, l'havia portada al col.legi de les germanes Andrions -lo que aleshores estava conceptuat com un dels millors de Barcelona [...]" (56). Desgraciadamente, en una época donde el analfabetismo ${ }^{12}$ era tan alto, sobre todo entre las mujeres, la percepción de esa educación se ve como un desperdicio ya que, según la voz narrativa, sólo sirvió para convertirla en una Bovary Catalana. El caso es que, Florentina, lejos de compartir las lecturas religiosas de su prima, se trastornó la mente leyendo novelas sentimentales como La Indiana, La flor de un día, La dama de las Camelias, Los misterios de París, El collar de la reina, Fernández y González. Estamos ante una crítica directa de Monserdà sobre la educación que recibían las señoritas 
burguesas por ser una enseñanza de lujo inútil, que no prepara para ningún otro tipo de ocupación que no fuera la de encontrar un marido. Sin embargo, una educación más práctica, como la de Antonieta, era más útil ya que le permitió ayudar en los talleres y administrar la casa. Carmen $\operatorname{Karr}^{13}$ critica precisamente esa educación, que constituye un tema importante de la época, un "criteri ideologic," prácticamente una razón de lucha. Paralelamente, el ejemplo de una buena educación se ve en la que recibe el hijo de Antonieta, quien asiste a los Pares Escolapis a media pensión, (una escuela modelo, según Karr, donde ella mandaría a su propio hijo). Otro modelo de educación negativo es el que da Florentina a sus hijos con la demoiselle que los educa en francés. De hecho, esta crítica que emite la autora corresponde a su mentalidad y la de las feministas conservadoras de principios del siglo XX con reivindicaciones de tipo social, como el derecho a la educación o al trabajo, más bien que derechos políticos.

De hecho, cuando Florentina llega a los 14 años, lo primero que hace su madre es presentarla en sociedad para que encuentre a un pretendiente y, como a los 19 años todavía no tiene novio, su madre decide llevarla a fiestas y diversiones puesto que casarse y tener hijos era considerado como el estado natural de la mujer. Como vemos, las diversiones se vuelven en un espacio de caza para encontrar a un marido, por eso Florentina va al Olimpo con su madre: "Feia dos hiverns que la senyora de Madrona i la Florentina estaven abonades a l'Olimpo, bonic teatret situat al carrer dels Mercaders, molt concorregut en aquella època per la classe mitja barcelonina, i més especialmente per la que habitava en aquella part de la ciutat" (57). También pasea por las Ramblas ya “[q]ue el dijous passat [Enrique y Dominguito] vos varen trobar a la Rambla i que us acompanyaren fins a la mateixa porta de l'escala" (49). Del mismo modo, hace muchas 
visitas, como era costumbre en la sociedad de la época. Con el relato de estas visitas, vemos como la burguesía utiliza los lugares públicos para exhibir a sus hijos e hijas y como estos espacios públicos están compartidos entre los dos sexos. No obstante, no nos engañemos, este espacio frecuentado a la vez por hombres y mujeres, nunca es un espacio neutro puesto que en esa sociedad los dos sexos tienen papeles asimétricos y no poseen la misma capacidad para dominar la estructura espacial en la cual se encuentran. Sin embargo, una vez casada, ya no hay problemas de pertenencia y de comportamientos espaciales y Florentina se aislará saliendo raras veces siempre acompañada de su esposo. $\mathrm{Su}$ vida de burguesa supone la reclusión en casa, donde ejerce sus dos actividades favoritas, soñar y leer.

En el retrato de Florentina nos encontramos con un tema que no es extraño en la literatura femenina de principios de siglo, los peligros de dedicarse demasiado a la belleza y al aspecto físico, de hecho, en la novela La muñeca $^{14}$ escrita por Carmela Eulate Sanjurjo, la protagonista parece ser el fiel reflejo de Florentina. Como lo subraya Charlon, Monserdà se va de cruzada contra la "done objecte" pintando a Florentina como una mujer coqueta, materialista y egoísta (28). Para las dos "muñecas" lo más bello viene de París, y para Florentina, el extranjero, es lo que posee valor. La luna de miel de Florentina transcurre en París, un viaje que se intuye como un peligro, pues esa admiración por París será parte de su perdición. Al igual que Barcelona para Antonieta, París, para Florentina, es mucho más que una ciudad, es una manera de ser y de pensar, una metáfora de lujo, literatura y futilidades. Cuando Florentina regresa de París, no soporta su casa y no piensa que pertenece a este mundo, se siente totalmente déplacé: “Això féu que, al retornar a Barcelona, la ideal núvia se sentís com estranyada de l’efecte 
de disgust que li produí la seva modesta casa de la plaça de Jonqueres, enfarfegada amb tot un mobilari comprat als ebenistes del carrer dels Banys" (194). Florentina expresa una vez más su desprecio para Barcelona cuando recibe su regalo de boda de la parte de su amiga francesa, Sofia, Florentina está llena de admiración frente a su buen gusto, pero Josep no sabe lo que es y Florentina indignada le dice: “¡Ai, Jesús! Bona sort que estem sols... Si hi hagués algú de fora casa se pensaría que baixes de muntanya... ¿Que no ho veus, que és una panera per a posar flors a la taula?...i Ai, Verge Maria, sembla que mai hages vist res!..(153). Aquí vemos que, para ella, la cultura y la exquisitez pertenecen a la cultura francesa, pero al mismo tiempo el materialismo que envuelve su mundo es algo artificial, casi ajeno a la realidad de Barcelona. Confía plenamente en el buen gusto de su amiga, por el hecho de que ella vive en París y es francesa, por supuesto, esta admiración se hace en detrimento del gusto y del modo de vivir barcelonés. No es una comparación anodina, no se habla de arquitectura, sino de la esencia de una ciudad, de lo que le es propio. En la novela, la visión de Barcelona es exactamente esto, la ciudad se convierte en un ambiente, deja de ser un paisaje para convertirse en un estado de ánimo que va más allá de sus parques y de sus paseos.

Florentina rechaza Barcelona, no se enorgullece del patrimonio nacional industrial y fuerza a su marido a salir de la empresa familiar, lo arranca así de su pasado, lo que conllevará su ruina. Florentina en ningún momento valoriza la producción de Catalunya, todo lo bueno viene del extranjero, incluyendo la lengua. Sus hijos tienen una institutrice francesa, Mademoiselle, dando así la espalda a la enseñanza y, a la cultura catalana. Tanto así, que llama Armand a su hijo en honor al amante de La dame aux camélias, Armand Duval, pero lo traduce al castellano, Armando. Así vemos que París encarna 
sobre todo el ambiente del mundo de las novelas en el que Florentina se encuentra sumida:

Les quatres setmanes que, una volta efectuat lo seu matrimoni, passà a París en contínua intimitat amb la seva amiga Sofia, persona que des de criatura se n'havia endut totes les seves admiracions i a la que les circunstancies acabaren d'idealisar, al tornar-la a trovar en sa casa, rodejada d'una societat tan diferente de la que ella havia vist i casada amb un home distingidament educat, que semblava complaure's en fer pública ostentanció de sa galantería envers la seva muller, acabà de convencer a la Florentina de l'existència d'aquell món que havia llegit i que, amb tota sa realitat, amb sos porpis ulls acabava de veure a París. (194)

Frente a esta imagen negativa de mujer y de esposa, se erige Antonieta como portavoz y testigo de una nueva mujer activa y emprendedora $\mathrm{y}$, por consiguiente, capaz de demoler el estereotipo que la ideología patriarcal ha forjado de las mujeres y transgredir los límites espaciales y sociales trazados para las señoras. No obstante, el "feminismo" de Monserdà es muy conservador. El catolicismo y sus prácticas eran muy importantes para ella y las presenta a través de Antonieta, pero se las niega a Florentina. Probablemente, el catolicismo de la autora es la causa de que haya una total ausencia de sexualidad en la novela, a pesar que se trate de las vidas y acontecimientos de dos parejas antes y después del matrimonio. La Bovary catalana no llega por lo tanto a engañar su esposo. Monserdà es una clara representante de la burguesía catalana, fuertemente católica y tradicionalista y tanto sus principios religiosos como su moral burguesa, así como el hecho de ser mujer en un contexto literario extraordinariamente puritano, 
imposibilitaban todo tipo de alusión sexual en su novela. Alusiones que, de haber pasado por su cabeza, su expresión literaria hubiera dado al traste con un texto en el que lo que se proponía era enaltecer el positivo protagonismo de la mujer en la sociedad catalana.

He creído necesario establecer las diferencias entre las dos primas, porque su pertenencia a distintos estratos sociales, determina el uso del espacio. Tanto la movilidad de Antonieta como la de Florentina, quien pertenece a una clase social más alta, es muy limitada. Al principio de la novela, se nos dice que Antonieta no sale mucho ya que no era conveniente que una mujer soltera saliera sola porque la sociedad lo veía muy mal. A su vez, Florentina nunca sale sola a pesar de tener una visión del mundo más abierta que la de Antonieta. De soltera siempre se ve acompañada de su madre y, de casada, de su esposo. Sin embargo, las mujeres de clase baja solían ir solas a trabajar (a las fábricas o mercados), aunque su entorno se limitaba generalmente a sus barrios. Por el contrario, la burguesa paseaba por más lugares, pero nunca lo hacía sola, tenía un conocimiento más grande de la ciudad, aunque la suya era una mirada acompañada. No conocían -y era imposible que lo conocieran-, la sensación de caminar solas por las calles. Sin embargo, Antonieta llega a salir sola, lo que nos indica la pertenencia a una clase social más baja, y no a una emancipación más grande, que la de su prima, ya que, como he señalado, ésta primera confería a la mujer un mayor grado de movilidad. De todos modos, a pesar de las idas y venidas de Antonieta, es de notar que la frontera es Ciutat Vella, y sobre todo, la Ronda de San Pere, que, según Benaiges "[D]ivideix la ciutat entre la part alta i el casc antic. Una part alta, encara no urbanitzada del tot però en què ja comença a viure un sector important de la burgesia catalana i a localitzar-se alguns espais de lleure per a la ciutadania, funció básica que en aquella època tenia el centre de l'Eixample.” (214) 
La novela nos da varios ejemplos de la movilidad de Antonieta que siempre son de carácter doméstico, por ejemplo cuando va a comprar su vestido de novia o la ropa para los eventos religiosos del niño, o cuando va a la iglesia. Siempre camina sola y cuando pide a su esposo que la acompañe a comprar la ropita para el niño que está esperando, entendemos que el suyo es un recorrido que ya había hecho sola, ya que sabe exactamente lo que quiere y donde encontrarlo: "[A]1 sortir de Sant Pere has de venir amb mi al carrer de la Boqueria per a veure una cosa molt bonica que hi tinc emparaulada i que se'ns emportarà molta estona. I d'alli hem d'anar al carrer de l'Hospital per a triarne un altre." (163) Por supuesto, su esposo se sorprende que le pida que la acompañe porque ese tipo de compras son cosas de mujeres, así que una vez más vemos que el espacio de los hombres y las mujeres está regido por los roles sociales de los géneros.

Me parece pertinente señalar que en la novela hay un fuerte contraste entre las salidas que Antonieta hace sola y las que hace cuando va acompañada de su marido. Es de notar que cuando anda sola, no hay ninguna alusión a la gente que está en la calle, como si caminara sola en una ciudad fantasma, sin embargo, cuando está con Pere-Joan, el 'Divendres Sant de l'any 1875, lo primer después de la restauració de la dinastía borbónica [...]"(176), ambos están rodeados por una multitud. Esta diferencia ilustra la relación que la mujer del siglo XIX tenia con el espacio público. El exterior, era un mundo ajeno y peligroso, la mejor manera de comportarse era de ignorar lo que pasaba a su alrededor y de alejarse de la vida social que la rodeaba. Lo mejor era caminar sin parar y saber dónde ir sin meterse con lo popular, es exactamente la sensación que nos da el texto cuando Antonieta habla de sus salidas domesticas. Sin embargo, cuando, pasea con su esposo hay un reconocimiento de la muchedumbre, de repente Barcelona se llena de 
gente y de movimiento: "La religiosa solemnitat de la diada era finida; però la gent $[\ldots]$ desde las iglésias féu via envers al centre de las Ramblas per a dirigir-se al carrer Fernando, que en un instant restà negre de cap a cap[...]' (179), o como lo cuenta Antonieta, "hom no se n'acaba de satisfer mai, de seguir iglésies; i la veritat és que en cap s'hi podía entrar, de tanta generació"(181) y en la calle Fernando: "Los passejadors caminaven tan apretats uns amb altres que les senyores sols lluïen los trajos de la cintura al cap $[\ldots] "$ " Esta "promiscuidad", en el sentido de cercanía física con los otros es posible porque las mujeres están con sus esposos, de no ser así, la situación sería amenazadora ya que el mundo exterior es visto como terreno peligroso e inapropiado para la mujer y se opone a la seguridad y la reclusión que caracterizan el hogar. De hecho, ese mismo día, hay un evento con la pareja Corominas que lo ilustra perfectamente, después de caminar por la calle Fernando, Josep y su esposa siguen por la Rambla, pero hay tanta gente que se ven obligados a separarse, y Florentina se vuelve una presa: "[A]profitaron aquella ocasió per a abocar a les orelles de la Florentina tot lo manossejat repertori de lloances amb què alguna homes $[\ldots]$ solen celebrar los encants de les belleses femenines.”(182). El caso es que, en el espacio público, el hombre es el que protege y a la vez el que incrimina a la mujer. Esta situación deja pocas opciones a la mujer y la que sale sola es aceptada en los lugares públicos por razones utilitarias (domésticas) pero, no puede de ninguna manera, transformarlos en espacio de socialización. Si transgrede esta regla, los espacios devuelven inmediatamente la sanción: mujer de mala vida. Antonieta entiende muy bien que el espacio urbano es un código de vida basado en una repartición desigual de los espacios asexuados y, no tiene más remedio que respectar estas normas impuestas por la sociedad. 
Con todo, Antonieta trabaja, de hecho, de todas las mujeres burguesas de la novela, ella es la única que trabaja por y para la fábrica. Las demás mujeres tienen la ocupación típica de las señoras burguesas en el hogar: coser, criar los hijos, asegurarse del bienestar de todos y ocuparse del servicio, ya que todas las casas tenían una criada o varias, dependiendo de la clase social, como en el caso de Florentina. No obstante, en el caso de Antonieta, a pesar de su trabajo, es importante notar que, en ningún momento, se menciona remuneración monetaria alguna, un salario sería admitir que trabaja. El negocio prospera y el matrimonio logra ascender a la clase alta burguesa, pero al final, cuando se trata de ayudar a su hermano, ella no tiene dinero, lo único que tiene es una casa. Esto demuestra que el trabajo reconocido y legítimo de Antonieta es el de ama de casa, el otro, es más bien visto como una ayuda familiar, porque, de hecho, la fortuna pertenece a su esposo por ser hombre. Naturalmente, la realidad no corresponde a la proyección tradicional masculina y Antonieta no puede percibirse como un ama de casa típica porque también es una empresaria y por lo tanto no puede realizarse como persona sin trabajar en los negocios. En consecuencia, la casa/taller es para ella fuente de inspiración, creación y procreación. Con la protagonista de su novela, Monserdà ya nos da una imagen de lo que se verá evidente en la mujer a finales del siglo XX, la necesidad de realizarse profesionalmente. De hecho, el aspecto más interesante de la novela no es tanto que la protagonista sea la mujer y madre perfecta, sino el que sea una mujer de negocios excepcional con más aptitudes que su esposo y quizás hasta que su hermano. En el otro extremo de la escala social, las obreras, tienen por supuesto doble jornada, el trabajo de la fábrica, fuera de casa, y todos los quehaceres del hogar, una vez en ella. 
Sin embargo, esta doble carga de trabajos con las dificultades que eso implica no se menciona, la autora escoge la prudencia y lo omite totalmente. De hecho, en la novela hay muy pocas referencias a la realidad social de la clase obrera de la industria textil. Lo que resulta paradójico sabiendo que Monserdà fue una de las pocas defensoras de las condiciones de trabajo de las mujeres ${ }^{16}$ y que, en una de sus muchas conferencias declaró:

[A] Barcelona les dames de la noblesa, la rica burgesia no ha girat encara els ulls envers les infelices noies que - després de vuit a deu anys de costosos estudis, fets amb la digníssima il-lusió de guanyar-se honradament la subsistència, donant lliçons - lluiten desesperadament per obtenir una mesquina mensualitat; no s'hi han fixat, en les apremiants necessitats de les obreres de les fäbriques i de les fadrines d'ofici; no l'han vist encara, la infeliç dona que, nuats els pous, corba l'esquena, fixa la vista sobre una planxa d'acer, vertiginosament del matí al vespre, cus calçotets a l'inverosímil preu de "quince cèntims" de peseta, camises "a dotze", enagos amb farbalans i entredós "a vint-i- cinc"; i malgrat que amb tan irrisori preu cal que treballi sense descans, sense repòs, deu o dotze hores diàrias per obtenir un jornal que moltes voltes no arriba a la miserable peseta, la infeliç, sense pensar en el dany que amb sa folla competició causa a ses germanes de treball i ella mateixa, s'esforça encara per afegir a la feina un altre plec, un repunt més, un adorno nou, per que tal que la peça resulti mes vistosa; perquè l'industrial estigui content; perquè no arribi a ses orelles aquell esgarrifós; "no hi ha feina!" 
que l'aclapara, que l'esvera, perquè li representa la pèrdua d'aquella pesseta que espera per al mos de pa amb què ha de mantenir-se ella i a voltes els seus fills i amb què ha de pagar el lloguer del meravellós invent de la màquina de cosir, que àdhuc quan li fa guanyar tan “esplèndid”jornal, l'empeny a la tisi i a la mort. (57)

A partir de esta cita, entendemos que, lo que pide Monserdà, es más una protección que un derecho. Es la explotación de la mujer en general más bien que la de la obrera en particular, con lo que Campany considera propio del "lumpenproletariat," es decir, un proletariado femenino sin consciencia de su explotación. Para Capmany, Monserdà ejemplifica la típica visión burguesa: "La defensa de la dona obrera defensada en tant que dona explotada per l'home, no en tant que obrera explotada per l'amo o la mestressa, pot desembocar cap a una disfrassada filantropía que actuï amb els millors resultats contra l'obra sindicalista" (57). De hecho, esto es exactamente lo que describe la única escena de la novela sobre los obreros de la fábrica. En la casa/fábrica, hay varios pisos, uno, donde trabajan los hombres y otro, en el que se encuentran las mujeres. La escena se abre con un diálogo en el que las obreras subrayan la generosidad de Antonieta, pero una de las más ancianas regaña a una obrera de dieciocho años: “iSembla impossible que, després de lo que la mestressa va fer per ta mare en los sis mesos que va estar malalta, encara gosis a parlar d'aquest modo!..” (210). La muchacha replica “iJo et floc, gran mal se’n fa! ¡Per això està carregada d'unces i jo no tic a on caure morta!...” (210). Pero en vez de reconocerlo, las otras trabajadoras exclaman “ ¡Calla, calla, que escruixeix de sentir aquesta llengua!” (210), Con esto Monserdà afirma y elige quedarse del lado de la burguesía, por una parte, entiende que las condiciones de trabajo y de vida 
de las mujeres eran muy difíciles, pero por otro, deja bien claro que la solución no es una toma de consciencia política, sino un altruismo que en ningún momento ponga en juego su propio bienestar social. De hecho, Monserdà pide que la obra del feminismo se convierta en un movimiento de protección hacia la mujer obrera sin por ello ir en contra del orden social establecido.

En la misma escena, uno de los tejedores viene a recoger a su hija, pero las mujeres no han acabado porque Antonieta, les ha pedido que terminaran un trabajo. Aquí también, el hombre que vino a buscar a su hija está con un obrero más joven y se desarrolla una situación en la que la autora contrapone las voces de los obreros ante la explotación de los patronos: “¿I que voleu dir que no ens fa una bona obra de treure’ns la son de las orelles? - saltà vivament lo teixidor jove, encarant -se amb lo que acabava de parlar-. També hi estic jo, en que ja és hora de que ens comencem a treure'ns la llana del clatell, ¿Que no ens hem deixat explotar prou pels amos?” (212). Ahora bien, la reacción del obrero más viejo es de apoyo al status quo al exclamar: "[A]questos Centros que vos malmenen los quartos i l'enteniment?" (212). Este episodio será el único momento en toda la novela donde se hablara de los obreros de la fábrica y, merced al dialogismo con el que se presenta, si bien no supone un explícito ataque al sistema en el poder, hace patente el resentimiento del proletariado hacia la burguesía y afirma el concepto caritativo de Monserdà, según el cual la mujer burguesa debía de proteger a la mujer obrera.

En esa descripción de la casa/taller notamos que dentro de la configuración de los espacios de trabajos en las fábricas existe la separación de los espacios entre hombres y mujeres y el hecho de que cada género tiene su propio piso se presenta como algo 
normal. Primero, por la distribución del trabajo donde el hombre usualmente hacía las tareas más difíciles. Casi siempre, en los centros fabriles, donde el hombre tejía "[s]e sentía clarament lo tic-tac dels telers que funcionaven a la quadra del pis de dalt, a on treballaven los teixidors" (208) y la mujer hilaba o despuzaba o hacía canillas oyéndose “el moviment dels rodets al pasar los fils per la guiadora i d'aquesta a l'ordinador." (208). Segundo, porque la proximidad hombre/mujer atentaba a la moral dominante. Otro aspecto que no menciona la autora es la diferencia injusta de los salarios entre la mano de obra femenina y masculina, tampoco se denuncia, en ningún momento, la presencia laboral de los niños.

Otra gran paradoja en el texto es que la autora evoluciona en el mundo de la industria textil sin mencionar a las "xinxes" ${ }^{17}$ que fueron, una de los elementos más importante en el mundo obrero textil. Uno se pregunta ¿por qué Monserdà excluye totalmente a estas mujeres? Fueron víctimas de una doble explotación, por ser mujeres y obreras, y sobre todo, fueron una parte esencial de la Revolución Industrial por ser las protagonistas indispensables en el desarrollo del capitalismo industrial textil de Cataluña. En su libro, Dime que me quieres aunque sea mentira, Montserrat Roig las recuerda así:

¡Bien que conocía las "chinches” la calle! Las novelas populares de principios de este siglo, algunas anónimas, cuentan cómo vivían estas mujeres, las primeras proletarias de la Revolución Industrial: trabajaban desde las cinco de la mañana hasta las ocho de la noche, siempre bajo el ojo atento del mayordomo y el contramaestre, sin tiempo libre ni para respirar. Dicen, también, que no tenían tiempo de lavarse ni asearse, que 
no sabían que era el calor de un hogar, que no tenían ánimo para aprender nada porque el trabajo las extenuaba, pero que tenían el instinto de la rebeldía, porque cualquier cambio que llegara no podía ser peor que aquella vida sin dignidad. (145)

En ese sentido, Monserdà, nos da la visión de la burguesía porque, en definitiva, difícilmente se puede escribir desde otra perspectiva que no sea la propia. Ahora bien, no creo que Monserdà las silencie únicamente por ser burguesa, ya que estaba muy bien informada sobre las condiciones de vida deplorables de la clase obrera, sino por otras razones y esta omisión voluntaria señala con el dedo el ojo omnipresente de la autoridad androcentrista que dicta la buena conducta a seguir. Monserdà se ve obligada a escribir dentro de las limitaciones de su tiempo y género y, como observa Cristina Dupláa al hablar de la obra de Victor Català, ${ }^{18}$

Era evidente que la historia era una y la ficción era otra, totalmente inconpatibles en la Catalunya de 1917. La mujeres de aquellos años no podían ni matar a sus hijas, ni ser violadas en la literatura catalana, tenían que ser seres dispuestos a colaborar con el proyecto marcado por los hombres: en definitiva, tenían que ser una pieza más de un cosmos ordenado y equilibrado, que hiciera compatible la maternidad con el reformismo espiritual de todo engranaje ideológico de los estetas regeneracionistas de las obras de las primeras décadas del siglo XX. (77)

¿No se podría aplicar lo mismo cuando se trata de hablar del proletariado? El sistema patriarcal no aceptaba ni permitía que una mujer escribiera sobre lo que molestaba y, sobre todo, que se metiera en lugares no creados por ella. Pero al mismo 
tiempo, tampoco podemos olvidar, que toda esa miseria y explotación humana eran las minas de oro de la oligarquía textil y que la burguesía a la cual pertenecía Monserdà se beneficiaba de esta situación socio-económica, por lo que se comprende su silencio.

Por otro lado, Monserdà habla en varias ocasiones de las criadas, por ser parte del entorno doméstico y del esquema burgués de la época. Éstas, casi siempre son muchachas muy jóvenes y solteras, así que, a través de ellas, también vemos que la mujer de la clase baja, si es soltera, tiene que trabajar para poder sobrevivir. El salario de las criadas será el único mencionado en la novela: "Mossèn Vicenç i la seva germana Angeleta $[\ldots]$ ne tenien prou per a sostener los gastos d'una minyoneta de la Segarra a la que les amigues envejaven la sort de guanyar dotze pesetes mensuals [...]" (75). Pero la condición de solteras no se restringe a las criadas, y la novela también habla de la condición de soltera a través de Antonieta que, curiosamente, puede asumir el quedarse soltera, pero rehúsa el papel de tía y de vivir con su hermana y cuñada. El problema de las mujeres solteras era una realidad de la sociedad catalana cuando se escribe la novela, por eso Monsterdà defensa públicamente el derecho a la educación y reivindica el derecho al trabajo fuera del hogar para que las mujeres puedan vivir dignamente sin casarse o sin tener que hacerse monjas. Monserdà veía en el trabajo una opción positiva y liberadora para la mujer, donde podría encontrar su felicidad y su independencia económica.

De hecho, cuando Monserdà escribe, muchas de las mujeres que trabajaban lo hacían por necesidades económicas, pero en el caso de Antonieta, a pesar del aspecto económico, hay más que nada una satisfacción personal, una realización de lo que quiere ser. Para ella es un verdadero placer, y la autora utiliza una terminología sensual cuando 
describe su trabajo, sensualidad que no existe cuando describe la noche de bodas y que sorprende en este contexto: "[A]mb los ulls brillants, animat lo rostre, alegre el cor per semblar-li que retornava a l'època del seu antic regnat en aquells llocs [...] quan ses mans havien ja fruït prou estona amb lo goig que li produïa el tacte de les peces [...]" (207). No se puede negar que esto le dé vida, y que la relación que tiene con su trabajo sea una necesidad tanto física como mental.

A lo largo de la novela, Antonieta es una mujer llena de energía, de proyectos comerciales que asocia placer con el trabajo no doméstico. Representación totalmente contradictoria a la imagen proyectada por el patriarcado, donde el hombre es activo y por consiguiente, la mujer por ser diferente, diferencia que implica la inferioridad, es pasiva. Ahora bien, Antonieta tiene muchas otras características que los hombres consideran propias del sexo masculino, es productiva, racional, lógica, visionaria y segura de sí misma. El peso del mensaje de la novela reposa en esa habilidad "masculina" en una mujer, que sin embargo no es rebelde. Un buen ejemplo es cuando Pere-Joan se desespera porque las máquinas están invadiendo y cambiando la producción textil en Catalunya y, como ellos no las tienen, concluye que eso los llevara a la ruina, pero Antonieta reafirma su mentalidad emprendedora y visionaria con fuerza y, frente a la pasividad y desánimo de su esposo, encuentra la solución perfecta. En este cuadro se pinta un PereJoan desprovisto de imaginación, totalmente pasivo y vacío de energía, a su lado, se erige Antonieta con dos palabras: "En comprarem" (204). Es este ritmo de pensamiento y de acción que hace de Antonieta un modelo ejemplar de fuerza y perseverancia, ya lo dice ella: "En lo negoci, qui no arrisca no pisca. ¡Déu nos ajudarà! (205). 
El título de la novela (La fabricanta) ya nos sugiere que vamos a encontrarnos con la historia de una mujer que tiene una ocupación considerada tradicionalmente como masculina. El texto de Monserdà constituye pues una estrategia para expresar que, en el mundo del trabajo, los papeles son distribuidos por la actitud misógina de los que rigen la sociedad y no por leyes biológicas, como pretende hacernos creer el sistema patriarcal. Con todo, para afirmar su punto de vista, la autora parte del discurso patriarcal, mostrándonos que hay dos tipos de mujeres, las que, como Florentina, se pasan las horas leyendo o soñando o las que, como Antonieta, tienen capacidad para los negocios, pero son con frecuencia vistas como anormales y reprimidas por los hombres. Así, la capacidad empresarial y mercantil de Antonieta es vista como algo excepcional, casi como algo increíble, y obviamente menos valorada e importante que la de su esposo, quien no duda en impedirle que siga trabajando en la fábrica, como si su papel en la empresa familiar fuera secundario. "[E]n Grau, portat per aquest esperit d'orgull, gelosia o afany de superioritat propi en l'home espòs, de mica en mica, convençut de que amb sols haver-li dit: 'Descansa i disfruta de lo que t'has guanyat' quedava liquidada de sobres la gratitud de què es féu mereixedora [...]" (249). Sin embargo, Antonieta, lo tiene bien claro, y resume en pocas palabras los verdaderos motivos de su esposo: "esperit d'orgull, gelos, afany de superioritat." Aunque justas, estas palabras resultan sorprendentes en la pluma de una autora que no exhibía un feminismo draconiano, sino más bien conservador, por lo que no debemos de olvidar que esa crítica directamente dirigida al patriarcado no tenía el propósito de subvertirlo, sino meramente el de subrayar la injusticia de la realidad social y laboral de la mujer. Sería interesante, aquí, añadir que Pere-Joan, sin ser maravilloso, es uno de los mejores maridos que Monserdà ha creado en 
sus novelas, también el único que no muere en la historia. Según Charlon, "Monserdà tracta la figura del marit de manera que la lectora normal destigi el celibat per a tota la vida. De fet, para Monserdà, un bon marit és un marit mort, sobretot si ha tingut el bon gust de deixar a la seva vidua una renta tranquilitzadora" (La Condició De La Dona 37).

Es un poco desconcertante ver que, a pesar de su feminismo conservador y católico, Monserdà denigra a los hombres ya que, bien pensado, el hermano, Josep Corominas, exhibe los mismos defectos que los otros hombres. Sin embargo, las novelas de Monserdà siempre tienen protagonistas muy positivas, ahora bien, los maridos, excepto el de La familia Asparó, son egoístas y orgullosos, rasgos que reconocemos en el esposo de Antonieta.

A pesar de ese defecto del carácter de su marido, Antonieta le obedece, pero no por miedo, sino por deber y resignación, ya que para ella, como para la Iglesia Católica, la resignación es una de las grandes virtudes, especialmente en las mujeres y en los pobres. De cierta manera, tiene el poder, pero no es dominante, ni es calculadora, es ambiciosa no para ella misma, sino para la casa y la familia. No cabe duda que Antonieta tiene la virtud de la resignación, sin embargo, es con un tono crítico que compara la vida de la mujer burguesa a una vida ociosa y sin actividades, una vida sentada en la inmovilidad, una vida que relega la mujer a un adorno más de la casa viéndola: “com a planta paràsita entre els velluts i tapisseries"(206), el adjetivo parásita nos llega casi con violencia y nos da la visión bien clara no sólo de la falta de actividad, sino también de dependencia cuando ella fue la que heredó el negocio y quien lo mejoró. De hecho, esta palabra deshace y destruye de un solo golpe la identidad de la "fabricanta." Son dos entidades que se oponen porque, en una, se funda la imagen de la "fabricanta" siempre en 
movimiento, trabajadora y productora y, en la otra, la imagen, no de una mujer pasiva, sino de una planta parásita, objeto de decoración entre los otros adornos verticales de la casa. El cuadro pintado aquí es importante y adecuado, ya que las cortinas de terciopelo y las tapicerías eran parte de un interior burgués. Además, esta imagen refleja, por la palabra "velluts" cortinas espesas y tradicionalmente oscuras o por lo menos opacas, deteniendo el mundo de afuera o mejor dicho, guardando a la mujer dentro. Antonieta se ve así separada del mundo exterior, lo que expresa sin ambages a su esposo: "[J]a no li semblà bé que la seva dona continués treballant a la vista del public; i, protestant de que ja tenia dret al descans, la privà d'exercir los seus càrrecs" (206). Aquí, sin ninguna ambigüedad, la casa guarda a la mujer de la vista del público y las cortinas de terciopelo la protegen muy bien y con lujo de las miradas del mundo exterior. Como he mencionado anteriormente, Monserdà se sirve de la literatura para denunciar la subordinación de la mujer hacia el hombre, pero lo hace con mucho cuidado. En ningún momento en la obra pone en duda la autoridad y la soberanía de su esposo y nunca se enfrenta a él, ni siquiera habla del tema con él. Al final, el hecho de darle otra vez las riendas del negocio, no deriva de un "derecho," sino de la generosidad de su esposo de aceptar que Antonieta es una negociante nata. Notamos que es de modo muy tenue que condena la sumisión de la mujer, pero no llega a reivindicar claramente su independencia socioeconómica. Su retorno a la fábrica se debe a la generosidad de su esposo, si lo extendemos a una estructura social se convierte en una concesión, pero de ninguna manera en un derecho.

No cabe duda que el feminismo de Monserdà conlleva cierta ambigüedad, sin embargo, según Lisa Vollendorf, la lucha contra la desigualdad social es el punto de partida de la ideología feminista y es justamente este pensamiento que hace de Monserdà 
una de las primeras escritoras feministas en Catalunya. Ahora bien, la representatividad y la identidad de Barcelona están estrechamente ligadas a la imagen de Antonieta, de ahí que en esta proyección la condición de la mujer no pueda no ser representada. Por eso, en el paralelismo Antonieta mujer y Barcelona ciudad sobresale la sujeción a la cual, las dos, están sometidas. Eso es particularmente importante si consideramos que las dos siempre están sujetas a la mirada de la autoridad, (el marido/ Antonieta y Madrid (Barcelona) y estos dos poderes opresivos les dan cuerda hasta cierto punto, sobre todo por necesidad, pero las paran cuando sienten su propio poder y posición en peligro. La pertinencia de esta fusión se refleja más concretamente en la yuxtaposición textual de la novela con el cuadro no verbal de la historia de Barcelona, el cual subraya la necesidad intertextual entre el texto y la cultura del lector empujando la analogía a un doble nivel. Antonieta es oprimida por el sistema patriarcal y por el poder representado por Madrid. En ese sentido, incluimos en la lectura los acontecimientos históricos implícitos en la narración como la demolición en 1868 de la Ciudadela. ${ }^{19}$ fortaleza imponente y humillante que en la memoria colectiva barcelonesa siempre fue un símbolo de opresión y que, por lo mismo, refleja la represión de las mujeres y el dominio del patriarcado al cual están sometidas. De la misma manera, las murallas, mencionadas de pasada en el texto, eran un cinturón que apretaba, asfixiaba y encorsetaba la ciudad impidiendo su crecimiento, su desarrollo y su autosuficiencia, aquí también la analogía es directa: podría afirmarse que la mujer se siente apresada y restriñida en el corsé machista. La estrechura de las calles del barrio de la Rivera donde vive Antonieta engendra la misma idea de ahogo que acompaña la falta de libertad y la imposibilidad de ser. 
La relación personaje/ ciudad construida en esa novela revela el funcionamiento de la relación entre persona /ciudad en el mundo referencial. Así hemos visto como Antonieta está construida por Barcelona al mismo tiempo que ella la construye. Antonieta es Barcelona, no por su físico, sino por lo que más la caracteriza su trabajo, su energía y su nacionalismo, "Durante vingt-i-quatre hores, la nostra traballadora ciutat deté les rodes de centenars de màquines" (175). La ciudad se encarna en la figura de la protagonista cuando, por su lado, esa última adquiere su éxito gracias a su trabajo y a su mente emprendedora y la imagen de Barcelona se proyecta en Antonieta en la inagotable y fuerte energía de la cual rebosa. Es el mismo temperamento y visión, y Antonieta simboliza, tomando las palabras de Andreï Platonov, en Moscou heureuse, "un hogar central" ya que todo evoluciona a partir de ella y gracias a ella y de la misma manera Barcelona se fortalece como el "hogar de la patria".

Antes de seguir con Barcelona como ciudad de novela, me gustaría regresar al espacio doméstico y a la función que tienen algunos cuartos de las casas. Ya hemos visto el balcón y el oratorio en sus significados simbólicos, ahora es necesario hablar del concepto bajtiniano del cronotopo. Para Mijaíl Bajtín ${ }^{20}$ : "In salons and parlor the webs of intrigue are spun, denouement occur and finally this is where dialogues happen, something that acquires extraordinary importance in the novel, revealing the character, "ideas" and "passions" of the heroes"(65). Ya hemos visto que, con la mejora económica y el bienestar que logra la pareja Grau-Corominas, la casa cambia, pero no la función del "salón" que, en casa de Antonieta, será el "comedor," que es -y siempre ha sido- el espacio donde en los hogares de la pequeña burguesía catalana siempre se ha hablado de los negocios y que, en la novela que nos ocupa, substituirá al cronotopo del "salón". La 
última noche del año 1862 señala la importancia de las primeras ganancias del negocio y Antonieta quiere pasar cuentas de este primer año, pero Pere Joan quiere descansar: "¡Ai, no fill, no: això fóra un desorder!(...) Jo no sabria pas dormir, aquesta nit, si no deixà ben apuntat a la llibreta lo resumen de l'any.”(162). A lo largo de la novela, y sin excepción, este cronotopo del comedor será el espacio/tiempo generador de la acción de los negocios, es decir que será el espacio donde Antonieta decidirá alquilar la planta baja, comprar las máquinas y ayudar a su hermano con una destreza profesional admirable. De la misma manera, el comedor de la casa de su padrino constituye otro cronotopo, pero en él no se habla de negocios, sino de amor y es allí donde se ejecutarán todos los trámites para el matrimonio. Sin embargo, esos dos cronotopos, con escenarios dialógicos diferentes, pero sin ser excluyentes, no pueden intercambiarse y establecen la casa de Antonieta como el espacio de los negocios y la del padrino con el de los sentimientos.

Como ya he señalado, la prosperidad de Antonieta y Pere-Joan es paralela a la transformación que conoce Barcelona y a la revolución industrial que experimenta la ciudad. Sobre esa idea se cimienta la noción de pertenencia entre Barcelona y Antonieta. Barcelona es su territorio, el de sus padres y de su descendencia, es el locus classicus urbano de la industrialización catalana. Por lo que podría decirse que para Monserdà, Barcelona representa lo que Roma simbolizaba para Freud: "the primary emphasis in Freud's image is on the city as a continuum between the monumental past and his own present, between the dead and the living" (20). El pasado está aquí representado por el padre y el abuelo, y se concretiza transmitiéndose por los talleres y la casa. El abuelo estableció la primera piedra que permitirá la superación de los negocios de Antonieta. Ella vive en la casa de sus padres, que fue también la de sus abuelos, y en esos cimientos 
es donde elevará un imperio industrial. Siguiendo la misma idea, no es ninguna casualidad que el único hijo de Antonieta sea un varón, así la transmisión y la continuación se ven aseguradas. Es en ese mismo concepto que al final, Josep, regresa al negocio familiar, a sus raíces, pues este arraigamiento, esa solidez y lealtad son los factores que garantizan el éxito. Esa transmisión de generación a generación marca la pertenencia física a su barrio, pero también lo recíproco, como el barrio es parte de la personalidad de Antonieta.

En La poétique de l'espace, Gaston Bachelard explica como el lugar donde uno vive se vuelve en una parte inseparable del ser: "En une courte phrase, Victor Hugo associe les images de l'être de la fonction d'habiter. Pour Quasimodo, dit-il (1), la cathédrale avait été successivement 'l'œuf, le nid, la maison, la patrie, l'univers." (92) Lo mismo podría afirmarse respecto a Antonieta, su casa, su barrio y por extensión su ciudad son partes inherentes de lo que ella es y de su proyección vital. Barcelona es el único universo de Antonieta, pues, a pesar de alcanzar el bienestar económico, Antonieta no saldrá nunca de Barcelona, ni para su luna de miel. Es más, el personaje nunca dará muestras de desear conocer otro país, otro lugar, Barcelona es verdaderamente el centro de su vida, y más específicamente su barrio, el cual es una proyección de su identidad. En la Ribera, a pesar de la estrechez de las calles, Antonieta entrevé el sol, y se siente fundamentalmente optimista,

¡Hi havia tan bon veïnat...! ¡Era tan quiet...! ¡Era tan alegre amb los vols dels coloms que, aixecant los ulls enlaire, es vein passar en les migdiades, eixint d'aquell seguit de colomars que s'estenien de cap a cap del carrer...! I si bé era cert que, a l'hivern, sols per l'indret del pisos alts hi 
passava una llepadeta de sol, a l'estiu... ;oh, a l'estiu!: no sols baixava als primers pisos i als llindars de los botigues, sinó que, com una catifa d'or, s'estenia per les rústegues llambordes de l'empedrat.”(55)

Monserdà nos da una visión limitada de Barcelona, la de los pasos de Antonieta, de tal manera que parece que lo que ésta no ve no existe. Su mapa de la ciudad se detiene en la frontera de los ojos de su protagonista. En ese sentido, su clase y su género son los ejes de sus pasos y espacio. Antonieta no sólo está vinculada espacialmente con Barcelona, sino que hay en ella también un vínculo de identidad y una apreciación de los valores catalanes, por lo que es casi imposible separarla de su calle, de su barrio de Barcelona y de Catalunya. Pienso que Monserdà a través de Antonieta emite una reivindicación del nacionalismo con la importancia y el significado que conlleva el hecho de que la primera escritora en Catalunya escribiera en catalán.

Por consiguiente, me parece importante abrir un paréntesis sobre el compromiso de Monserdà y otras escritoras catalanas para el renacer de la lengua catalana, el movimiento literario-cultural conocido como la "Reinaixença." ${ }^{21}$ Es interesante ver aquí que se trata de un grupo de mujeres comprometidas con la misma demanda que preocupa también a los hombres: los problemas del nacionalismo catalán. Monserdà se adhiere así a un feminismo conservador que según sus propias palabras (conferencia citada por Capmany) consiste en "treballar pel millorament de la dona, per defensa del seus drets, per a protestar de les vexacions i de las injustícies de què se la fa objecte; i, en fi, pel perfeccionament de la seva missió en la familia i en la societat" (497). Además se opone al feminismo europeo que le parecía contra "les veritats més fonamentals de la Religió, de la familia i de la societat" (497). Con todo, queda claro que su feminismo, a pesar de 
ser conservador, es nacionalista. Hasta hoy en día, la relación feminismo/nacionalismo tiene una posición difícil, dos términos que se pueden excluir o aceptar mutualmente, sin embargo, en el segunda caso, la igualdad es casi imposible y una jerarquización del nacionalismo casi siempre se impone, de manera que, cuando se trata de escoger, la cuestión se vuelve en un dilema.

Lejos de pensar como Monserdà, Virginia Woolf plantea la cuestión del nacionalismo en una pregunta directa y acertada: "What does 'our country' mean to me, an outsider?" (39) En el caso de Monserdà no es tan claro, ya que para ella "our country," entendido por Catalunya, se ve colonizada por España y por no ser española es catalana. Para ella, su identidad catalana tiene la prioridad y no se lo planteaba como si tuviera que escoger, por un lado se unía a los hombres por luchar contra la soberanía de Madrid y por el otro agitaba una tímida bandera "feminista" en contra de la supeditación de la mujer perpetuada por la soberanía patriarcal. Con todo, la pregunta de Woolf es válida: ¿Cómo las mujeres podían ser nacionalistas si no tenían los mismos derechos? y, al mismo tiempo, ¿Cómo no serlo cuando uno ama y se identifica con su tierra, su lengua, su cultura? Woolf parece encontrar una solución en la negación a una pertenencia nacional y escoge ser huerfana de patria: “'Our country' throughout the greatest part of history has treated me as a slave, it has denied me education or any share of its possession $[\ldots]$ in fact as a woman, I have no country. As a woman I want no country. As a woman, my country is the whole world" (154). Como he mencionado anteriormente, uno de los enfoques principales dentro del feminismo de Monserdà es la contribución y el perfeccionamiento de la "missió" que la mujer debe a su sociedad y a su familia. Esa misión supone transmitir los valores de la cultura catalana, lo que en sí mismo pone a la 
patria como parte de la ecuación y la consciencia de que Barcelona es parte de su identidad contribuye al sentido de nacionalismo de la protagonista.

Monserdà reivindica el derecho a su lengua $\mathrm{y}$, teniendo en cuenta el contexto socio-cultural, nos damos cuenta que la escritura es una herramienta no sólo para defender la condición femenina, sino también para reivindicar la lengua y la cultura catalana, y abrirse paso dentro del entorno al que la mujer no tenía permitido acceder. No es extraño pues que la novela surja con una visión limitada por el género y la clase social, es decir, a través la mirada de Antonieta, una mujer burguesa con la mejor expresión de los rasgos de la sociedad nacional y social a la que pertenece y reflejando el espíritu catalán de emprender con la voluntad y la fuerza necesaria para lograr su meta. El destino de la protagonista traza una analogía con el destino de Barcelona que, por el ambiente histórico y social, no podría darse en ninguna otra ciudad. ¿En qué ciudad del Estado español podemos encontrar en este mismo momento el desarrollo industrial que ofrece Barcelona, dónde había una masa de mujeres trabajadores de fábricas ${ }^{22} \mathrm{y}$, al mismo tiempo, una burguesía emergida del trabajo? Las fábricas en las que había obreras fuera de Catalunya eran las de tabaco de la Coruña, que vemos en La tribuna de Pardo Bazán o en las de Sevilla que encontramos en Carmen de Prosper Mérimée. Por otro lado, solo en Catalunya las mujeres habían alcanzado un espacio público sin detrimento de su reputación y podían trabajar al lado de sus maridos en comercios y negocios, aunque estos fueran de tipo familiar.

De no ser así, Antonieta no hubiera podido desarrollarse, sin salir de su casa, como mujer de negocios y hacer de un pequeño taller una gran fábrica. Esa es la diferencia con el resto de España. Mientras los oligarcas son los que dinásticamente 
controlan todo tipo de industria, en Barcelona se desarrolla una clase media nacida del trabajo que asciende a ser clase alta con un concepto distinto de lo que es ser mujer y esposa. Al mismo tiempo, Barcelona se desarrolla y crece con la industria textil y este crecimiento entre los negocios de Antonieta y los de la ciudad condal están imbricados el uno con el otro formulándose al mismo tiempo que se apoyan el uno en el otro. De hecho, el éxito de la protagonista puede verse como el retrato, la doble interpretación de la sociedad catalana y sobre todo la barcelonesa, es un relato entrelazado donde el trayecto y la evolución de la protagonista refleja el avance de Barcelona. No obstante, este texto va más allá de una simple presentación comparativa entre la evolución de la protagonista y de la ciudad, su entrelazamiento semiótico abarca a la vez el desarrollo de Barcelona y de la mujer, representado aquí por la protagonista. Cabe notar también que es un libro sobre Barcelona y que toma lugar en Barcelona. "Il n'est pas d'histoire, où au moins n'affleurent dans sa narration d'autres histoires [...] (72), escriben Roland Bourneuf, y Real Quellet, en L'univers du roman. En este aspecto, La fabricanta es un relato enmarcado, es decir que si hacemos de Barcelona una historia, entonces es al mismo tiempo el cuadro y el marco Si lo ponemos de otra manera y decimos que el metarelato es una historia en la otra historia, se puede decir que aquí la Fabricanta es el primer relato y no es independiente del relato de la historia de Barcelona y si hacemos de Barcelona el segundo relato, entonces este último es homólogo del primero. No es pensable narrar esta novela amputando la estructura narrativa que es Barcelona, la historia en sí misma desaparecería. Es lo que Gérard Genette, en Nouveau discours du récit, explica de la siguiente manera : "Le metarécit peut être souvent enchâssé dans un cadre sous-entendu, mais clairement impliqué [...] (64). En La fabricanta, el marco explícito, como lo hemos 
visto, es Barcelona, pero también es el marco implícito y la consciencia textual de Barcelona no deja lugar a otro espacio posible. Las veces que se menciona París tenemos implícitamente en el texto a Barcelona. La Ciudad condal se hace omnipresente y la proyección negativa que tenemos de París hace aún más presente Barcelona. Por lo tanto, la novela se recibe completa, no se puede separar lo que es la protagonista de la ciudad por razones de homogeneidad y lo que une todo esto, lo que hace de este cuadro que sea a la vez in and out es la lengua. Escribiendo en catalán cierra la herencia y el testimonio de la identidad catalana de Antonieta (Monserdà), pero sobre todo su pertenencia a Barcelona.

El nacionalismo de la autora da una imagen muy positiva de Barcelona como ciudad democrática, de ahí que el libro se abra sobre el jardín de l'Euterpe, donde se dan conciertos para todas las clases sociales: “[P]er l'estiu de 1860 hi havia instal-lats los jardins de l'Euterpe, a on los coros de Clavé [...] havia realisat la grandiosa obra de posar les magnificències de l'art a l'alcanç del poble" (39). Esa escena, según Teresa Pàmies, es históricamente fiel y da una valorización de la persona y obra de Josep Anselme Clavé, al mismo tiempo que Monserdà capta muy bien el ambiente de la época: "Sens donar-se compte de lo que sentía, però fruint l'encis d'aquella novetat, la gent treballadora invadía els balls [...]" (39). Así pues, desde el principio de la novela, Monserdà describe una "utopía" "una edad de oro" donde el arte reunía a todas las clases sociales en un jardín idílico: “[...] què des d'aquella época ha comptat Barcelona, no se n'ha tornat a veure cap altre" (40). Es preciso recordar que la primera escena tiene lugar en 1860 , si bien la autora escribió la novela en 1904, cuando la asociación ya había 
desaparecido, por lo que la descripción del jardín transmite un tono de nostalgia indudable que se repetirá en el relato.

Desde esta posición, entendemos por qué lo que señala Pike de que: "during the nineteenth century it became a primary image of flux, of dislocation rather than location" (17), no corresponde al estado de mente de Antonieta. De hecho, aquí es todo lo contrario, Antonieta está arraigada a Barcelona, que está en su primera fase de industrialización y en la que, si bien se empieza a vivir esta dislocación que conlleva la emigración del campo a la ciudad de la clase obrera, también hay ese arraigo propio de las clases burguesas. Otro elemento importante que sigue la misma idea es que la ciudad no transforma a Antonieta en el sentido negativo de una transformación, como vemos en muchas de las novelas de finales del siglo XIX que tratan de los principios de la industrialización. Ella crece con la ciudad y lo hace en la misma dirección, au diapasón, en osmosis, pero el tiempo narrativo se detiene en 1875, año que marcará el comienzo de la gran industrialización. Pero por ahora, Antonieta está en su lugar, y lo ejemplifica con el bienestar que siente hablando de su barrio: "[S]i el carrer Mitjà no li pareixia lo més hermós de Barcelona, trobava que, per a viure-hi ella, no n'hi agradava cap altre.”(54). Tampoco existe el concepto que el dinero reemplaza la moralidad, sino todo lo contrario, el dinero es la consecuencia justa y lógica del trabajo y del sacrificio.

Con el avance del relato de los años, Antonieta reemplaza su nostalgia por fuertes críticas y se enfatizan más claramente los puntos negativos de la gran fase de la industrialización:

En quant als progresos materials de la casa, és precís recordar que l'any 1861, i també de més enrera, arrenca la importancia de les 
gran fabriques de la nostra ciutat. Avui no és difícil ésser fabricant, ja que las màquinas $\mathrm{i}$ els enginyers $\mathrm{i}$ els contramestres $\mathrm{i}$ els majordoms són los que fan la feina; mes, en lo temps en què s'establí en Pere-Joan Grau, o seia l'època dels telers a mà, lo primer factor era la intel-ligència i habilitat de l'obrer (202).

Aquí lo deja muy claro, la prosperidad y el éxito de la familia Grau-Corominas es el trabajo y la habilidad de Pere-Joan y la inteligencia de Antonieta, haciéndose hincapié en el merito y la necesidad de ser un buen artesano para tener éxito. No obstante, a pesar de esa nostalgia del trabajo manual, Antonieta compra una fábrica en Sant Martí de Provençals, equipándola de la más moderna maquinaria.

En Barcelona's Vocation of Modernity, Joan Ramon Resina observa que: "In 1854, 6 years after the first Spanish train circulated between Barcelona y Mataró and the year that the Barcelona-Granollers line was inaugurated, the government authorized demolition of Barcelona walls. By launching the era of the boundless city, the train had become the ally of a bourgeoisie that clamored for space and visibility." (21) El punto interesante aquí es que esta visión de apertura deseada por la burguesía es contrario a lo que expresa uno de los obreros de la fábrica: "Donques, si jo manava, lo primer que faria fóra voltar a Barcelona d'unes muralles molt més altes que les que varen treure a l'any cinquanta-quatre i a cada portal hi posaría un regiment de llanceros per a què no hi deixessen entrar ni treballadors de fora ni màquines de l'estranger"(212). De hecho, lo que lo hace aún más pertinente es que en toda la novela la única vez que se menciona, y de pasada, el tren es cuando Corominas lo quiere coger para irse lejos, muy lejos de todos sus problemas. Por consecuencia, el tren y las murallas ${ }^{23}$ representan el final de una 
Barcelona "auténtica", y se perciben con connotación negativa. Barcelona se abre y se extiende con rapidez y ruido, pero también con la sed de dinero que acompañó la fuerte industrialización barcelonesa, lo que Richard Lehan llama: "urban entropy, where nothing provides its energy outside itself" (45).

Como ya he mencionado, la autora coloca a su protagonista en una ciudad que ya no existía cuando escribe la novela. En una Barcelona que todavía estaba en proceso de hacerse la ciudad que después sería. La novela refleja, por lo tanto, un momento en el que lo único cierto era el tipo de ciudad que Barcelona quería ser y que Monserdà añoraría. A través de Antonieta descubrimos la ciudad desde una mirada limitada ya que tal enfoque se realiza desde la diferencia sexual y social. Además sus límites son su barrio a pesar de convertirse en una exitosa "fabricanta". Sin embargo, después de 14 años de trabajo duro, su esposo la obliga retirarse. En consecuencia, la "emancipación" que había alcanzado con su trabajo era algo totalmente ilusorio y éste paso al revés puede verse como la imposibilidad de emancipación para la mujer. Antonieta tiene la virtud de la resignación, y eso se manifiesta en el "feminismo" conservador y católico de la autora. Esa indeterminación feminista de la protagonista también se proyecta en Barcelona. El conocido esquema del sistema patriarcal genera oposiciones binarias y, en este caso, la Antonieta burguesa (masculina por la obvia razón de la explotación) se opone a la Antonieta proletaria (femenina por ser doblemente explotada). Antonieta se queda en el medio, por no tener su lugar propio en una Barcelona cambiante y, cuando las fuerzas de opresión estaban en un momento de tensión de la que tenía que nacer el carácter propio de la ciudad. Ese nuevo paralelismo Antonieta/Barcelona reafirma que el relato de Monserdà solo pueda tener lugar en Barcelona, una ciudad que se estaba haciendo y que 
ya mostraba una serie de rasgos marcados, pero todavía estaba lejos de llegar a ser la ciudad fuertemente proletaria y burguesa que ahora es. De la misma manera, Antonieta, y a través de ella, las mujeres estaban en un proceso de realización en el que veían que su papel iba más allá del doméstico, sin saber cuál podía ser el alcance social que ese papel podía tener, pero sabiendo ya que las identidades sexuales seguirían creando un orden de poder y de acceso desigual a los recursos materiales y simbólicos de nuestras sociedades modernas.

De hecho, esta incertidumbre social se traduce por la ambigüedad que resalta en la interpretación de la novela. Si por un lado las murallas simbolizan la asfixia de la mujer, por otro lado representan la apertura sobre un desarrollo que Monserdà temía por ir en contra de su feminismo. Soñaba con un feminismo que daría a la mujer un papel y un espacio "idílico," propio pero justo, donde la mujer soltera podría ganar su vida decentemente y la casada atender a su familia, transmitiendo los valores morales de la iglesia y de la cultura catalana, y todo eso hubiera podido realizarse antes de la gran fase de la industrialización. En 1904, cuando escribe el libro, la realidad y la transformación social que se está instalando en Barcelona, le hace comprender que la mujer nunca podrá mantener el "equilibrio" que ella deseaba. La ola de la industrialización lo arrasa todo, las obreras se matan a trabajar, sin poder sobrevivir y ocuparse de su hogar y la burguesa se encierra en su casa llena de lujo y materialismo, sin hacer nada para la sociedad. Para Monserdà, la urbanización es casi vivida como una explosión desgarradora y a la frustración se añade la violencia. Así vemos que de Barcelona se hace dos lugares que sirven de correlatos al tiempo: Barcelona de la novela por el tiempo narrado y Barcelona 
de 1904 por el tiempo que cuenta, si el uno y el otro son significativos en sí mismos, el primero lo es específicamente ya que todo el texto se ubica en la primera fase industrial.

Sin embargo, a pesar del "feminismo" conservador de Monserdà quiero creer que el desenlace de la novela es positivo para la condición de la mujer en Catalunya y que Monserdà intuyó y fue visionaria sobre lo que sería la nuevo mujer catalana, o por lo menos lo que podría ser. No cabe duda que Monserdà abrió el paso a las que siguieron y por lo menos sirvió de trampolín con dos de las preocupaciones principales de las escritoras catalanas: la condición de la mujer y la necesidad de recuperar Catalunya a través la lengua y la literatura. De hecho, En La fabricanta es lo que hace, recupera la visión de Barcelona, la recupera y la reinventa, a través los ojos de una mujer. A pesar del conservadurismo de sus creencias, Monserdà entiende la importancia de la catalanidad y de la transmisión de su lengua e identidad. Además, en su novela, Barcelona es emblemática, pero se percibe como una realidad y avanza con la misma energía que la de Antonieta para convertirse en algo más que una capital de provincia de un estado autocrático.

Monserdà, desde su feminismo conservador, dio palabra y vida a una mujer catalana, que sobrepasa cualquier hombre de la novela. Su superioridad es aplastante, y su resignación todavía más. Antonieta es, según Monserdà, la perfecta ciudadana y gracias a ella Barcelona aparece bajo los ojos de otra ciudadana para quien la mujer, la lengua y la tierra catalana son inexorablemente parte de su escritura. Con ella, la mirada de la mujer catalana esbozó una nueva concepción de Barcelona. A tal propósito, Roig lamenta la falta de testimonio sobre la historia femenina de Barcelona: "Dama, señora, menestrala o "chinche": el campo de visión variaba un poco pero, sin ellas saberlo, la 
actitud de mirar las unía. Era una mirada que aún no había encontrado las palabras, las propias, para expresar lo que veía. Y es esto lo que falta a la historia de Barcelona. Y a su literatura."(159), sin embargo, Roig no tiene en cuenta La fabricanta en la que Monserdà empezó conscientemente a buscar y a darle la palabra a la mujer catalana.

No quiero concluir sin observar que La fabricanta se impone como una novela fundacional doble, es decir que engloba a la vez el concepto de Stendhal, por ser el primero en poner el hombre en su biotopo: la sociedad y la Historia y el de Doris Sommer, ${ }^{24}$ quien define la novela fundacional (hispanoamericana del siglo XIX) apoyando su teoría en varios puntos, viendo a las protagonistas como una metáfora de la tierra y demostrando que los matrimonios transgreden el orden social, racial, religioso o económico. Si aplicamos esos conceptos, La fabricanta innova la novela urbana barcelonesa femenina escrita en catalán ya que, al igual que Stendhal, sitúa una mujer catalana en la sociedad industrial en el único contexto social (burguesía) que hace posible su realización en un momento preciso de la historia de Catalunya (la industrialización). Al mismo tiempo, aplicando la teoría de Sommer, Antonieta es percibida como metáfora, sino de Catalunya, por lo menos de Barcelona, pues, perteneciendo a la burguesía, se casa con un obrero y es a partir de esa unión que prospera su negocio, imagen de la prosperidad de Barcelona. Es decir que a partir del trabajo y el talento manual del obrero (Pere-Joan), y de la inteligencia y los fondos económicos de la burguesa (Antonieta) nace el gran éxito mercantil de la pareja y, emblemáticamente, la gran Barcelona industrial de la cual surgirá la Barcelona moderna. Por lo dicho, pienso que se puede considerar $L a$ fabricanta como una novela fundacional y que la construcción de su personaje es ante 
todo una proclamación de un nacionalismo que confirma la idea de Sommer, "every modern individual has a nationality just as he or she 'has' gender." (5) 


\section{NOTAS}

${ }^{1}$ Isabel Segura Soriano en Breve Historia Feminista de la literatura española (en lengua catalana, gallega y vasca) identifica la primera generación de la siguiente manera:

Esta generación de escritoras, ocupa espacios no creados precisamente para ellas. Presentan sus obras en los Juegos Florales, publican, tanto Dolors Monserdà como Caterina Albert, la primera mujer miembro de la Reial Acadèmia de Bones Lletres, espacio de real abolengo masculino. Caterina Albert, travestida públicamente en hombre para escribir como una mujer, era consciente de los márgenes a donde la relegaban. Pero quería traspasar los límites a los que la sociedad biempensante la/las confinaba: el espacio doméstico. (77)

${ }^{2}$ En su libro La rateta encara escombre l'escaleta, Patricia Gabancho explica que: " Or i grana », un setmanal femení de propòsits patriòtics, l'objectiu del qual era formar una "lliga patriótica de dames", per tal de secundar les iniciatives del homes sense tenir-ne cap de propia, com explícitament declaraven! [...] No obstant això, Eugeni d'Ors els va demanar desde "La Veu de Catalunya", que gossessin exercir la crítica envers l'obra masculina. Las paraules de Xènius (Eugenio d'Ors) no podien trovar eco en un grup de dones que pensaven que "el fonament de la patria és la familia" i "el fonament de la familia és la dona": i no en va trovar. (51)

${ }^{3}$ En su tesis Benaiges explica que:

Els factors que poden haver contribuit, segons Carles Carreres (2003), en el possible retard en l'aparició de la ciutat en la literatura catalana són diversos. En el camp dels valors morals i culturals destaca la consideració del concepte terra (entensa com a sòl rústic productiu i sòl urbà, patrimoni i mercaderia, com un valor fonamental, econòmic i moral, dintre de la societat catalana, en general) i certa imposició de la tradició rural -el pairalismecom a defensa de les arrels culturals ancestrals. Des d'un punt de vista econòmic i social, Barcelona apareix lentament a la literatura per la "lenta penetració dels nous valors del capitalisme i en la societat catalana o sedimentació de la memoria". També ho atribueix al fet que els relats en els quals la ciutat de Barcelona és tractada com a un tema principal són obra d'alguns autors i autores que podrien ser considerats relativament marginals dins del panorama general de la literatura catalana com, per exemple, Santiago Rusiñol, Joan Salvat-Papasseit i la mateixa Dolors Monserdà, entre d'altres. (109)

${ }^{4}$ Ciutat Vella: Hablar de Ciutat Vella es hablar de la historia de Barcelona. La historia de una ciudad que vivió amurallada hasta el año 1859 y que hoy es el territorio que queda rodeado por la avenida del Paral·lel, las rondas, la calle de Pelai, el paseo de Lluís Companys y el parque de la Ciutadella. Ciutat Vella está formado por cuatro grandes 
barrios que atesoran muchos otros históricos, con fuerte personalidad y homogeneidad propias. En el sur encontramos la Barceloneta, el barrio más joven, creado a mediados de siglo XVIII con la excusa de realojar a los desplazados de la Ribera para la construcción de la Ciutadella; en poniente, el Raval, que nació a partir de los caminos rurales extramuros de la ciudad, que fue la cuna de la Revolución Industrial del siglo XIX: en el centro, el Gótico, la manifestación urbana más antigua de Barcelona, y en el levante, Sant Pere, Santa Caterina y la Ribera, la extensión medieval de la ciudad. Dolors Monserdà, también nació en el mismo barrio en 1860, en el número 2 de la calle de la Palla.

${ }^{5}$ El Eixample: En 1859 se aprobó el plan del Eixample de Idelfons Cerdá (la característica cuadricula urbana de Barcelona). La gran extensión de terreno que va desde Montjuïc hasta el río Besós y desde los límites de la ciudad medieval hasta las antiguas poblaciones vecinas. La parte central, la derecha del Eixample, fue el barrio de la burguesía que introdujo en sus casas un estilo propio, el Modernismo, el mejor reflejo de aquel momento. A pesar de que en esta zona se concentra un buen número de los edificios significativos, el resto de los que hay también en otros barrios como el Fort Pienc, la Sagrada Família, Sant Antoni y la izquierda del Eixample, fueron influenciados por esta corriente.Todo el Eixample constituye un conjunto arquitectónico modernista único en Europa.

${ }^{6}$ Benaiges explica que Carreras cita a McDonogh (1988) explicando que la vida de Monserdà refleja los cambios de la burguesía de esta época"

Els canvis de domicili de la pròpia Dolors Monserdà, al llarg de la seva vida, mostren la gran mobilitat de la burguesia dins d'un espai urbà que s'amplia extradordinàriament en el darrer terç del s.XIX. Quan es casà en 1865 encara vivia al barri de Sant Cugat del Rec; a mitjans de la década dels 1870 es trasladà ja a l'Eixample, però al sector més proper a la Ciutat Vella, al passeig de Sant Joan; cap als anys 1880 es trasladà novament al passeig de Gràcia, mentre la seva segona residència alternava entre Argentona i el Pirineu; finalment a tombants de segle, la familia es desplaça a Sarrià, mentre ella mantienia un gabinet cap a l'Esquerra de l'Example on escrivi les seves novelas. (200)

${ }^{7}$ Sants: Sants es un barrio de Barcelona situado en la zona sur de la ciudad. Pertenece al distrito de Sants-Montjuïc y limita con los distritos barceloneses del Ensanche al noreste, con el de Les Corts al noroeste y con el municipio de Hospitalet de Llobregat al sur. Sants es un barrio con una marcada identidad fruto de sus orígenes históricos: fue villa independiente de Barcelona hasta 1897, cuando se agregó a la capital.

${ }^{8}$ Sant Martí de Provençals.: El distrito de Sant Martí es el décimo de los diez distritos en que se divide administrativamente la ciudad de Barcelona. Se sitúa en el límite noreste de la ciudad, y limita con el municipio de San Adrián del Besós, y los distritos de Ciutat Vella, Eixample, Horta-Guinardó y Sant Andreu. Comprende la mayor parte del territorio que le da nombre, el antiguo municipio de Sant Martí de Provençals. Fue villa independiente de Barcelona hasta 1897, cuando se agregó a la capital. 
${ }^{9}$ Se entiende por bovarismo el estado de insatisfacción crónica de una persona, producido por el contraste entre sus ilusiones y aspiraciones (a menudo desproporcionadas respecto a sus propias posibilidades) y la realidad, que suele frustrarlas. El termino fue utilizada por primera vez por el filósofo francés Jules Gautier en su estudio Le bovarysme, la psychologie dans l'oeuvre de Flaubert (1892), en el que se refiers a la novela Madame Bovary de Gustave Flaubert, en concreto a la figura de su protagonista, Emma Bovary, que se ha convertido en el prototipo de la insatisfacción conyugal.

${ }^{10}$ En su artículo "El ángel del hogar: "The Cult of Domesticity in Nineteenth Century Spain", Bridger Aldaraca analiza el contexto ideológico que en el siglo XIX, estableció los estereotipos y las características de la mujer como "ángel del hogar".

11 En 1784, las mujeres representaban el 21,1\% del personal de las fábricas, porcentaje que era del $18,1 \%$ en las que se atenían a las ordenanzas, y del $34,4 \%$ en aquellas que no lo hacían. La diferencia con respecto a la fábrica sevillana debe buscarse en la inexistencia de los trabajos de hilanza en el interior de los establecimientos catalanes. La mujer se dedicaba al devanado del algodón, sus salarios oscilaban entre el 50 y el $60 \%$ del jornal de los hombres por el mismo trabajo, cumpliendo jornadas superiores a las diez o doce horas en condiciones muy duras.

${ }^{12}$ L'Euterpe: Jardines que ya no existen y que se situaban a la izquierda del Passeig de Gràcia, entre las calles de València i Mallorca.

${ }^{13}$ Analfabetismo: Según el estudio publicado por Miquel Valls en 2004, Analfabetismo en la Cataluña Central. La comarca de El Bergueda (1860-1930). "En cuanto a la distribución de las tasas de analfabetismo por sexo, observamos que los porcentajes más altos son para las mujeres. Los datos muestran las diferencias de analfabetismo entre sexos, poniendo en relieve el retraso de la mujer en la incorporación a los centros escolares.”(48) En 1860, el porcentaje de analfabetismo para los hombres era de un 60\% y para las mujeres de un $80 \%$, pasó en 1887 a un $48 \%$ para los hombres y un $70 \%$ para las mujeres.

${ }^{14}$ Carme Kar i Alfonsetti 1865-1943 fue periodista, escritora, feminista, musicóloga y publicista. Su feminismo abogaba por dar a las mujeres las herramientas necesarias que las capacitaran tanto para el ejercicio de una profesión como para la igualdad de derechos, quedó ampliamente expuesto en Feminal-suplemento de La Ilustración Catalana- que dirigió desde 1907 hasta 1917 y dónde escribía con el pseudónimo Joana Romeu. También colaboró en e, Diario de Barcelona, La veu de Catalunya, Or i Grana (1906-1907), donde defendió la causa de Solidaritat Catalana, Orfena (1916-17), La Quitxalla (1922-23), La Actualidad, Día Gráfico y Las Provincias de Valencia, a veces con el pseudónimo de Xènia, que hacía alusión al Xenius (Eugenio d'Ors) con quien polemizó en "Joventut".

${ }^{15}$ La muñeca, de Carmela Eulate Sanjurjo fue publicada por primera vez en 1895 en Ponce; la protagonista, Rosario, se casa por interés y es ella la que destruye el 
matrimonio rompiendo con todos los paradigmas sociales estipulados. Se caracteriza por ser una mujer superficial, materialista y por derrochar sin límites el dinero de Julián, su marido; convirtiéndose éste en su víctima. La ruina lo lleva a la desesperación y al suicidio. En el personaje de Rosario también se ven las consecuencias de malos valores educacionales. El carácter insaciable y la voracidad económica de Rosario se mantienen uniformes a lo largo de la novela. Sin embargo, la protagonista no será castigada por ser una niña mimada, todo lo contrario: terminará triunfante. Rosario queda en una mejor posición social que al principio de la historia y sin ningún signo de arrepentimiento por lo sucedido.

${ }^{16}$ En Arraigo conciencia feminista (la mujer en España), Roser Solé explica que:

El feminismo de tipo burgués desarrollado en España se erige en defensor y protector de las mujeres obreras, en una labor más cercana a la beneficencia que a la resolución a largo plazo de los problemas. Y, como dice Geraldine M. Scanion: "Los conservadores, al lograr hacerse con el feminismo lo volvieron inocuo" (56). Catalunya nos dará numerosos ejemplos de este feminismo burgués protector y paternalista que nace en el seno de una clase culta, que ve con preocupación cómo las mujeres obreras por razón de su trabajo en la fábrica van descuidando su tradicional papel de esposa y madre. La influencia de este feminismo se extenderá primordialmente sobre las trabajadoras a domicilio, que por su dispersión será campo abonado para el reformismo social católico. En 1910, se funda en Barcelona el Sindicat de l'Agulla, bajo patrocinio episcopal y presidido por Dolors Monserdà, para denunciar la explotación de las costureras a domicilio Este feminismo va ligado por intereses de clase con el movimiento catalanista impulsado por la burguesía, uno de cuyos frutos sería la publicación de la revista $\mathrm{Or}$ $i$ Grana en 1906. Tanto Dolors Monserdà como Francesca Bonnemaison, fundadora de l'Institut de Cultura i Biblioteca Popular per a la Dona -1909-, no cuestionan la superioridad masculina. Sólo tratan de adecuar la cultura de la mujer y alcanzar unos derechos más acordes con los nuevos tiempos; en ningún caso luchan por la emancipación de la mujer. (11-12)

${ }^{17}$ Xinxe: La mujer obrera en la industria textil catalana durante el primer cuarto de siglo XIX. En Breve Historia Feminista de la literatura española (en lengua catalana, gallega y vasca), Christina Dupláa piensa que: "Sólo las obreras de la industria textil, las «xinxes» (chinches), conocían el espacio público de la la calle y la fábrica. A ellas se las ubica en esta esfera para que dieran la vida y la de sus hijos por el desarrollo de la industrialización catalana" (148).

${ }^{18}$ Víctor Català: Caterina Albert y Paradís (L'Escala 1866-1969). Escritora, conocida con el pseudónimo de Víctor Català, adoptado tras el escándalo que provocó, en los Juegos Florales de Olot de 1898, el hecho de que le fuera premiado el monólogo "La Infanticida" , que los sectores conservadores consideraron impropio de una mujer. Desde entonces, firmó como Víctor Català. Dentro de su obra literaria destaca su novela Solitud (1905) que se encuadra dentro del Modernisme catalán. En esta obra, Víctor Català refleja a través de su personaje principal femenino (Mila) la búsqueda de la propia individualidad y la lucha de esta mujer dentro de su entorno social. Esta obra fue premiada con el premio Fastenrath en 1909 y traducida a varios idiomas. Escribió otra novela, Un film. 3000 
metres y muchas recopilaciones de cuentos: Drames rurals (1902), Caires vius (1907), Contrallums (1930) o Jubileu (1951). También cultivó la poesía y el teatro, aunque nunca vio representado ningún texto dramático propio. El corpus narrativo de sus relatos se presenta coherente y cohesionado a través de diversos ejes temáticos como la locura, la violencia, el tratamiento del entorno, el destino.

${ }^{19}$ La Ciutadella, ocupa los terrenos de la ciudadela construida por Felipe V para dominar la ciudad tras la Guerra de Sucesión Española, en el siglo XVIII. El 11 de septiembre de 1714, tras un asedio de más de 13 meses, Barcelona caía bajo la armada del rey Felipe V, quien para mantener la ciudad bajo un firme control, construyó esta ciudadela o fortaleza, la más grande de Europa por entonces, con forma de estrella, de donde toma su nombre el actual parque y barrio de la Ciutadella. La ciudadela fue parte integrante de un conjunto militar para dominar plenamente la ciudad de Barcelona, en el que, junto a la ciudadela propiamente dicha, se construyó el Castillo de Montjuïc, en la montaña homónima que domina Barcelona desde la altura. La construcción de la ciudadela se encargó al ingeniero militar de origen flamenco Joris Prosper Van Verboom, realizándose entre 1716 y 1718. Para su construcción fue necesario derrocar parte del Barrio de la Ribera, que no sería trasladado a la Barceloneta hasta tres décadas más tarde. Se derribaron 1.200 casas, así como los conventos de San Agustín y Santa Clara, y se desvió el Rec Comtal. En total se desalojó a unas 4.500 personas, que no recibieron indemnización alguna y fueron abandonadas a su suerte. Convertida en un odiado símbolo del gobierno central por parte de la población de Barcelona, la Junta de Vigilancia la mandó derribar en 1841, aunque dos años después, durante la Regencia de María Cristina de Borbón, ésta la restauró dado que todavía no estaba totalmente destruido. Fue el General Prim quien decretó su donación a la ciudad. Por fin, gracias a la Revolución de 1868 , se procedió a la demolición de la ciudadela, comenzando con el derribo de la torre de San Juan, prisión militar situada en la plaza de armas de la ciudadela. De la fortaleza original quedaron sólo la capilla (actual Parroquia Castrense), el palacio del gobernador (actualmente un instituto de educación secundaria, el IES Verdaguer) y el arsenal, actual sede del Parlamento de Cataluña.

${ }^{20}$ Bajtín define el cronotopo en The Dialogic Imagination: Four Essays, como la relación tiempo- espacio, como "the intrinsic connectedness of temporal and spatial relationships that are artistically expressed in literature" (84).

${ }^{21}$ La Reinaixença es un movimiento cultural que reivindica el reconocimiento de la lengua y cultura catalana y reclama más autonomía con respecto al gobierno de Madrid. Se originó en la $1^{\text {a }}$ Republica española, bajo el presidente Pi i Margall, quien estableció un acuerdo que permitiera la existencia de un gobierno autónomo en Cataluña. Esos documentos se llaman las Bases de Manresa y en 1892 fueron establecidos por un dirigente catalán Vicente Almirall apoyado por la burguesía agraria. Este acuerdo reconoce la presencia de un poder regional dentro de un estado federal y marca las diferencias, las atribuciones entre el poder central y el poder regional. Estos acuerdos fueron aprobados con el apoyo de los siguientes partidos: Unión Catalanista, la Lliga y Centre de Cataluña, que eran los movimientos políticos más importantes. A esta recuperación de la lengua y cultura catalana participan además de Monserdà, M. ${ }^{\mathrm{a}}$ Josefa 
Massanés, las mallorquinas Maria Manuela Herreros, Victoria Penya, Margarida Caimari

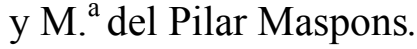

${ }^{22}$ Entre 1780 y principios del siglo XIX, el 20\% de las 120-130 fábricas indianas de Barcelona estaban dirigidas por mujeres. Por otra parte, muchas de ellas, cuando se quedaban viudas, asumían la dirección del negocio de su marido, como en el caso de Rita Gerles, la primera mujer autorizada como fabricante de sedas pintadas. La escritora Dolors Monserdà retrató y homenajeó a estas mujeres empresarias de finales del siglo XIX.

${ }^{23}$ Las murallas: Esta ciudad cerrada por un viejo muro protector fue la misma durante más de 500 años hasta que en el año 1859 desapareció todo rastro de ella. La muralla medieval fue completamente demolida entre los años 1854 y 1856 . La demolición de las murallas fue una de las más añejas reclamaciones de la ciudad, que se sentía atrapada por aquel cinturón de piedra que hacía la capital de Cataluña insalubre e impedía el natural y ordenado crecimiento de Barcelona.

${ }^{24}$ Véase Sommer, Doris. Foundational Fictions: The National Romances of Latin America. Berkeley: University of California Press, 1991. 


\title{
Capítulo III
}

\section{Feliçment, jo sóc una dona}

\author{
Aquesta nit he estimat Barcelona més que \\ mai.[...] Aquesta set d'amor per Barcelona \\ era una cosa completament original: carrers \\ que saps que són teus no pas perquè els
} hagis triats, sinó per tota una Historia qui hi va passar abans de néixer tu; [...] (Roig, Romana adéu 165)

Maria Aurèlia Capmany i Farnés nació en Barcelona el 3 de agosto de 1918 y murió el 2 de octubre de 1991. Era nieta del abogado y escritor Sebastià Farnés (18541934), uno de los fundadores de la Unió Catalanista, e hija de Aureli Capmany (18681954), cestero y folclorista. Los dos, sobre todo el abuelo, tuvieron un gran impacto en su formación literaria. Pero, quien verdaderamente influyó en su personalidad fue su madre, Maria Farnés, una mujer atípica para la época; inconformista y militante de Esquerra Republicana, ${ }^{1}$ Capmany la recuerda así: "A casa meva la influència va ser de tots dos, del pare i de la mare, però el prestigi va ser sempre de la mare. El pare era un home més acomodatici...Tots dos eren molt contestataris, en aquells temps, "anti" totes les convencions que es van imposar en la postguerra, però la mare era també la més iconoclasta i la més valenta[...]" (Montserrat Roig, ofici i plaer de viure i escriure (16)) De hecho, las mujeres de la familia fueron de importancia decisiva durante la niñez de Maria Aurèlia, por ejemplo, la tía Júlia, bibliotecaria de Canet de Mar, la introdujo de muy pequeña al gusto de la lectura. Además de ser de izquierdas su madre y sus dos tías 
fueron seguidoras del feminismo del momento. Julià Lluèsia resume estas influencias de la siguiente manera:

La nena de tirabuixons modernistes, va créixer en un ambient original i pintoresc, començant pel nom d'Aurèlia, d'Aureli, que l'avi Pau Capmany va extreure del protagonista d'una novel-la romàntica, El misterio de las sectas secretas, i que posà al seu únic fill, d'on l'heretà l'escriptora, i continuant per un sistema de valors en què es valora la literatura i el saber per damunt de tot. (96)

No es de extrañar, pues, que creciendo en un ambiento inconformista con una familia liberal, intelectual, catalanista, de izquierdas y en la que el saber era lo más importante, Maria Aurèlia Capmany hiciera estudios superiores perteneciendo a la última generación que pudo asistir al Institut-Escola, un colegio de renovación pedagógica inaugurado por la Generalitat republicana ${ }^{2}$, hecho que la impactó para el resto de su vida. Terminó el bachillerato en junio de 1936, justo antes de la Guerra Civil (1936-1939), y como la misma autora declara, durante la Segunda República: "els estudiants vam viure, en el curt períod d'un batxillerat, amb l'esperit alerta, viu, amb el convenciment que formàvem part d'una empresa que tendía a millorar les relacions de convivència" ( $L a$ dona a Catalunya: consciencia i situació (20). Sin embargo, la victoria del Ejército Nacional lo cambió todo, especialmente para las mujeres, y lo que aconteció fue todo lo contrario a las expectativas de esa juventud crecida bajo la Segunda República. Para seguir sus estudios universitarios, Capmany y toda su generación, tuvieron que revalidar su diploma, ya que el nuevo gobierno, no quiso reconocer la titulación otorgada por la República. En su novela, Lo color més blau, uno de sus personajes es víctima de la 
misma injusticia y declara con desesperación y asco: “[...] Ens tornarem a examinar, doncs?, [...] quan pensó que hem d'explicar que Jaime Primero va lluitar por la unidad de España, em fa mal l'estómac?" (18).

A pesar de esta situación, Capmany llegó a licenciarse en filosofía, aunque, durante los años más duros de la posguerra (los años cuarenta) vivió de su trabajo de grabadora de vidrios. Sus principios literarios fueron difíciles debido a los impedimentos de la censura y al anémico entorno cultural catalán durante la dictadura franquista, pero en 1947, cuando ya ejercía como profesora de filosofía y filología, empezó su creación literaria con Necessitem morir, texto que Anne Charlon califica de novela de la derrota. Con este primer libro quedó finalista del Premio Joanot Martorell ${ }^{3}$ de Novela, pero, por razones de censura, ${ }^{4}$ el texto no se publicaría hasta 1952. En 1948, ganó ese mismo premio con El cel no és transparent, una novela que también tuvo problemas con la censura y que no se publicó hasta 1963 bajo otro título, La pluja als vidres. Su gran prestigio como narradora llega en 1956 con la novela Betúlia; ese mismo año, también sale Tana o la felicitat, y en 1958, Ara. Según Charlon, en 1962, con El gust del pols, empieza la narración de cara al pasado. Este texto es todo lo contrario de su primera novela, pues profundiza en las reflexiones que ya sugería Betúlia, es decir, "Barcelona com expresió paradigmática de Catalunya" (La condició de la dona ,31). En 1967 recibe otro premio, el Sant Jordi con Un lloc entre els morts. Ahora bien, dentro del conjunto de su narrativa Feliçment, jo sóc una dona, (1968), y Quim/Quima (1971), son las más representativas.

En 1959, funda con Ricard Salvat la escuela de arte dramático Adrià Gual, y hace de profesora, actriz, directora, traductora y dramaturga, estrenando tres de sus obras. 
Años más tarde, con el escritor mallorquín Jaume Vidal Alcover, su pareja desde 1969, desarrollará el teatro de cabaret en Catalunya. Después de la muerte del General Franco (1977) y gracias a las reformas políticas del proceso democrático, Capmany se dedica a dar conferencias y a escribir en revistas y periódicos. Con la democracia su figura toma cierta relevancia en la vida política, milita en el PSC (Partit Socialiste de Catalunya) y es nombrada Regidora de los departamentos de Cultura y Ediciones del Ajuntament de Barcelona y miembro de la Diputació de Barcelona, cargos que desempeña desde 1983 hasta 1991. En la segunda mitad de los años ochenta, ya sabiendo que se encontraba enferma, escribió sus memorias. Falleció el 2 de octubre de 1991.

Me parece importante repasar brevemente el contexto socio cultural en el cual escribe Maria Aurèlia Capmany, ya que pertenece a la generación de las escritoras de la posguerra que sufrieron el cambio legislativo que afectó tanto a las mujeres en general como a las autoras específicamente. Una de las particularidades de esta generación es que, de cierta manera, fueron víctima de un engaño, pues crecieron en un entorno de libertad que vieron desaparecer con la derrota republicana. En Catalunya, la represión de la posguerra fue particularmente fuerte debido a la prohibición de la lengua y de la cultura catalanas con el objetivo de aniquilar la identidad catalana y porque el modelo de mujer (esposa-madre) basado en los modelos patriarcales, proporcionando toda la autoridad al hombre, y relegando la mujer a la casa, afectó especialmente a las catalanas las cuales, debido al desarrollo social y económico de la región, eran de todas las mujeres del Estado español, las que más se habían aprovechado del progresismo y del aire de libertad implantado durante la Segunda República. El régimen franquista, apoyándose en las normas de conducta impuestas por el catolicismo, ${ }^{5}$ subordinó a las mujeres a un 
estatus social y económico dependiente de los hombres, ya fueran estos padres, esposos, hermanos o sacerdotes. ${ }^{6}$

Monserrat Palau nos habla de la reflexión que tuvo Maria Aurèlia Capmany frente a todas estas leyes anacrónicas y su sensación de haber sido educada para una realidad que cesó de existir el primero de abril de 1939. Palau escribe: "El franquisme suprimia el món per al qual havia estat educada i tampoc no deixava lloc per a una familia atípica com la seva: intel-lectual, liberal d'esquerra catalanista i sense massa recursos econòmics" (72). Asimismo, la victoria franquista y la represión que siguió durante los años 40, provocaron, según Pepa Edo i Benaiges, un trauma para los escritores y las escritoras catalanes que sería la causa de un periodo de vacío literario. Charlon explica que las condiciones socio culturales impuestas por el franquismo tuvieron un resultado muy negativo para escritoras como Rosa Maria Arquimbau, Aurora Bertrana, Carme Montoriol o Mercè Rodoreda, “[...] exiliadas o reduides al silenci en el seu propi país pararan d'escriure, o bé, esperaran anys abans de tornar a l'activitat literària de forma regular. Tant en unes circumstancies com en les altres, les capacitats creadores van quedar minvades" (La condició de la dona 85).

Según Charlon, entre las dos novelistas en lengua catalana que aparecen a finales de los años 40 (Celia Suinol y M.A. Capmany), únicamente Capmany tendrá una producción regular, Suinol sólo publicará una novela y una selección de cuentos, mientras que Maria Aurèlia Capmany, se distingue tanto por el contenido de lo que escribe como por seguir escribiendo, a pesar de la censura y de la imposibilidad de ser publicada durante años, por decir lo que decía y, sobre todo, por decirlo en catalán. Para el crítico Joan Fuster es "sens dubte, la més representativa d'aquest corrent que, en la 
postguerra, reprèn la jove i voluntariosa tradició de la novel-la catalana." (Literatura catalana 78)

Ahora bien, uno de los rasgos más distintivos de la obra de Capmany es la importancia que en todos sus textos tiene la ciudad de Barcelona. Su visión de la ciudad es el fruto de una reflexión siempre renovada sobre la historia y la sociología de Catalunya, pero sobre todo de la relación existente entre la ciudad y sus habitantes, para ella, la ciudad es la gente y, como lo señala en Diàlegs a Barcelona: $M^{a}$ Aurèlia Capmany /Pasqual Maragall: [...] la ciutat es el poble, la gent, els ciutadants" (46). Ya lo había dicho Shakespeare: "[T]he city is the people" (47). Hecho que queda patente, no solamente en toda la complejidad de sus obras sino también en el reconocimiento del público y de los círculos literarios. Como he sugerido anteriormente, la obra de Capmany es extensa y no sólo por lo que se refiere a la narrativa sino por lo que concierne a sus ensayos y escritos sobre el feminismo.

Como señala Delia Amoròs, es en estos años que muchas mujeres españolas llegaron al feminismo debido en gran parte a las investigaciones sobre las mujeres iniciadas por el gobierno, y en las cuales Capmany, participó aportando materiales para su estudio y publicando dos obras de gran interés social y político: La dona a Catalunya (1966) y El feminisme a Catalunya (1973). Para Amoròs: "Descobrirem en Maria Aurèlia Capmany a una escriptora que veu la literatura i el compromís social com dues manifestacions íntimament relacionades, i que, si per una banda (a las obres de no ficció) pren una posició compromesa pel que fa a la situació de la dona, per altra (a l'obra de ficció) no abandona el tractament del tema" (15). Asimismo, para Capmany la 
condición femenina y la identidad cultural también están íntimamente ligadas sobre todo cuando advierte que la identidad catalana se ve amenazada.

Feminismo y libertad son temas claves para entender la producción literaria de Capmany y también para comprender en toda su complejidad el rol que Barcelona tiene en sus novelas, especialmente el de ciertos momentos de la historia catalana y, de un modo más general, el del proceso seguido por la dictadura española en su evolución durante los años de paz. Ante lo expuesto, resulta evidente que Maria Aurèlia Capmany fue una de las autoras catalanas más polifacéticas de su momento. Como ya he señalado, fue autora de ensayos, dramaturga, crítica literaria, portavoz del feminismo y, especialmente, narradora de la vida de Barcelona y de su gente. Como ella misma decía, quiso siempre demostrar que podía ser más que una autora de novelas "històries de donetes de casa", (La Dona a 57) y que era capaz de escribir sobre Catalunya y su identidad cultural y nacional. La novela que he escogido para este análisis, Feliçment, jo sóc una dona (1968), en la cual aparecen los tres componentes básicos de su narrativa (la mujer, el recuerdo y la historia), nos ofrece también, un buen ejemplo de los intereses de Capmany y del rol predominante que Barcelona alcanza en su creación.

Feliçment, jo soc una dona narra la autobiografía ficticia de Carola. Empieza con su nacimiento en 1899 y termina en el año 1968. Casi toda la novela tiene lugar en Barcelona, salvo un periodo estival en las afueras de la ciudad, y luego en París, donde la protagonista vivirá por 17 años, pero de los que se nos mencionan solamente aquellos aspectos que son necesarios para seguir la tramar argumental. Así pues, Barcelona será el espacio geográfico principal observándose la percepción de la ciudad a lo largo de medio siglo a través de una mirada femenina. En ese sentido, puede decirse que Feliçment, jo 
soc una dona es un retazo de la historia de Barcelona en el que se expresa la ideología de la autora a través de las vicisitudes vividas por la protagonista. En mi análisis me propongo exponer como el feminismo, el nacionalismo y el socialismo de Capmany son la base ideológica de una novela en la que indirectamente se nos narra la historia de una ciudad.

En el prólogo, Capmany nos presenta a Carola Milà, la narradora y protagonista de la novela, una mujer de casi 70 años. De hecho, el prólogo es un resumen muy breve de las principales etapas de la vida de la protagonista en el que se nos ofrecen también los rasgos más característicos de su personalidad y los valores que dictaminaron todas sus acciones ["Els dos amors de Carola Milà eren el diner i la llibertat" (14)] que podría decirse que son también los rasgos que caracterizan también el carácter burgués y libertario de Barcelona. La rebeldía de Carola nos es mostrada desde el principio del relato, cuando su editor le pide que escriba en tercera persona, pero ella, decide que es mejor hacerlo en primera, como en las novelas picarescas: "Per què he d'abandonar jo aquesta primera persona autèntica? Diré més aviat, com la meva estimada Rigolboche "estimo tant la veritat, que quan hagi de fer elogis de mi mateixi sacrificaré la modèstia" (14). El personaje de Rigolboche nos lleva inevitablemente al título que se puede leer de varias maneras, hasta con ironía, pero en el que lo esencial es su fuente y la traducción que Capmany le presta. Rigolboche era una bailarina que hizo la gloria del French Cancan durante el Second Empire ${ }^{7}$ y que en sus memorias declaró que: "Ma 'carrure' et ma position m'ont créé une foule d'antagonistes, parmi mes compagnes surtout. Elles ont répandu sur moi plus de calomnies qu'il n'en faudrait pour faire pendre un homme. Heureusement que je suis une femme" (Feliçment 9). La traducción que escoge Capmany 
le agrega otra connotación, y claro está que lo hace a propósito. En la cita francesa, la idea principal es que Rigolboche tiene suerte de ser una mujer, pues de no haberlo sido, las calumnias hubieran hecho que terminara en la horca. Ahora bien, el adverbio "heureusement," que en catalán equivale a "feliçment," contiene, como en francés, la idea de suerte, pero también la de placer y orgullo, con lo que puede decirse que el título trasmite un mensaje en el que, por un lado, se muestra que el hecho de ser mujer es algo positivo cuestionándose de este modo la idea de que las mujeres se encuentran siempre en una situación social de desventaja con respecto a los hombres y, por otro, nos anticipa que la historia que se nos va a relatar va a ser la de una mujer, pero la de una mujer que sabe triunfar ante las adversidades de la vida haciendo uso precisamente de su supuestamente desventajosa condición femenina.

Siguiendo con el prólogo, Carola Milà explica que su editor, Cosme Tudurí, le pide que escriba sus memorias, pero que las relate como si se tratara de una novela. La imagen que nos da de ella misma es la de una mujer que se acerca a la vejez, feliz y rica, sin embargo, es una felicidad que le costó alcanzar y en la voz narrativa es posible percibir todas las dificultades con las que se enfrentó la protagonista. Hay en su tono, a pesar de una ironía subyacente, acentos de añoranza, remordimientos y tristeza. Frente a la bahía de Pollença en Mallorca, empieza su texto con una interrogación existencialista: "Per on he de començar?" (11), y esta pregunta sirve para enumerar todas las etapas importantes de su vida. Así, de manera muy sucinta, nos prepara para la lectura de sus recuerdos, empezando con su nacimiento y terminando con su vida en París. Ahora bien, como he sugerido anteriormente, Feliçment, jo sóc una dona es un amalgama de historias que relatan la vida de Carola, pero que lo hacen abarcando los años más 
significativos de la historia reciente de Catalunya y es este aspecto el que me parece interesante para mi estudio.

A la manera de la picaresca, el libro está construido como un Bildungsroman porque, por un lado, narra un proceso de ascendencia social y, por otro, un camino de descubrimientos que culmina en una etapa de madurez. Este recorrido a la vez social y humano se encuadra en un espacio barcelonés lleno de implicaciones históricas, por lo que es posible afirmar que Feliçment, jo soc una dona constituye también el Bildungsroman de la "formación" de Barcelona. Ahora bien, la novela de formación en la que Barcelona y no la protagonista es el personaje principal se presenta a modo de palimpsesto, un palimpsesto en el cual, Carola es la imagen más evidente y Barcelona la que se oculta tras ella y que solamente podrá ser percibida por aquellos que estén familiarizados con la historia reciente de la ciudad.

Ante todo, desde el principio, lo que resalta como base constructiva de la novela es la dicotomía entre el mundo burgués y el mundo obrero que, como sabemos, es el aspecto que mejor define a la sociedad barcelonesa. Esta diferencia se establece primero de modo geográfico, es decir, los barrios proletarios, la parte baja y vieja de la ciudad, y la de la burguesía, la zona alta, elegante y moderna. A lo largo, de la novela la diferencia va estableciéndose más y más dentro de varios parámetros, como por ejemplo en el de la lengua, ya sea mediante referencias explícitas, como las malas palabras, la crudeza del vocabulario o mediante la familiaridad. De este modo vemos que el espacio burgués contiene también un peculiar ámbito lingüístico. A principios de siglo, la burguesía hablaba catalán y castellano, mientras que la clase obrera sólo hablaba catalán, ya que el castellano lo aprendían en la escuela solamente aquellos que podían acceder a cierta 
educación y, aunque cierto sector del proletariado lo conocía perfectamente y hacía uso de él, no puede decirse que fuera el lenguaje de la calle como lo es hoy en día.

Carola Milà, hija de madre soltera, nace con el siglo, el 31 de diciembre de 1899, en la calle Jaume Giral en el barrio de Santa Caterina (Ciutat Vella). Su abuelo materno Salvador Milà es portero de la gran fábrica de los Pujades y vive con su segunda mujer, Paula. Su primera esposa se fugó con otro hombre, dejándolo solo con su hija, la que después es la madre de Carola. A los 6 años, Carola y su madre abandonan el piso de la calle Jaume Giral en el que viven y regresan a casa del avi Milà. Carola se entera de que su padre es el hijo del dueño de la fábrica y que, cuando los amos supieron del embarazo, mandaron a su hijo a Londres e hicieron que su abuelo mandara a su hija al carrer Jaume Giral, donde en una habitación de alquiler dio a luz a Carola viviendo allí con la niña hasta que las hicieron regresar a la casa de los Pujades. Un año después, su madre la abandona dejándola sola con su abuelo y con Paula, y, poco después, los Pujades la mandan a un convento/colegio de monjas, en el que todas las muchachas Pujades habían estudiado y en el que se ocupaban también de la educación de niñas pobres protegidas por familias de recursos. El propósito de los Pujades es que Carola reciba una educación para después casarla, es decir, hacer de ella una mujer "honrada" que no siga el camino de su madre. Desafortunadamente, las estrategias ideadas por Carola para mantenerse dentro del ámbito protector del colegio provocan todo lo contrario y Carola es expulsada a los 12 años. Dos años más tarde, los Pujades le encuentran una colocación como dependienta. Un trabajo que hasta entonces se había considerado impropio de una mujer decente, pero que los nuevos tiempos hacían aceptable. Carola conoce entonces a Feliu Codinas, un joven trabajador anarquista del que se enamora y con el que tiene planeado 
irse a vivir, pero el abuelo de Carola, que además de portero de los Pujades es el encargado de salvaguardar sus intereses y los de su clase mediante asesinatos y delaciones de elementos subversivos, lo denuncia a las autoridades, se le imputa un atentado terrorista y es fusilado. La casi simultánea represalia de los anarquistas termina con la vida del abuelo y de su mujer, y Carola, que se encuentra embarazada de Feliu, sufre un aborto en la calle y es recogida por la señora Reinal (a quien miente sobre su identidad y familia). En casa de la señora Reinal -una sufragista que intenta hacer de Carola un portavoz del feminismo- Carola, convertida en Carmina Torres frecuenta la intelectualidad barcelonesa de antes de la Primera Guerra Mundial y vive una existencia protegida y cómoda hasta que se enamora y, al ver su propósito de vivir con el hombre que quiere impedido por la señora Reinal, comprende que no es más que una sirvienta sin paga y decide abandonar a sus protectores. Cambia de nombre una vez más y se emplea como criada, pero al poco tiempo, abandona su trabajo y se pone a ejercer de prostituta. Una ocupación que encuentra menos cansada, menos difícil y mejor pagada. Empezará en la calle, pero pronto se instalará en el burdel de la señora Rosita, donde, por su belleza será reservada a los clientes más ricos. Es en este prostíbulo que Esteve Plans se fijará en ella y, después de una primera noche en un hotel privado, la "compra" a la señora Rosita y le pone un piso. Nuevamente embarazada, terminará casándose con su amante y, una vez recuperado su verdadero nombre, se convierte en la señora Plans. A partir de aquí, vivirá la vida aburrida, pero cómoda de una burguesa hasta que, al estallar la Guerra Civil, su familia se va de Barcelona, pero ella no puede irse con ellos. Su casa es requisada y convertida en un hospital en el que Carola trabaja hasta el final de la guerra. En este periodo, conoce al republicano Benito Garrido, que será el gran amor de su vida, 
pero que nunca regresa del frente. Con la victoria de los nacionales, la familia Plans vuelve a Barcelona, Carola se esconde de ellos y vive pobremente en la parte baja de la ciudad, pero su esposo termina encontrándola y obligándola a regresar con él y su familia. Sin embargo, Carola lleva en sí la derrota que sostuvo Barcelona y sólo es un fantasma de sí misma. Después de la boda de su hija, cansada de llevar una vida sin sentido, intenta suicidarse, pero la salvarán y su vida no será más que un esbozo borroso, hasta que sin ninguna planificación previa, decide huir a París. Con ella se lleva las joyas que ha ido atesorando a lo largo de toda su vida y, una vez en París, adquiere una nueva identidad y abre un restaurante. París es su resurrección, por primera vez, a los cincuenta años, se siente libre y puede hacer lo que le viene en gana. A la muerte de Esteve se entera que éste le ha dejado todo en herencia, pero que su hija intenta impugnarla. A requerimientos de la familia, regresa a Barcelona, arregla la disputa con la herencia, vende su restaurante y se instala en Mallorca, donde se inicia y termina el relato con ella reflexionando sobre las memorias que acaba de escribir y sobre su vida. Ante lo expuesto resulta evidente que nos encontramos ante un relato que tiene mucho de la trayectoria vital propia de una novela picaresca femenina, algo que enfatizan los pequeños prólogos en cursiva que anticipan el contenido de lo que sucede en cada capítulo con la consabida retórica del tipo "De cómo aprendo..." o "Donde se cuenta..".

Como narradora única del relato, todo lo que se nos presenta, tanto los personajes como los acontecimientos, lo percibimos siempre desde el punto de vista de Carola. Sabemos que Carola está recordando y analizando cosas y emociones desde su niñez hasta su madurez, pero siempre hay una bifurcación entre lo que verdaderamente pasó y como ella lo recuerda. Varias veces, Carola expresará sus dudas, sobre todo acerca de las 
fechas, pero se excusa de su falta de rigor histórico en el hecho de que su relato se basa en la memoria y ésta puede ser engañosa. Carola es a la vez testigo y protagonista y su historia es la de la ciudad, pero, al igual que Barcelona, ella ha tenido que olvidar para sobrevivir y, si por un lado sus recuerdos pueden ser confusos, por otro, sus memorias no se formulan como una autobiografía, sino como una novela en la que, para evitarse problemas, las personas que la inspiraron se esconden bajo una serie de nombres inventados. Sin embargo, aquí la protagonista es el centro del relato y su voz es el eco de su historia, pero también del de Barcelona, aunque para relatarse esta(s) historia(s) sea necesario escudarla(s) tras la ficción.

Así pues, la vida de Carola será ritmada por todos los eventos históricos de la primera mitad del siglo XX. Su nacimiento se inicia con el siglo y Carola llega al mundo bajo el estruendo de los cañones de los barcos de la escuadra alemana anclada en el puerto de Barcelona que reciben así el nuevo siglo (11). La imagen de un siglo que se inicia con el estrépito de cañonazos parece predecir la violencia que predominará a lo largo del siglo XX y el que los cañonazos partan precisamente de barcos alemanes en las radas de Barcelona anticipa la vergonzosa y criminal alianza de España y Alemania. Hecho en el que se nos insiste al sugerírsenos la estrecha relación entre la burguesía y el nazismo a través de los diversos personajes que muestran esta relación y los intereses que los Plans mantienen con entidades y organizaciones alemanas.

Junto con la visión histórica y social que la autora da a su relato encontramos también una historia muy personal. De hecho, desde el comienzo, sentimos que estamos ante una novela cuyo argumento está volcado hacia lo doméstico y lo interior, hacia lo íntimo, si bien se intuye cierto deseo por lo lejano y lo exterior. Es este elemento como 
una mirada hacia la lejanía, hacia el mar abierto que encarna el espacio en el que se inicia y termina el relato (la bahía de Pollença) aunque evidentemente no estamos ante el deseo de viaje. Todo lo contrario, a pesar de la constante presencia del mar de Pollença, los primeros capítulos de la narración están, paradójicamente, trenzados por un deseo, casi ineludible, hacia el retorno a la Barcelona natal a una Barcelona que, ante todo, es una Barcelona matriz. La primera descripción que nos da Carola de su barrio está revestida de la imagen de una espiral: "En el meu barri de Santa Caterina el meu coneixement s'estenía, com les muralles d'una ciutat, en cercles concèntrics de creixement" (26). Observamos que esta percepción circular, no da la sensación de encierro ni de ahogo, sino más bien de refugio, un hogar seguro, materno:

Hi havía el primer clos de la cambra, un segon cinturó, que era el pis de la senyora Marina, un tercer molt ample, ja símptoma d'una certa autonomia, que arribava fins al davant de casa; aquest cercle comprenia el pis, l'escala, la botiga de l'ataconador, la lleteria, el fuster, el carreter, i tres escales més tan enfilades i fosques com la meva. El quart cercle arribava fins al carrer Més Alt de San Pere, i va tenir aviat una ampliació amb al mercat. No vaig arribar a aconseguir el cercle de la majoria d'edat que era el carrer de la Princesa i la plaça de Santa Maria. Quan m'hauriat tocat aconseguir-ho, ja era fora del carrer. (26)

Es en el medio y en el núcleo de esta espiral en el que Carola anida, desarrollándose dentro de todas esas circunferencias. Carola se cría, en su calle, paso por paso, círculo por círculo, hasta que es lo suficiente grande para irse. Este barrio son las entrañas de Barcelona, en todos los sentidos, comprende todo el centro histórico de la ciudad, es 
donde, al igual que Carola, "nació" la ciudad, y es donde la ciudad crece. Este barrio de Ciutat Vella es el centro de Barcelona, su ombligo y es esta equivalencia la que nos presenta una Barcelona matriz.

Carola nace en una habitación alquilada por su madre, quien casi siempre está ausente. La voz narrativa, aludiendo al modo en que su madre la abandonó para llevar su vida, dice: "com si ja n'estigués definitivament fora abans de saltar per la finestra" (33). En esa calle del barrio de Santa Catarina, Carola está en cuarentena, lejos de su familia por ser hija del pecado; pero se ve "adoptada" y acogida por el barrio, y los clos son los brazos de una abrazo metafórico que la protegen, la atienden y, que poco a poco, se abren y la sueltan hacia el exterior. Echando la vista atrás, Carola termina el capítulo con estas palabras: "jo devia ser feliç al carrer de Jaume Giral. Al cor del barri de Santa Caterina. On problabement vaig aprendre a viure al carrer i per això mai no m'ha fet por quedar-me sense teulada" (25). Vemos que la calle la cría y le enseña a vivir, por lo que, de ser matriz debido al espacio geográfico que ocupa y a su origen ancestral, el barrio pasa a ser madre por sus enseñanzas y preparaciones a la vida.

Asimismo, la circularidad con la que la voz narrativa nos presenta este espacio se acerca a la imagen del caracol a propósito de la cual Gaston Bachelard se extiende en $L a$ poétique de l'espace. Hablando del caracol Bachelard nos dice: "c'est en roulant sur lui même que le limaçon a fabriqué son "escalier". Ainsi toute la maison de l'escargot serait une cage d'escalier. A chaque contorsion l'animal mou fait une marche de son escalier en colimaçon. Il se contorsionne pour avancer et grandir" (119). Aquí se divulgan dos conceptos, el de la escalera (escalier), quien al igual que el caracol, es donde Carola aprende a conocer la gente y a vivir. En este microcosmos, la escalera, dentro del barrio 
y de la calle es el universo de Carola, donde crece y aprende la vida y, que representa el mundo: “A la porta d'entrada hi havia l'ataconador, [...] Al primer primera, hi vivía un barber amb la seva dona. [...] El segon replà hi havia l'home del bar i moltes dones $[\ldots] "(27)$.

La habitación de Carola está en el tercer piso, así que tiene que subir las escaleras para llegar a ella y bajarlas para salir a la calle, por otro lado, para ir a la azotea le es necesario pasar de su piso y seguir subiendo. En la escalera, con cada peldaño, Carola crece literal y metafóricamente en el tiempo y en el espacio, y va aprendiendo la vida y a conocer a la gente. En este sentido, como para el caracol, toda la casa de Carola es su escalera. Es donde ella se siente bien y por donde se mueve. "L'escala de casa era tan plena que podria datar la meva infancia pels graus de coneixement de cada replà" (17).

El segundo punto que nos interesa lo encontramos en la analogía semántica que encierra la palabra contorsiones, ya que el filósofo francés nos dice que con cada contorsión el caracol adelanta y crece. En el texto de Capmany, tenemos: "M'havien preparat bé en el meu barri de Santa Caterina, sabia las contorsions que calia fer."(35) Aquí es doblemente acertado, tanto en la palabra como en el concepto, el barrio es el caparazón y Carola el molusco y como él crece dentro de su concha, con cada contorsión. Al mismo tiempo, la palabra "contorsión" tiene una connotación muy particular, implica el esfuerzo, la agilidad y, sobre todo, flexibilidad. Es un movimiento que no es natural y que cuesta, un movimiento restringido, interior, dentro del cuerpo, que sin embargo se queda inmóvil en el espacio, no se mueve verdaderamente, por eso cada paso es tan difícil, tan lento y a la vez introspectivo. Así crecen los moluscos, en silencio, despacio y dentro de ellos mismos, solos y en seguida se esconden en una hábil contorsión. Carola 
hace lo mismo, crece sola y la escalera con cada escalón le vale una contorsión, como cuando un vecino vicioso le dice incesablemente, cada vez que la ve por la escalera: "Vina, guapa, que te tocaré el culet!" (29). Es la noción de esfuerzo contenido que, a mi parecer, es importante, pero también la falta de opciones que tienen tanto el molusco como la misma Carola, las contorsiones son, de hecho, su única manera de sobrevivir. A lo largo de su vida veremos que las contorsiones se transforman en estrategias y que, esta herramienta le servirá para alcanzar su meta de libertad y riqueza, único camino para la independencia.

En la calle Jaume Giral, "al cor del barri de Santa Caterina" (17), en "[u]n barri on la gent no cap a les cases i surt a crits per les finestres i balcons" Carola vivirá hasta los 6 años, (17). Como he mencionado anteriormente, este barrio juega un papel fundamental en la estructura de la novela y en la formulación del personaje principal. Es un barrio popular que simboliza humanidad, un microcosmos de la vida barcelonesa en su totalidad. Es donde todo empieza, donde Carola, ya de niña, aprende a defenderse y a conocer a la gente. La falta de cariño de su madre, los gritos y las bofetadas de la señora Marina (cuando Carola no quiere quedarse encerrada en la habitación), marcarán su primera niñez para siempre. Sin embargo, en ningún momento la descripción del barrio es negativa, todo lo contrario. El edificio donde vive le permite descubrir las diferentes clases de gentes que habitan la ciudad, a la vez que la ayuda a conocerse mejor a sí misma. Su barrio, su calle, la prepararán para poder enfrentarse a su futuro, y, cuando a los 6 años se muda a casa de su abuelo, ya está preparada para la dureza de la vida y de las palabras: “[a]l carrer de Jaume Giral m'havien ensenyat molt de pressa tot el vocabulari que podien usar a la cuina i encara més. No m'afectaven las paraulas” (34). 
Por lo que concierne al barrio, es posible establecer un paralelismo entre la protagonista de la novela de Capmany y Antonieta, la protagonista de la novela de Dolors Monserdà, analizada en el capítulo anterior, pues ambos personajes pertenecen a ese barrio origen de Barcelona al que se encuentran profundamente ligados. En Dime que me quieres aunque sea mentira, Montserrat Roig, al hablarnos de la literatura sobre Barcelona, menciona una peculiar mirada femenina, que se quedó silenciada durante siglos: "Era una mirada que aún no había encontrado las palabras, las propias, para expresar lo que veía. Y esto lo que le falta a la historia de Barcelona. Y a su literatura" (159). Como he señalado en el capítulo anterior, esta mirada, desde la perspectiva de la mujer, no fue parte de la literatura urbana catalana hasta que Monserdà abriera el camino con La Fabricanta. Pero para Roig, mucho se ha perdido de la historia de Barcelona, por el silencio impuesto a la mujeres de todas las clases (Dime que 159).

Pasar de la mirada a la escritura es un acto transgresor y una toma de consciencia que Monserdà y Capmany materializan poniendo a Barcelona en el primer plano de sus novelas. Tratan de recuperar Barcelona, aun desde su imaginario, y escriben su ciudad, recobrándola a través de las "pequeñas historias", de una ciudad vista desde la perspectiva y el campo de visión de la mujer. Con esta escritura van de transgresión a transgresión produciendo un texto literario triplemente transgresor, primero por recuperar la historia de Barcelona a través de la memoria femenina, segundo por apropiarse y feminizar la ciudad en un entorno histórico y literario patriarcal y tercero por hacerlo en catalán en el estado Español.

Me parece oportuno mencionar que, a través de la voz narrativa, Capmany dedica todo un capítulo al barrio donde nació Carola y que esto tiene su lógica si consideramos 
que Ciutat vella es también el barrio donde nació Capmany y en el cual vivió hasta los 40 años. No creo por lo tanto arriesgado afirmar que la autora proyecta su sentimiento a través de Carola, quien nace en el corazón de Barcelona, y siendo huérfana de padres se vuelve hija del carrer Jaume Giralt y, con esta filiación hereda la pertenencia individual y colectiva a su barrio. Su apego a la ciudad nace con el contacto directo a la piedra, a las paredes de este barrio auténticamente catalán, que creciendo aprende a quererlo: "Començo a estimar les pedres del carrer i el soroll" (26). Es también una manera, para Capmany, de rendir homenaje a este barrio obrero y a su gente humilde que vive y da vida a la parte más vieja de la ciudad, tantas veces testigo y víctima de los acontecimientos históricos y, que para ella representa la esencia de Barcelona.

Es importante notar que Carola, hablando de sus recuerdos pone en contraposición la memoria proustiana de la madeleine trempée, teoría de la memoria afectiva y, en cierta manera, pasiva, con la memoria activa o voluntaria que Carola provoca para recordar su barrio. De hecho, la memoria recuperada y trabajada que Carola busca y despierta es, a nivel individual, lo que, a nivel colectivo, corresponde a la memoria popular que trata de recordar el pasado histórico de Barcelona erigiéndose contra la política del olvido impuesto por el régimen franquista. Es decir, contra la memoria oficial que durante cuarenta años sólo reconoció los muertos del lado de los nacionales y, que instituyó la conspiración del silencio y de la negación para ocultar las atrocidades cometidas por los vencedores. ${ }^{9}$ Así pues, la búsqueda de su memoria es también la del pueblo y de los vencidos. A tal efecto, Capmany nos ofrece un relato en el que su protagonista indirectamente revindica la recuperación de la memoria histórica de 
Barcelona: "Els records els he de de construir deliberadamente, sobre el paper. I m'he de preguntar: 'Què feia jo l'any 1905?' (30).

Como es habitual en este tipo de relatos, todos los elementos que los constituyen encarnan o simbolizan aspectos de la realidad del momento histórico que se nos narra. Así, los Pujades simbolizan la burguesía industrial catalana, la de las viejas familias burguesas que pensaban que gracias a ellos Barcelona se había transformado en la capital rica y poderosa de principios de siglo XX. Un sentimiento que les daba, de cierta manera, un derecho de propiedad sobre la ciudad. Sin embargo, esta familia tradicional no quiere seguir los pasos de la nueva burguesía barcelonesa que ellos mismos habían propiciado y se niegan a mudarse al Eixample. Como señala la voz narrativa: "Els Pujades habitaven la casa des del 1873. Més d'una vegada havien decidit abandonar-la i anar-se'n a viure a dins de la ciutat o a la casa vella de la Plaça de Santa Ana, o a un dels príncipals dels immobles nous de 1'Eixample. Pero no ho havien fet. [...] seguien arrelats a aquella unitat casa-fabrica on havien nascut i on, potser, es creien eterns" (74). La noción de eternidad es muy interesante, ya que anuda el pasado y el futuro para siempre, futuro que los Pujades de ninguna manera querían diferente del pasado. Nos encontramos pues con una familia emblemática de una vieja burguesía catalana, totalmente recalcitrante a los cambios que introducían los movimientos proletarios encarnados por el personajede Feliu Tobias y por su retórica revolucionaria.

Capmany no nos da una dirección exacta de la fábrica de los Pujades, sólo nos indica que está bastante lejos del barrio Santa Catarina y que se ubica en Sant Andreu. Sabemos que la industrialización que transformó Barcelona a finales del siglo XIX y principios del siglo XX tuvo por consecuencia que se crearan en Sant Andreu 
importantes empresas de textiles y de máquinarias. ${ }^{10}$ Consecuentemente se nos señala que: "L’enorme bloc de can Pujades quedava separat de la ciutat. Havíem de caminar por carrers inexistents, amb arbres esparsos, rocs i tolls d'aigua, $\mathrm{i}$ les inacabables muralles de maons i d'estacades. Fins que no vèiem l'alta andròmina de l'arc de Triomf no podíem dir que érem a Barcelona." (20) Esta larga distancia espacial entre Santa Caterina y Sant Andreu es figurativamente la brecha entre el barrio popular lleno de vida, donde los niños son libres y exploran su barrio, y el encierro de la casa burguesa de los Pujades en Sant Andreu:

Vull justificar aquests records i la presència d'unes imatges reblades a aquell temps, dient que la intensitat amb que es dibuixen deriva de l'oposició d'aquells dos escenaris, a una banda, al bell mig de la ciutat, el moviment incessant, el tub de crits del celobert, l'escala fosca amb els diversos replans i la gent canviant a cada replà, i el carrer ple de criatures que campaven pels seus furs:els petits, fins als limits del carrer de Sant Pere més Alt, al nord, el de Més Baix al sud, i els altres que ja s'aventuraven pels estrets carrerons: Flassaders, Carders, fins a l'amplada del carrer de la Princessa, i encara, si tan atrevits eren, fins a la font de la plaça de Santa Maria del Mar; i a l'altra, a tocar Sant Andreu, les altes parets de can Pujades, amb la reixa que només s'obria per deixar pasar els carros, que deixaven unes roderes profundes en el camí sense empedrar. (23)

Una imagen que, como es posible observar, acentúa la sensación de encierro de la casafábrica de los Pujades, donde el abuelo Milà como portero, más bien como perro 
guardián, vigila y protege a la familia (21). De hecho, el hincapié que se hace sobre el encierro de la casa de los Pujades, “amb la reixa que només s'obria per deixar pasar els carrors, "conlleva varios significados. Por un lado representa la mente cerrada de la burguesía y su malestar por compartir el espacio con el proletariado y, por otro, ilustra la falta de libertad y las represalias que el avi Milà, inflige a los obreros y a Carola. Como la protagonista declara es: “[1]'única autoridad que hi havia enfront meu era l'avi Milà, i jo no me l'estimava" (22). Es el "ojo del padre," literalmente para Carola y para los trabajadores constituye la representación de la autoridad siempre vigilante o, con un desplazamiento semántico, lo que Michel Laronde al hablar del sentimiento que los emigrantes tienen en los territorios de acogida denomina "efecto panóptico." $(67)^{11} \mathrm{La}$ sensación de ser víctimas de un derecho a la vigilancia que convierte la mirada en un poder de control, siempre presente y en espera. Una sensación temida y, por supuesto, no querida.

La historia de Carola nos es relatada de manera lineal, sin embargo, no se lee verdaderamente de manera linear ya que la narradora mezcla muchas veces en un mismo capítulo diferentes periodos de su vida. Al mismo tiempo, las huellas históricas que funcionan a la manera de un palimpsesto se superponen a la vida de Carola y la narración se presenta como un ir y venir constante entre todas las etapas de su vida construidas sobre capas de la historia de Barcelona. Un recorrido a veces complicado, como su vida, donde todos los personajes y acciones se interrumpen los unos a los otros. Es un relato patchwork que, antes de llegar a una visión global de la obra, nos obliga a leerlo por completo y atentamente. Así en el capítulo dos, se mezclan la vida de Carola en Ciutat Vella y su vida en la casa de los Pujades. 
A los doce años, los Pujades piensan estar dándole una dote que le abrirá las puertas a un buen matrimonio al conseguir que sea admitida en el Col-legi del Bon Consell. Un colegio muy elegante, en el que habían estudiado todas las jóvenes Pujades (como la mayoría de las hijas de la burguesía barcelonesa) y en el que, como he señalado anteriormente, se aceptaban a muchachas pobres apadrinadas por familias ricas, si bien no por ello las monjas dejaban de explotarlas con todos los quehaceres del convento haciendo que las niñas pobres se sentieran encarceladas.

En el relato se hace mención a dos conventos que fueron transformados en cárceles para mujeres. El anteriormente mencionado y a propósito del cual la voz narrativa nos dice que: "El convent del Bon Consell ja no existeix. Va ser, en acabar-se la nostra guerra, presó de dones" (37). Se trata de L'Asil del Bon Consell, ${ }^{12}$ en el barrio de Les Corts .El otro convento es la de la iglesia Sant Pere de les Puelles, ${ }^{13}$ donde Carola es bautizada por primera vez (22). Esta iglesia convento se encontraba en el barrio en el que nace la protagonista y fue quemada cuando Carola todavía era una niña, durante la semana trágica de $1909 .{ }^{14}$ Los sucesos históricos que transformaron estos lugares, y que son de importancia crucial en la historia de Barcelona, son las capas inferiores del palimpsesto y abren la espiral histórica del relato. Como es sabido, muchos conventos fueron destruidos y las monjas fueron víctimas de la violencia anticlerical, pero Capmany no menciona estos aspectos. Este silencio se repetirá varias veces en la novela, por lo que nos encontramos constantemente con referencias históricas implícitas, lo que hace que el texto sea comparable a un iceberg cuya parte visible dependerá del conocimiento que los lectores tengan de la historia de Barcelona. En otras palabras, a lo largo de todo el relato, hay un trasfondo histórico subyacente que se queda en los blancos 
del texto, por lo que lo no dicho de la historia de Barcelona reclama la necesidad interactiva entre el texto y el lector.

Asimismo, el convento/escuela actúa también como ejemplo de la sociedad represora en la que la enseñanza era un aspecto más de esta represión. Como señala la voz narrativa en la escuela: "[v]aig aprendre a parlar castellà y francés" (43). Es decir que la autoridad ejercida por el mundo clerical hace del convento el lugar donde se aprende la lengua impuesta por el gobierno. Obsérvese que, al decir que en el convento aprendió a "hablar" el castellano y el francés, la autora pone los dos idiomas al mismo nivel de lenguas extranjeras, sugiriéndonos de este modo que el catalán es la lengua única y legítima de Catalunya por ser la del pueblo, de su memoria y de su historia.

Al salir del convento se nos menciona otro aspecto que supuso un cambio en la historia del Barcelona: el transporte público. La aparición del tramvia de Les Corts no es tampoco una alusión fortuita, sino otro testimonio de una de las etapas de la industrialización de Barcelona. Efectivamente, si Capmany habla del tranvía es porque la primera línea que circuló en Barcelona fue la de Sant Andreu del Palomar ${ }^{15}$ y porque fue en Barcelona donde circuló el primer tranvía eléctrico del Estado español. En la memoria popular éste fue un acontecimiento memorable ya que la gente tenía medio de esta nueva tecnología y fue necesario mucho tiempo para que los barceloneses se acostumbraran y creyeran que era un medio de transporte seguro. El escenario urbano no es pues, de ninguna manera, anecdótico, sino que, como es posible observar, es un componente esencial para el entendimiento de la novela. Consecuentemente, a lo largo del relato, Capmany entrecruza el referente histórico con la historia de los personajes. 
Asimismo, el texto y su escritura, se apoyan constantemente sobre elementos de la realidad que son unas veces puestos en evidencia o, como ya he mencionado, ocultados.

Dos años después de ser expulsada del colegio, cuando tiene catorce años, la señora Pujades le encuentra a Carola un trabajo como dependienta en una tienda de la calle Fernando (en castellano en el texto). Urbanísticamente, esta tienda, es una muestra de los cambios que se hicieron en el carrer Ferran a finales del siglo XIX y principio del XX. Allí se podían encontrar las tiendas más elegantes de la ciudad, por lo que, a pesar de encontrarse en Ciutat Vella, se convirtió en un paseo habitual para muchos barceloneses; pero lo que verdaderamente interesa de esta localización es que para la protagonista: "[a]quell anar i venir del carrer de Fernando a can Pujades era la seva primera experiència de llibertat" (86).

Es la primera vez en el texto que Carola se siente libre y, como vemos, esta libertad se asocia con las calles de Barcelona. Éste es también el episodio en que el personaje descubre su cuerpo, algo que se nos plantea ligado a una sensación de libertad. A tal propósito, es posible afirmar que la toma de conciencia del cuerpo que encontramos en el relato se acerca al fenómeno que Hélène Cixous expone en La jeune née. Es decir que la toma de consciencia del cuerpo pasa por la necesidad de recobrar mediante la palabra este mismo cuerpo que siglos de androcentrismo le han robado: "Les femmes ont vécu en rêves, en corps, mais tus, en silence" (34). Según Hélène Cixous, la mujer tiene primero que descubrir su cuerpo y de la consciencia del cuerpo pasar a la necesidad de recuperarlo, de des-objetivizarlo, de gozarlo pues, solamente a partir de su cuerpo podrá escribir y hablar su propia lengua, encontrar una voz perdida y prohibida por siglos dentro de una sociedad falocentrista. Así, cuando Carola toma el primer baño de su vida 
y se ve desnuda en el espejo por primera vez, descubre y toma consciencia de su cuerpo: "Coneixia la mirada de la gent entendrida i meravellada, pero no coneixia l'existència del meu propi cos" (65). A partir de este momento, se establece la equivalencia entre decir la ciudad y decir el cuerpo. En otras palabras, se establece de este modo un paralelismo entre el descubrimiento de su cuerpo, su sexualidad (la pérdida de su virginidad por amor) con el descubrimiento de Barcelona que, al igual que su cuerpo, descubre palmo a palmo, disfruta y ama. Así pues, partiendo del barrio de nacimiento, el mapa de su Barcelona se extiende y a medida que va conociendo, que va tomando posesión de Barcelona, aumenta su amor por la ciudad. Barcelona crece con ella y aquí, como veremos, lo que no era no era visible, su cuerpo, su ciudad, se hace visible y explorable por el paseo y por el acto sexual, casi un ritual de pasaje de la niñez a la adultez. Por lo tanto, del descubrimiento del cuerpo pasamos a la construcción de su ser, algo que está directamente ligada al descubrimiento de nuevos espacios y a la construcción de su mapa personal de Barcelona. Al mismo tiempo, la apropiación de la ciudad y el reconocimiento de su cuerpo constituyen un acto subversivo. En este sentido se duplica la ecuación de mujer cuerpo a mujer ciudad y Carola empieza a dibujarse más y más como un símbolo de Barcelona. La toma de consciencia del uno como del otro es casi simultánea y es con toda la fuerza de la juventud que, a pesar de la distancia, Carola camina alegremente de Sant Andreu a casa Campins. Este mismo carrer Ferran, que une la Plaça Sant Jaume y la Rambla unirá también Carola y Feliu, su primer amor, un joven obrero vidriero de 16 años, anarquista y sindicalista.

Como he adelantado anteriormente, si Pujades representa la burguesía catalana, Feliu Tobias representa, la clase obrera, con fuerte conciencia política de orientación 
anarcosindicalista. Feliu empezó a trabajar a los nueve años y vive con su abuelo en las barracas de Pekín, ${ }^{16}$ Poble Nou, (barrio reconocido como un feudo del anarquismo en el mapa político de Barcelona). Su abuelo, como muchos en este barrio, venía de las afuera de Barcelona (Berga) ${ }^{17}$ y era de familia de teixidors. Un oficio que las nuevas tecnologías había hecho desaparecer, como ya empezamos a verlo en La fabricanta. Nuevamente nos encontramos en el relato con la consabida división de las clases sociales barcelonesas, con dos extremos los Pujades y los Tobias. Feliu simboliza la clase obrera anarquista y la futura generación que logrará la llegada de la Segunda República. Una clase cuya ideología se debía a una formación totalmente autodidacta e izquierdista. A Feliu le enseñó a leer su abuelo que: "[t]enia tres llibres de proprietat que guardava curosament folrats, un de molt gros, amb gravats, que, per llegir-lo, calia desembarassar la taula: El masón errante o los misterios de la Ciudadela, Què es la propietat, en la edició de 1870, de B.J. Proudhon, i per fi un llibre molt gruixut, amb lletra molt petita, [...] Assaig d'una moral sense obligació ni sanció."(88). A su vez, Feliu actuará como mentor de Carola.

La relación de Feliu y Carola actúa a modo de metáfora de la relación que el anarquismo tuvo con el pueblo barcelonés. De ahí que su romance se vea presidido por el didactismo y que la lectura ${ }^{18}$ sea una parte importante de la relación. Feliu siempre tiene un periódico o un libro que comparte con Carola con el fin de hacer de ella un individuo librepensador, consciente y crítico: "Feliu li portava llibres para llegir, [...] que explicaban coses de França i d'Itàlia, i el món es feia ample" (88). Conforme a la misma idea, Feliu también le habla del pintor Gustave Courbet, ${ }^{19}$ quien, en nombre de la libertad de pensamiento, no aceptó la Legión de Honor francesa. La alusión a este pintor 
no es gratuita, de hecho, el texto, una vez más sigue una técnica de superposición propio de las muñecas rusas, albergando las referencias históricas las unas dentro de las otras, puesto que detrás de Courbet se encuentra la figura de Prudhon . Así pues, la presencia de Prudhon, el anarquista "por excelencia," se detecta tanto en las referencias a los libros, en la intertextualidad o en el discurso de Feliu. No cabe duda pues que el anarquismo se encuentra muy presente en este capítulo por haberlo sido también históricamente en Barcelona, conocida en este periodo de atentados anarquistas como la ciudad de las bombas. Capmany también describe las reuniones clandestinas por las noches, por ejemplo, la del Centre Obrer del carrer de la Creu en Badalona, el cual existió en realidad, al igual que muchas otras que agrupaban sociedades obreras de carácter libertario. Asimismo, el personaje de Feliu introduce el violento enfrentamiento con la burguesía cuya consecuencia serían los atentados anarquistas y el pistolerismo empresarial. $^{20}$

Ahora bien, si Feliu encarna la idea anarquista según la cual la educación era una de las herramientas fundamentales para asegurarse la creación de la futura sociedad anarquista, los recorridos de Carola por las calles de Barcelona simbolizan un método educativo contrario al establecido que podríamos denominar de "anárquico," un método que permite la lectura, la desobediencia y la rebeldía. Carola se hace de esta manera cómplice y simpatizante anarquista.

En uno de sus estudios, sobre Ferragus de Honoré Balzac, (Le lieu et le sens: l'espace parisien dans Ferragus de Balzac.1980), Henri Mitterand, establece varios niveles de análisis que podrían ser adaptados a la lectura de nuestra novela. El primer nivel es que los topónimos reales, descripciones de lugares que existen verdaderamente, 
es decir, presencia de lo real en la ficción, difusa en el discurso una ilusión realista. Es exactamente lo que ocurre con la descripción de los barrios habitados por las diferentes clases sociales de Barcelona. En el segundo nivel, demuestra como las calles de París, (en nuestro caso Barcelona) debido a sus determinantes sociales, sirven a la acción en la novela; es decir que las calles son referentes sociales, por lo que en una calle determinada no puede desarrollarse la misma acción que en otra. Y lo que, para mi análisis, me parece lo más importante, es que es el lector quien debe de establecer el vínculo entre las calles mencionadas en la fícción y sus características reales, sobre todo históricas. Capmany trata que el lector lea no solamente entre líneas, sino que efectúe una lectura palimpséstica de la novela.

A tal efecto, a lo largo del texto, Capmany omite muchas veces la fecha exacta de los sucesos, dándonos el mes, pero ocultando el año, por lo que tenemos que calcular a partir de la edad de Carola, el año de los acontecimientos. De este modo, el atentado anarquista que planean Feliu y sus amigos se sitúa seguramente en el año 1913 siendo anterior a la creación de la Mancomunidad de Cataluña, ${ }^{21}$ y aunque nos hace pensar al atentado que el 5 de septiembre de 1905 costó la vida a dos populares floristas de las Ramblas y no a la bomba del Liceo, suceso acaecido el 7 de noviembre de 1893, y que Permanyer denomina: "La bomba que desgarró la Barcelona de fin de siglo" (1), lo cierto es que no puede tratarse de ninguno de los dos y que la intención es vincular vagamente ese momento de la vida de la protagonista con un momento de la historia.

Resulta pues evidente que Capmany pone al mismo nivel los hechos de la vida cotidiana y de la historia oficial creando una fusión entre los dos niveles de lectura, es decir la historia de Barcelona y la historia de los personajes. De ahí entendemos que la 
primera historia de amor de Carola esté marcada por la violencia y por el protagonismo de la ciudad. No puede ser de otra manera, la realidad social de la Barcelona de principios de siglo pasaba por un periodo de fuerte violencia y los acontecimientos que iban a cambiar a la sociedad catalana se vivían diariamente en las calles. Por lo tanto, la relación entre Carola y Feliu se desarrolla enteramente en las calles: "Carola i Feliu, ara, es trobavan cada dia en un lloc diferent. Ell li havia assegurat que era millor no fer mai el mateix camí. I caminaven, a vegadas fent marrada, trencant cantonades a l'atzar, descrivint una xarxa de camins nous ara pels carrerons de Santa Caterina, ara per la Rambla, fins a trovar les voreres de l'Eixample" (93). Aquí se describe una Barcelona cómplice, grande, cuyas calles esconde y protege a los amantes, una Barcelona que Carola ella va descubriendo y construyendo en sintonía con su amor.

No obstante, cuando Carola se entera del arresto de Feliu, corre primero a su casa en la calle Còdols y luego a la de su abuelo, pero a su llegada, los amigos de Feliu ya habían matado al viejo Milà y a Paula, y aquí, Carola arranca un recorrido al revés, "Quan va obrir-se pas de recules per no veure el cos de l'avi, i es va trobar a fora del cercle de gent, va arrencar a córrer" (98). Su huida la llevará figurativa y literalmente a una Barcelona que no conoce. Camina hasta el cansancio y se pierde. En la calle Balmes cruza las vías del tren y llega a la Rondes que sigue rumbo al mar. El aire del mar, aire de libertad, la ayuda a respirar, pero cuando ya es oscuro se va hacia el carrer Ample y se deja llevar por la ciudad, carrer de Banys Nous, bajada de Santa Eulàlia hasta la plaza de Sant Felip Neri donde se duerme en un banco. En la elección de esta plaza vemos nuevamente como la historia de Barcelona se entremezcla con la de Carola. 
La plaza Sant Felip Neri, situada en el Barrio Gótico, está cargada en la novela de simbolismo, puesto que es en esta plaza donde Capmany hará que Carola sufra un aborto y el hijo de Feliu muera junto con los ideales de libertad e igualdad que Feliu había inculcado en Carola. Esta plaza está presidida por una iglesia, una de las pocas de estilo barroco de Barcelona, que el 30 de enero de 1938, fue bombardeada por la aviación italiana, aliada del ejército franquista el 30 enero de 1938. En el bombardeo murieron 42 personas, entre ellos 20 niños. Asimismo, la fachada (la única parte del edificio original que quedó tras el bombardeo) fue donde las tropas franquistas fusilaron a muchos republicanos cuando tomaron Barcelona. Por lo que la muerte de Feliu y el aborto de Carola en esta plaza remiten al lector a esos hechos luctuosos de una posterior derrota del pueblo barcelonés.

En la plaza Sant Felip Neri, la señora Reinal encuentra a Carola, se la lleva a su casa, la "adopta" y le ofrece una vida burguesa. Es un cambio total para Carola, quien para no ser expulsada del cómodo refugio que le ofrece la señora Reinal, se inventa una nueva identidad. Dice llamarse Carmina Torres, ser huérfana, no haber sido bautizada nunca, con un abuelo muerto en las inundaciones del barrio de Pekín. Escogiendo este barrio emblemático de las clases más desprovistas de la ciudad, donde la gente vivía en barrcas insalubres. Campany menciona esta parte de Poble Nou, siguiendo su elaboración de la dicotomía social entre la clase pobre, de los obreros que la industrialización aglutinaba en condiciones inhumanas y que hicieron la riqueza de la burguesía industrial de Barcelona.

Una de las primeras cosas que hace la señora Reinal, es bautizar de nuevo a Carola/Carmina, y el 12 de octubre de 1913 Carola se bautiza por segunda vez. Este 
sacramento se celebrará en la capilla de las monjas Clarisses: "També aquesta fe de baptisme va ser cremada, precisament el dies de juliol de 1936 i de l'incendi de la petita església de les Clarisses en sorgia el majestuós saló del Tinell” (136). Si intentamos percibir dentro del texto las oscilaciones de los referentes espaciales y temporales, observamos que esta cita nos reenvía a las dos otras iglesias que fueron quemadas durante los tiempos revolucionarios en Catalunya. Si lo recordamos bien, vemos que la primera iglesia donde fue bautizada Carola fue quemada durante la semana trágica de 1909 y el convento del Bon-Consell fue quemado en 1936 al igual que la de les Clarisses. Es una repetición de la historia, de los tiempos de rebelión, que subraya el anticlericalismo de las sublevaciones catalanas.

El segundo bautizo de Carola aporta también un elemento de lo que podría denominarse "inter historicidad" y también cierta ironía. Carola se bautiza el 12 de octubre, lo que nos recuerda automáticamente el día del descubrimiento de las Américas por Cristóbal Colón y es en este "mismo" saló del Tinell donde, según la tradición tuvo lugar la entrevista entre Colón y los Reyes Católicos, al regreso de su primer viaje de América en 1493. Claro está, que tal elección debe de responder a un propósito de la autora de remitir al lector a este acontecimiento que el gobierno español ha convertido en una celebración nacional. Ahora bien, la primera celebración en el Estado español del Día de la raza data de 1918, (durante el reinado de Alfonso XIII), luego pasó a ser Día de la Hispanidad (en 1981), y terminó siendo Fiesta nacional de España desde 1987. Así que Capmany, al situar en el Saló del Tinell el ritual que formaliza la reinvención de Carola, alude a emblemas del Estado español con los que Catalunya nunca se identificó 
(12 de octubre, Saló del Tinell) y que son tan falsos como la Carmina en que se convierte Carola.

Después del bautizo, Carola vive seis años con la sufragista señora Reinal manteniendo con ella una relación que recuerda la de las protagonistas de la novela de Henry James The Bostonians, pero cuando Carola comprende que el control que la Reinal ejerce sobre ella la pone en una situación semejante a la esclavitud, pues en realidad es una criada sin paga que, a pesar de ser tratada como una señora, carece de todo tipo de libertad, huye de la casa de los Reinal y se pone a trabajar de criada. Ahora bien, ante la dureza del trabajo, la mala paga y los abusos de los dueños, decide hacerse prostituta.

Carola trabaja primero en la calle y luego en un burdel de tal modo que la prostitución en el relato cumple un rol importante en varios niveles. Primero, porque desde el punto de vista moral y social que nos la presenta Capmany nos es planteada como una profesión de servicio más y segundo porque la prostitución nos introduce a otro aspecto de las sociedades urbanas. Si tenemos en cuenta el primer aspecto, piénsese que la situación de la prostituta ha sido recuperado por el feminismo como símbolo de la transacción mujer/mercancía, lo que la hace entrar en una economía urbana y política. ${ }^{22}$ Ahora bien, visto en el contexto de la prostitución, y del punto de vista urbanístico, el uso del cuerpo de la mujer es principalmente público, y en este caso, el cuerpo en sí, es como una calle o un barrio un "espacio público". Esta comparación hace que el cuerpo femenino se vuelva, en un pasaje donde el cliente circula, un lugar donde converge lo humano, lo urbano y lo económico. Utilizando una metáfora un poco más gráfica se puede decir que, entrando en el cuerpo de la prostituta, se entra en un cuerpo público. El cliente se aloja donde tantos otros han residido. Este cuerpo es, al grado más alto, un 
pasaje en el sentido de callejón. Aquí es de notar que una vez más Carola, se confunde con Barcelona, con sus calles, su historia y su papel se mezclan al tejido urbano e histórico de la ciudad, transformándola en una imagen metafórica de Barcelona. Asimismo, en lo que respecta a la situación de la prostitución en el contexto urbano, se podría también decir que la prostitución es la condición sine qua non para el buen funcionamiento de una ciudad. De hecho, permite calificar un barrio o una calle, trayendo así un parecer de urbanidad al espacio de la ciudad. De este modo, la prostitución tiene una doble función en el relato, pero las dos entran en el cuadro urbanístico, o embellecen la ciudad por los que la ven como pura expresión del eros, o todo lo contrario por hacer del espacio urbano un lugar degradado. Ahora bien, en ambos casos la prostituta es parte inseparable del espacio urbano, como lo son los prostíbulos que Carola, con su poco convencional sentido moral, ve como conventos, pues en ellos se vive rodeada de mujeres aburridas bajo la supervisión de una "madre superiora."

Mientras Carola es prostituta de burdel conoce a Esteve Plans, quien a pesar de verla en el burdel se acerca a ella cuando está desayunando en La Maison Dorée. ${ }^{23} \mathrm{La}$ Maison Dorée es un café/restaurant famoso y elegante de la época, o por lo menos, es la referencia que el lector, a primera vista/lectura cree correcta. Sin embargo, contrariamente a las apariencias, Carola no está tomando su café en el muy prestigioso restaurante La Masion Dorée, sino en él que existió después de su desaparición bajo este mismo nombre. El primero cerró en 1918, y se abrió otro con el mismo nombre en la misma plaza, pero sin la misma categoría. La confusión en sí parece anodina. Capmany ni inventa, ni miente, pero tampoco nos da una fecha exacta, correspondiéndole al lector datar el sistema referencial de las experiencias de la vida de Carola para poder deducirlo. 
$\mathrm{Si}$ el lector realiza este acto, comprende que la elección de la autora conlleva un significado, Carola (como La Maison Dorée de la novela) tampoco es lo que parece, bajo su belleza y su aire de princesa no es "de categoría." Al igual que un lector inadvertido, Esteve no pone atención en los detalles y se equivoca escogiéndola a ella sólo por su belleza. En este sentido, la metáfora Carola/Barcelona se repite, Carola como Barcelona tienen fachadas y nombres que engañan, por lo que Esteve se perderá en ella más de una vez, en todos los sentidos de la palabra.

Es al hablar del encuentro con Esteve que Carola subraya el placer que sentía al estar sola y libre: “una de las cosas que m’estimava més del món era esmorzar sola, en un café qualsevol; veient pasar la gent o tornar caminant, sense presses, cap a casa" (178). Carola disfruta en la calle, puesto que para ella, es un referente de libertad. Libertad que pierde cuando Esteve la instala en un edificio del "carrer Aribau, just allí on el tren tombava cap a Sarrià" (180), calle que inmediatamente nos recuerda a Andrea, la joven protagonista de $\mathrm{Nada}^{24}$ de Carmen Laforet, confinada en el horrible y deteriorado apartamento de esta misma calle. Andrea no encuentra su lugar en Barcelona, solo la "nada" y sufre de soledad, síndrome típico de las grandes ciudades. Al contrario que en el personaje de Carmen Laforet, el personaje de Capmany goza de estos momentos de soledad y nunca se siente desorientada en el espacio urbano, el cual se apropia sin miedos.

Ahora bien, los solitarios recorridos de Carola no son nunca el paseo de flâneuse, no solo por la imposibilidad social que eso representaba, sino por carecer del estado de mente necesario. Piénsese que el concepto del flâneur, además de contener la idea poética de deambular rodeado por el anonimato, es de hecho, un lujo, en el sentido que es algo 
adicional. Es decir que uno solamente se lo puede permitir cuando ha cubierto todas las demás necesidades. En otras palabras, Carola puede ir caminando hasta su café o taberna favorita, lo que ya es muy atrevido, pero no puede flâner, le falta al personaje y al texto una dimensión poética para que esto sea posible. Dentro de su anonimato, el flâneur está liberado de todo su entorno y Capmany, que siempre ha hecho prueba de una consciencia política aguda, no puede prestar a Carola un paseo de flânerie. Sus pasos no son ritmados por la poesía de Barcelona, sino por la presencia política de su historia. El barrio donde nació, el convento, su novio anarquista, su experiencia de criada, su situación de prostituta y su condición de mujer la arraigan a una realidad político histórico donde la poesía no tiene lugar. De hecho, esta realidad es lo que forma la arquitectura del texto, del principio al final, y también la línea temática del discurso.

Ante lo expuesto resulta evidente que Carola es una mujer atípica que sale sola a caminar y frecuenta lugares "prohibidos" para las mujeres. Lo notable es que la toma de posesión del espacio masculino, se hace a través de la feminización progresiva de los cafés y bares de la ciudad. La escritura de Capmany no se deja por lo tanto detener por las barreras de la sociedad patriarcal que mantienen a la mujer en el hogar permitiendo sin embargo al hombre terminar su jornada de trabajo en el bar del barrio. En la novela de Capmany, los bares y los restaurantes se convierten así en un lugar transgresivo. Es a través de esa toma de territorio de Carola que la apropiación de la mujer del espacio urbano se nos muestra de manera más evidente. Ahora bien, Capmany va aún más lejos puesto que el bar donde Carola suele ir no es para ella solamente un lugar donde tomar algo sino un lugar de encuentro. En la taberna de Quim, descrita como un espacio absolutamente masculino y proletario ["Las taules de marbre rectangulars acollien 
sempre la mateixa gent, botiguers i manobres de Sant Gervasi, i a la tarda del dòmino petava sobre el marbre" (165)], es donde Carola se encuentra con un amigo para hablar de temas que poco tienen que ver con su condición de mujer, por lo que la taberna, tiene para Carola la misma función que para un hombre. Es el lugar público, donde reunirse para comer, tomar tragos y charlar. La inclusión y la relevancia de este espacio en el relato resulta totalmente lógico, puesto que, al compartir Carola con la ciudad el protagonismo de la novela, no es posible omitir ese microcosmos del mobiliario urbano que, sin ninguna duda, es uno de los territorios urbanos más hostiles que las mujeres tuvieron que conquistar.

La taberna d'en Quim ilustra perfectamente la teoría del cronotopo de Mijail Bajtin, ${ }^{25}$ es decir cierta relación tiempo-espacio (los sábados en la taberna) como elemento imprescindible para el desarrollo de una determinada acción. En la taberna, Carola y su amigo, el doctor Subietas, escapan respectivamente a la tutela de su amante y de su esposa disponiendo de un tiempo y de un espacio en el que mantener unas conversaciones al margen de sus respectivas condiciones. En toda la novela, el dialogismo sólo ocurrirá en esta taberna y entre ellos dos, siendo un espacio/tiempo que permite un juego polifónico en el que se expresan las creencias androcéntricas contrapuestas a la manera de pensar y de actuar de Carola.

Otra característica, que me parece oportuno añadir al cronotopo de la taberna es la teoría también bajtiana de la carnavalización. La descripción de la fealdad del doctor: “[...]vaig trobar al davant l'home més estrany i més lleig que ningú pugui imaginar.[...] i el somriure feia encara més tétrica la seva cara $[\ldots]$ soc inofensiu, malgrat aquesta cara perversa que la lletjor em procura.[...] La cara creixia tot acostant-se, avanzava el nas 
molsut, el llavi de doble plec que vessava," (187) y más adelante: “[1]a rialla li donava una expressió diabólica, la boca es recollia tibant a cada costat, les dents sortien, el nas vibrava i els ulls brillants expressaven un plaer immens immediat i intel-ligent" (189), evoca una máscara grotesca y hasta de horror. Además, del "disfraz", nos encontramos también ante un acontecimiento ritual que, en vez de ser anual como el carnaval, es semanal (cada sábado), pero con la misma circularidad temporal, siempre envuelto de un tono festivo en el que los dos participantes pueden subvertir sus papeles. De este modo, él, un hombre acomplejado y tímido hasta el punto de haber optado por ser un médico forense para no asustar a sus pacientes, puede aquí, sin pagar (como lo hace con las prostitutas), hablar con una mujer de una belleza excepcional. A su vez, ella deja de ser una mercadería sexual para convertirse en una persona con opiniones y decisiones propias. En estos encuentros, lo que destaca es la oposición entre dos extremos estéticos, dos máscaras, la de la fealdad y la de la belleza, dos entidades antagónicas que funcionan gracias a su propia oposición, como en el mito de "La belle et la bête." Una escena carnavalesca en la que lo que no sería posible en la calle se vuelve posible dentro del cronotopo de la taberna dando lugar a un dialogismo de efectos subversivos. Como es sabido, la noción bajtiana de la carnavalización es una manera particular de ver el mundo, marcado por la libertad y la risa, pero sobre todo por esa tendencia a invertir los códigos y valores, por poner el mundo al revés mezclando lo serio y lo cómico, lo alto y lo bajo, lo sublime y lo vulgar, la fealdad y la belleza, pero también lo culto y lo inculto. De ahí que los personajes sean un hombre de gran cultura y una mujer cuya cultura es cuestionable, ambos inmersos en un entorno profundamente catalán y popular ajeno a la oficial cultura castellana de la España de la época. Ahora bien, las conversaciones en la 
taberna solamente se llevan a cabo mientras Carola es una mantenida, la boda con Esteve Plans cambia drásticamente su vida de tal modo que pasa de ser una fulana de lujo a una burguesa aburrida, pero para mi lectura de la novela son los espacios barceloneses en los que se mueve Carola a partir de ese momento lo realmente importante.

Cuando Carola se casa con Esteve, dejan el piso de la calle Fontanella para ir a vivir a la que entonces se llamaba la calle Claris y ahora es la Vía Laietana (229). En pocas palabras la familia Plans es representante de una clase social que ocupaba los edificios de un sector de Barcelona anterior a la gran transformación urbanística que supuso la construcción de la vía Laietana. ${ }^{25}$ Los datos urbanísticos e históricos que nos da Capmany son bastante numerosos, aunque sucintos por lo que, si bien puede leerse la novela sin referencias, se pierden las implicaciones ideológicas y estéticas. Para verdaderamente entender el mensaje de Capmany, creo pues necesario pasar de una lectura básica del texto a una comprensión del discurso velado que cubre todos los significantes manipulados. Para pasar del uno al otro, tenemos que postular primero la existencia de un sujeto implícito (Capmany) que construye el texto en un acto enunciador afirmativo de la verdad axiológica del texto. Barcelona representa el eje central del movimiento temático general de la novela y Capmany la recupera paso a paso, recorriendo todo la ciudad desde la parte baja al alta. Pero también recupera Barcelona a través de su historia, de su urbanización, el texto lugares simbólicos, el arco de Triunfo, la Plaza Catalunya, el monumento a Colón, Can Xifré (actualmente el emblemático restaurante de las 7 portes) o la iglesia de la Concepció. Edificio gótico que se encuentra en medio de la modernidad del Eixample. A finales del siglo XIX las autoridades decidieron trasladar piedra a piedra el antiguo convento de Santa Maria de Jonqueres a 
esa nueva parte de la ciudad de Barcelona, en vez de derribarla. Ésta última mención de la autora sobre una de las particularidades arquitectural propia de Barcelona, en el cual el modernismo se mezcla al gótico y que es también un ejemplo en el cual vemos como la burguesía se apropia de los espacios manipulando a su antojo el patrimonio barcelonés. En su libro La Barcelona literaria, Carles Carreras indica que con la Vía Laietana empezó lo que llama una mala conciencia, "Primer fou l'obertura de la "gran via" Laietana, projectada ja per Ildefons Cerdà i empesa per Ángel Baixeras, la qual originà la primera mala conciencia ciutadana per la destrucció que provocava d'obres d'art i de passat històric; una mala consciència que ajudà que després de la destrucció s'escampessin alguns edificis gòtics per altres sectors de la ciutat, com la iglesia de Montsió i de la Concepció a l'Eixample [...]" (134).

Desde su piso del Eixample, y a pesar del encierro en que la mantiene su vida de burguesa, Carola sigue los cambios que se producen en la ciudad, y es desde allí que presencia la proclamación de la Segunda Republica. Otra vez, en el texto, se marca la fuerte oposición entre las clases sociales, frente al ruido, la ebullición, la alegría del pueblo hay el silencio, la huida y la aprensión de la burguesía representada por toda la familia Plans. Temerosos de posibles represalias todos los Plans deciden salir de la ciudad hasta que la situación se normalice, sin embargo Carola se queda y vuelve a sus caminatas por la ciudad sintiendo, al igual que Barcelona, un nuevo aire de libertad a su alrededor, pero este sentimiento dura poco, pues los Plans regresan y se inician las intrigas que producirían el levantamiento del ejército.

El 17 de julio de 1936 estalló la Guerra Civil y los tres días que siguieron fueron un infierno para Barcelona, hasta que los obreros y las fuerzas leales dominaron a la 
guarnición sublevada, a esto siguió la quema de los conventos, después vinieron los bombardeos cuyo primer blanco fue el puerto, si bien el propósito de la aviación era la población civil como táctica para sembrar el terror y el desaliento. Ahora bien, Capmany no menciona el 17 de julio, aunque sí habla de sucesos que acaecen en la vida de Carlota el 10 de julio. Esa elipsis le da fuerza de metalepsis por decir con esa figura de estilo lo que no nos dice explícitamente el relato. Barcelona ayuda una vez más a llenar los silencios y sabemos del inicio de la guerra a través del recorrido de la protagonista por la ciudad: 'No vaig arribar a la via Laietana. En arribar a la plaça d’Urquinaona, vaig haver de tombar pel carrer de Fontanella. Va ser llavors que vaig veure els balcons del nostre antic pis, oberts de bat a bat i a terra, a la voravia, l'immens armari mirall estavellat [...] El carrer tenia un aire de festa major [...] Els homes armats ens feien circular i em vaig trobar a la plaça de Catalunya" (245). En este día fatídico, Carola no puede llegar a su destino y todos los rodeos que tiene que hacer la llevan a la plaza Catalunya, plaza céntrica y punto de unión entre el núcleo viejo de la ciudad y el Eixample, entre la Barcelona proletaria y la burguesa, entre el pasado y el futuro. Carola se sitúa en el presente sin entender lo que está pasando y sigue caminando a pesar del peligro de las balas: "Jo sentia xiular las bales, però no pensaba que em podrien matar $[\ldots]$ només estava furiosa perquè aquell imbècil d'en Miquel se n'aniria sense mi” (246). Y con una mise en abîme, directa y casi acusadora, la voz narrativa menciona que este personaje es recurrente en las novelas de guerra: "[...] la doneta tossuda que travessa la ciutat, sota una pluja de bales, absent de tot el que passa al seu voltant, preocupada només del seu petit problema [...]"(246). Nos encontramos aquí ante una crítica severa a la indiferencia de la mujer frente al mundo político. Un campo del que Capmany considera que la mujer 
está ausente y que precisa conquistar. En su conclusión, la voz narrativa insiste en este punto terminando la cita con: "Però no és un símbol, és una realitat que persisteix." (246)

Al igual que al proclamarse la Segunda República, al estallar la guerra, Carola también queda sola en Barcelona. Su casa es requisada y convertida en hospital, es entonces cuando conoce a Benito Garrido al que considera el gran amor de su vida, un joven capitán anarquista con el que colabora hasta el final de la guerra. Se puede decir que Benito es un reflejo de Feliu, su amor de juventud, pues como él, Benito pertenece al mismo estamento social, tiene una retórica revolucionaria, gusta de la lectura, ama sin ser posesivo... Ahora bien, al igual que con Feliu, la relación tiene un desenlace trágico, pues Benito no regresa del frente. El 20 de enero 1936, cierran el hospital y en este acontecimiento nos encontramos con otra metalepsis al no decírsenos que los nacionales entraron en Barcelona el 26 de enero y que los republicanos habían perdido la guerra. Carola, en osmosis con Barcelona, se siente derrotada acabada, abandona su casa y, temerosa de que su familia le haga pagar caro su alianza con los republicanos, se esconde de ellos perdiéndose entre los vencidos (el pueblo). Es decir, abandona la Barcelona de los "vencedores," y regresa a Ciutat Vella, el barrio de su niñez, el de la gente humilde, pero su marido la encuentra y la obliga a regresar con él. A partir de este momento Barcelona desaparece de la vida de Carola, quien después de su fracasado intento de suicidio y de un periodo en el que vive como una autómata, termina por escapar de ese ambiente asfixiante y huye a París, allí Carola cambia nuevamente de identidad y vuelve a ser dueña de sí misma.

Como hemos podido observar, Feliçment, jo sóc una dona superpone la historia de la protagonista con la de Barcelona entre los años 1900 y 1950. El relato se edifica 
como una ciudad; no se lee, se visita, lo descubrimos siguiendo los pasos de la protagonista. La construcción del texto, en patchwork puede leerse como un recorrido al azar, sin seguir un plan lógico, pero termina dando un mapa "real" de la ciudad histórica y geográfica de Barcelona. Vamos de tema a tema como de calle a calle, la sensación de perderse o recorrer la misma calle es constante en la lectura y traduce el juego de la memoria, donde un recuerdo llama a otro. Tiene en ese sentido una expresión casi oral y la proyección de Barcelona claramente dividida en clases sociales legitima su conciencia de clase y su solidaridad con el proletariado.

Por otro lado, la toma de conciencia de la palabra se acompaña de una verdadera apropiación femenina del espacio urbano. La experiencia de la palabra se une a la experiencia del espacio que deja de ser propiedad exclusiva del hombre de manera que la ciudad como espacio masculino se va feminizando. Esta cultura de lo femenino que se construye alrededor de una misma lengua es más que un discurso, se convierte en un lenguaje. La ciudad es un cuerpo parlante y este hablar a través de la voz de una mujer la hacen existir. El resultado, es que Barcelona no sólo es un instrumento al servicio de la escritura de Capmany, sino que se hace cosa, se vuelve cuerpo, protagonista. El catalán representa, para todos estos personajes de la novela y para la autora, los cimientos que sostienen y unifican el texto, pero es una unión no sólo lingüística sino también de identidad. Barcelona frente al estado español que representa la desposesión de la cultura y de la identidad catalana construye no sólo una lengua-cuerpo, sino también una lengua identidad y su reivindicación es totalmente nacionalista.

Ante lo expuesto, es lógico comprender que, en el momento de su producción, el relato de Capmany deba de ser palimpséstico y que la metalepsis sea una manera de 
disfrazar su discurso, lo cual, sólo puede ser comprendido por lectores atentos poseedores de un cierto conocimiento de la ciudad que estén dispuestos a leer entrelíneas. Con Feliçment, jo sóc una dona, Capmany establece una relación entre ella y el lector invitándolo a un juego en el que cada indicio lleva a otro hasta desmantelar y deconstruir la historia oficial del franquismo. 


\section{NOTAS}

1 Esquerra Republicana : Esquerra Republicana de Catalunya: (abreviado tradicionalmente ERC y de forma oficial Esquerra) (Izquierda Republicana de Cataluña en castellano), es un partido político fundado en Barcelona (España) en 1931 con presencia en Cataluña y actualmente también con presencia, minoritaria, en la Comunidad Valenciana (como Esquerra Republicana del País Valencià), Islas Baleares y en el Rosellón francés. De ideología independentista catalana, aunque originariamente federalista, apuesta por la independencia de los territorios de lengua catalana, los Países Catalanes. "Esquerra_Republicana_de_Catalunya."

${ }^{2}$ Generalitat republicana/Segunda república: 1930. Dimisión de Primo de Rivera. Pacto de San Sebastián entre republicanos, socialistas y nacionalistas catalanes.

1931. Fundación de Esquerra Republicana de Cataluña.

Proclamación de la República Catalana y de la República Española.

En Cataluña se somete a plebiscito el Estatuto de Autonomía.

1932. Insurrección anarquista en el Alto Llobregat y en el Cardaner.

Las Cortes republicanas aprueban el Estatuto.

Se promulga el derecho de sufragio de la mujer. Carme Karr, presidenta de Acción

Femenina, es una de sus grandes reivindicadoras.

1933. Victoria de la derecha en las elecciones a las Cortes.

Las mujeres votan por vez primera.

Muere Francesc Macià. Lluís Companys le sucede en el cargo de presidente de la Generalitat.

1934. Lluís Companys proclama el Estado Catalán dentro de la República Federal

Española.

Encarcelamiento del gobierno catalán.

1935. Suspensión definitiva del Estatuto.

1936. Victoria del Frente de Izquierdas en las elecciones.

Restablecimiento de la autonomía y de la Generalitat.

Golpe de estado militar: inicio de la guerra civil. "Generalitat Republicana". Museu

d'Història de Catalunya. La memoria de un país. n.p, n.d, Web. 20 Sept.2011.

${ }^{3}$ Premio Joanot Martorell: El Premio Sant Jordi de novela es uno de los premios literarios más prestigiosos en lengua catalana. El premio es convocado por Enciclopedia Catalana y Òmnium Cultural, y patrocinado por Edicions Proa, que publica la obra ganadora. El premio fue creado en 1947 por la Editorial Aymá. Entre 1947 y 1959 fue denominado Premio Joanot Martorell. La entrega del premio se hace en una gala que tiene lugar en Barcelona la noche de Santa Lucía, en el mes de diciembre. El autor de la obra ganadora recibe un premio en metálico de 60.000 euros, además de la publicación de la obra. "Premi_Sant_Jordi_de_Novela."

${ }^{4}$ En su estudio La Condició De La Dona En La Narrativa Femenina Catalana Charlon explica que, Fins els anys 50, amb el relatiu relaxament de la supressió del català, Capmany no va publicar cap de les serves obres escrites, encara que el 1948 la seva novel.la, El cel no és transparent guanyà el prestigiós Premi Joanot Martorell. Aquest 
manuscrit va ser rebutjat per la censura oficial i solament es va publiar el 1963

pel Club Editor de Barcelona amb el nou títol La pluja als vidres. Durant aquesta dècada gosà publicar novel.les de resistència i crítica social disfressades de novel.les històriques o de ficciones especulatives. (314)

${ }^{5}$ Una influencia que casi desapareció durante la Segunda República, la Iglesia regresó a su lugar de poder con un Concordato que regularizó sus relaciones con el Estado español: "In 1953 a Concordat was signed between Spain and the Vatican, thus ensuring further collaboration between the Catholic Church and the Spanish State." (Davies, 174). La iglesia patriarcal imponía reglas estrictas sobre las mujeres, controlaba su educación y sobre todo, servía como su 'confesor'.

${ }^{6}$ El código civil Napoleónico de 1889 declaró al esposo como el representante legal de la mujer hasta su muerte, haciendo de ella un ser totalmente dependiente. Además, bajo Franco, se eliminó el divorcio, y se limitó la propaganda y la disponibilidad de la anticoncepción (Carbayo Abengózar 34), aumentando así la posibilidad de la mujer ser madre. El Régimen franquista excluía a las mujeres de muchas actividades sociales y las mantenía en roles tradicionales. La Iglesia Católica fue la principal defensora de las pautas sociales establecidas por el Régimen. (Davies, 6).

${ }^{7}$ El Second Empire fue el régimen imperial bonapartista de Napoleón III que duró de 1852 a 1870, entre el segundo y el tercer gobierno republicano francés.

8 Capmany hubiera podido traducir la palabra francesa "heureusement" por "sortosament" que es más catalana, pero esta última traducción no hubiera tenido el mismo significado.

${ }^{9}$ Como señala Todorov, en Memoria Del Mal, Tentación Del Bien: Indagación Sobre El Siglo $X X$, en los "regímenes totalitarios del siglo XX revelaron la existencia de un peligro antes insospechado: el de un completo dominio sobre la memoria" (159).

${ }^{10} \mathrm{La}$ industrialización que tuvo lugar a finales del siglo XIX y principio del siglo XX hace que se establezcan en San Andrés empresas importantes, como la fábrica textil Fabra y Coats, la Maquinista, Fabricación Nacional de Colorantes, y una gran cantidad de empresas pequeñas y de talleres. "San Andrés de Palomar".

11 Michel Laronde aplica esta expresión a los inmigrantes que siempre se sienten vigilados por las autoridades del país de acogida.

${ }^{12}$ L'existència d'una Presó de Dones al barri de les Corts, sobre els terrenys on avui s'aixequen els coneguts magatzems de El Corte Ingles-Diagonal, és probablement encara una dada desconeguda per molts barcelonins, ja que les iniciatives de recuperar la memòria històrica de la repressió no han incidit especialment en aquest complex penitenciari que va estar actiu entre 1936 i 1955. L'origen d'aquesta presó el trobem però, en els primers mesos de la Guerra Civil quan l'antic Asil del Bon Consell, que s'aixecava en l'antiga finca de Can Duran en una zona de la Diagonal encara poc urbanitzada, va ser 
incautat per la FAI a l'octubre de 1936. L'Asil del Bon Consell s'aixecava sobre l'antiga finca de Can Duran (també anomenada Can Feló) al nord del barri de Les Corts en el camí que conduia cap a Sarrià. A la finca hi havia una masia medieval, que la família Duran havia ampliat afegint-hi un gran edifici en el que hi destacaven una torre i una capella. Tot el conjunt era envoltat per grans extensions d'hortjardins. A mitjans del segle XIX, la finca passà a mans del canonge Josep Morgades, que el 1886 va encarregar a les monges dominiques franceses de l'orde de la Presentació la gestió del recinte, que fou destinat a una triple funció: Asil per a joves de mala reputació, col-legi per educar en la fe catòlica a nenes orfes o abandonades i pensionat. Una benefactora de l'asil fou la senyora Dorotea de Chopitea que va sufragar l'ampliació de l'edifici. L'Asil del Bon Consell de Les Corts va mantenir la seva activitat fins a l'octubre de 1936, mesos després de començar la guerra civil, quan els milicians de la FAI varen incautar l'edifici que s'acabaria convertint en la Presó de Dones de Les Corts."Presó de Dones al barri de les Corts (1936-1955)". Inventari de la Barcelona desapareguda. Barcelofilia. 2 Jul 2011. Web 7 Sept. 2011.

${ }^{13}$ El monasterio de Sant Pere de les Puelles es un antiguo monasterio benedictino situado en la ciudad de Barcelona (España). En la actualidad sólo se conserva su iglesia. La comunidad sufrió la exclaustración en 1835 y el monasterio se convirtió en prisión. En 1879 , la comunidad de monjas se trasladó a un nuevo emplazamiento en el distrito de Sarrià-Sant Gervasi en el que todavía residen. En 1873 se desmontó el claustro así como otras dependencias. El monasterio sufrió un incendio en 1909 (semana trágica) tras el cual fue reconstruido.

"Monasterio de Sant Pere de les Puelles". Wikipedia: The Free Encyclopedia. Wikimedia Foundation, Inc.. 16 abr 2011.Web. 12 Nov 2011.

${ }^{14}$ La Semana Trágica, de Barcelona es el periodo comprendido entre el 25 de julio y el 1 de agosto de 1909. Fue la guerra de Marruecos, la que determinó el estallido de la SemanaTrágica: los ataques de los habitantes del Rif contra los trabajadores españoles de una compañía minera llevó a la movilización de reservistas. Las protestas obreras pronto aparecieron en Barcelona y Madrid. El día 26 de julio estalló la huelga general en Barcelona, convocada por Solidaridad Obrera y la UGT. Se iniciaron tres días de protestas, quemas de conventos, enfrentamientos con el ejército. La Semana Trágica tuvo un brutal coste humano: un centenar de muertos, heridos, destrucciones... La represión fue muy dura y culminó con el juicio sin garantías y la ejecución de Francisco Ferrer y Guardia, pedagogo anarquista y fundador de la Escuela Moderna. Regeneracionismo y revisionismo político. Las crisis de 1909 y 1917. La guerra colonial en Marruecos. El desastre de Anual. "Regeneracionismo y revisionismo político. Las crisis de 1909 y 1917. La guerra colonial en Marruecos. El desastre de Anual." HistoriasigloXX.org. El sitio web de la historia del siglo XX, 2005. Web 12 Nov. 2011.

${ }^{15}$ El 1 de marzo de 1877 circuló el primer tranvía a vapor, en la línea de Sant Andreu de Palomar. El 26 de enero de 1899 se estrena el primer tranvía eléctrico, únicamente en una de las dos vías de la popular línea 29. La primera reacción popular estaba marcada por las leyendas urbanas acerca de la seguridad del sistema. El miedo se diluyó con la 
experiencia práctica. Gonzalez Massip, Albert. "Tranvías de Barcelona S.A. Historia". Tramvia.org. n.p, 26 Oct.2006. Web. 13 Oct. 2011.

${ }^{16}$ En el límite norte del municipio de Sant Martí, del barrio de Poble Nou, que por extensión llegaba hasta la Riera d'Horta, se formó a partir de 1870 un pequeño barrio de barracas, que recibió el nombre de Pekín. Según la tradición, el origen de la barriada y el de su nombre proviene del hecho de que sus primeros habitantes fueron una colonia de chinos cantoneses que llegaron maltrechos a su costa después de un largo viaje desde Cuba y allí mismo se instalaron con los restos del naufragio. El modesto barrio fue creciendo con la llegada de inmigrantes para la Exposición Universal de 1888 y de pescadores expulsados de la Barceloneta. Las barracas se distribuían a lo largo de la calle San Salvador, allí con el tiempo también se les construyó una iglesia, que sería incendiada durante la crema de conventos de la "Semana Trágica". Como todos los otros barrios al lado del mar, Pequín estaba expuesto a sus temporales que periódicamente azotaban sus humildes barracas, especialmente duros fueron los de los años treinta. A partir de estos años, un poco más allá, pasada la Riera d'Horta, ya en el vecino Sant Adrià, se fue conformando otro barrio de barracas al lado del castillo militar "de las Cuatro Torres," el Camp de la Bota, que aún perdura en la memoria popular. Bou, Xavier. "Las barracas del Campo de la Bota.". Xavier Bou: El último viaje a Icaria, elultimoviajeaicaria, 7 April 2011. Web. 4 Nov. 2011.

${ }^{17}$ Berga. Com a fets destacables del segle XX, cal fer esment de la revolta anarquista de Fígols, el 1932, que s'estengué a altres poblacions de la comarca. Els grupuscles anarquistes també varen protagonitzar collectivitzacions $\mathrm{i}$ episodis violents durant la guerra civil. "El Berdegà.Història". xtec.cat. n.p, 12 May 2002. Web. 18 Dec. 2011

Otro hecho muy interesante sobre Bergà es que acaba de declarar persona non grata al rey Juan Carlos. "El Juan Carlos no es Rey "como resultado de un proceso democrático, sino justo lo contrario, como consecuencia de la herencia dictada por su antecesor Francisco Franco", señalan los impulsores de la moción." "El rey, "persona non grata" en Berga, Barcelona”. larepublica.es. Republica. 4 May. 2012. Web 5 May 2012.

${ }^{18}$ De hecho, esta imagen de dos amantes leyendo juntos recuerda, a cierto nivel, el Infierno de Dante $(\mathrm{V}, 131)$ Paolo y Francesca leen juntos Lancelot. El amor está definido como un doble abrazo: el de la lengua, de las palabras y el del silencio, del secreto. Es el abrazo del lenguaje sumiso al silencio. En esto reside el lazo entre la experiencia del amor como lo es él de la lectura. Es como una sorpresa de esta mediación sobre el amor. Experiencia del amor, aquí prohibido y experiencia de la lectura, también prohibida, en una misma lengua privada interpretado por la autoridad como palabras de traición y desembocando en la muerte de Feliu por manos de la autoridad.

${ }^{19}$ Gustave Courbet, (Ornans, Francia, 10 de junio de 1819 - La Tour-de-Peilz, Suiza, 31 de diciembre de 1877) fue un pintor francés, fundador y máximo representante del realismo. También fue un comprometido activista democrático, republicano, cercano al socialismo revolucionario. 
${ }^{20}$ Barcelona, la ciudad de las pistolas: La vida política de Barcelona fue violenta a finales de siglo XIX por las acciones terroristas del anarquismo (Barcelona era conocida como la ciudad de las bombas). Más violento fue el principio del siglo XX, especialmente durante los años transcurridos entre 1919 (la huelga de la Canadiense) hasta 1923 (la llegada al poder de Miguel Primo de Rivera). Son los años del pistolerismo, es decir, el enfrentamiento violento entre el Sindicato Único (la CNT) y el Sindicato Libre, controlado por la patronal y utilizado por el Gobernador Militar de Barcelona, el General Martínez Anido para luchar contra el sindicalismo obrero. Mestre Chust, José Vicente. "El pistolerismo en la Barcelona de principios de siglo XX". Suite 101.net. n.p, 7 May 2010. Web. 10 Oct. 2011.

${ }^{21}$ La recuperació cultural i lingüística catalana: Suport a l'Institut d'Estudis Catalans, aplicació de les normes ortogràfiques de Pompeu Fabra. La Lliga Regionalista tindrà al 1917 alguns dels seus membres en el govern, entre ells Francesc Cambó que va arribar a ministre. Dos anys després, al 1919, s'elabora un projecte d'Estatut per a Catalunya que va ser presentat a les Corts de Madrid. L'oposició de la majoria de la classe política espanyola no va permetre la seva aprovació. Alarcó Vicent, José-Manuel. "La Mancomunitat de Catalunya". Historia Catalunya i Espanya: Segles XIX i XX . n.p, 25 May 2005. Web 19 Oct. 2011.

22 El pensamiento de Luce Irigaray resume la teoría feminista que establece que originalmente la mujer como hija de su padre, luego esposa de su marido, sea reconocida como un valor de cambio entre hombres, una mercancía "passant d'un propriétaire à l'autre, d'un consommateur à l'autre, possible monaie d'échange entre l'un et l'autre" (632). Esta tesis de la mujer mercancía recuperada por las feministas no se limita a la prostitución, sino que se extiende a la condición de la mujer en general. El análisis marxista de la mercancía como forma elemental de la riqueza capitalista es aplicado por los feministas en la sociedad patriarcal. Es decir que la mujer y la mercancía llevan valores de propiedad, de productores, explotadores y explotados, alrededor de los cuales, según Karl Marx, se edifica la sociedad capitalista.

${ }^{23}$ Café restaurante Maison Dorée en Plaza Cataluña 22, obra de August Font i Carreras. En 1897 los hermanos G. y M. Pompidor "fondistas" de Tarrasa de ascendencia francesa inauguran la Maison Dorée. Pronto se convirtió en el establecimiento de más clase y calidad de la ciudad. Este establecimiento fue uno de los restaurantes más lujosos y suntuosos de Barcelona, un restaurante con clase que acogió a toda la intelectualidad barcelonesa hasta 1918. "Barcelona 1903, Maison Dorée, Café Restaurant1918...". mtvo.lasmentiras. n.p, 2009. Web. 25 Sept. 2011.

${ }^{24}$ Nada (1945) de Carmen Laforet es una novela autobiográfica que tiene lugar durante los primeros años de la Posguerra. La protagonista, Andrea, de dieciocho años, deja su pueblo y va a estudiar a Barcelona, donde vive con sus parientes. Al final de la novela, se ira con su amiga a Madrid, porque Barcelona no puede ofrecerle nada. La novela escrita en castellano, ganó el Premio Nadal el 6 de enero de 1945. 
${ }^{25}$ Via Laietana: es una calle de Barcelona que comunica el Ensanche con el puerto atravesando la Ciutat Vella. Su nombre está dedicado a los primeros habitantes íberos de la zona. Fue diseñada inicialmente por Ildefonso Cerdá en 1859 para enlazar de forma directa el nuevo barrio del Ensanche, que se perfilaba dentro del plan Cerdá con el puerto, vía de comunicación principal en el siglo XIX. Pero el Plan Cerdá se centró en el crecimiento fuera de las murallas y no fue hasta 1899 que se volvió a impulsar con la aprobación del Plan de Reforma Interior de Ángel Baixeras. La entrada política de la Lliga Regionalista de Francisco Cambó, la demanda de comunicación de la burguesía instalada en el Ensanche y la preocupación por controlar los alborotadores dentro de una red densa de calles, hizo recuperar el proyecto en 1907. Con la construcción de la Via Laietana: 2.199 viviendas se derribaron y 82 calles desaparecieron totalmente o parcialmente con el coste social que todo ello supuso. La Via Laietana significó el desmenuzamiento de la unidad urbanística del centro histórico en dos mitades diferenciadas: por una parte el Barri Gòtic y por la otra los barrios de Sant Pere, Santa Caterina y la Ribera. "Via Layetana". Wikipedia: The Free Encyclopedia. Wikimedia Foundation, Inc..15 May. 2011. Web. 17 febr. 2012. 


\section{Capítulo IV}

\section{Habíamos ganado la guerra}

Lo que el señor Pla ignoraba es que una señora del Ensanche no es igual a otra señora del Ensanche, lo mismo que sus balcones. Y me alegré cuando, en la Habana, encontré los mismos hierros historiados, con dragones o motivos florales: los cerrajeros allí eran catalanes. (Dime que... 153)

Esther Tusquets i Guillén nació en Barcelona el 30 de Agosto de 1936 y falleció el 23 de julio de 2012 en su ciudad natal. Su familia pertenecía a la alta burguesía barcelonesa, sobre todo por su lado paterno (familia de banqueros). Su padre, Magín Tusquets, era médico y según ella, un hombre raro y atípico, un buen burgués de derechas y franquista. Su madre de nivel social más bajo y de familia más liberal fue obligada a casarse con él por su situación acomodada.

Tusquets se licenció en historia a los 23 años y por un tiempo impartió clases de literatura e historia en una academia hasta que, en los años sesenta, su padre compró una editorial familiar religiosa y ultraconservadora, y le propuso a Esther que fuera ella quien la dirigiera. Esta la transformó totalmente convirtiéndola en la prestigiosa Editorial Lumen, que dirigió por 40 años, hasta la muerte de su padre. Pero Esther Tusquets, además de ser, como la definiría Carmen Balcells, una gran señora de la edición, ${ }^{1}$ también fue una de las escritoras españolas en lengua castellana más destacadas de la 
segunda mitad del siglo XX. Tusquets pertenece al grupo de escritoras que, al igual que Montserrat Roig, Rosa Montero, Carme Riera, Ana $\mathrm{M}^{\mathrm{a}}$ Moix, Lourdes Ortiz, Soledad Puértolas y Núria $\mathrm{Amat}^{2}$ empiezan a publicar a partir de los años setenta. Un grupo de escritoras que, según Geraldine Nichols, a pesar de los numerosos premios que recibieron y el gran número de libros que vendieron, no fue verdaderamente valorado porque la crítica literaria de su tiempo estaba regida por la prepotencia patriarcal de siempre y a los críticos no les parecía significativo o atrayente el microcosmo narrado por las mujeres, ese mundo pequeño y tan criticado por su temática intimista.

La primera novela de Tusquets aparece en 1978, El mismo mar de todos los veranos, que se consideró como la primera novela amoral de la nueva literatura española. Es decir, que fue una novela escrita al margen de los valores morales de una sociedad que apenas salía del franquismo. La novela no solo trata de una relación amorosa entre dos mujeres, sino que también condena las nociones de familia, matrimonio, maternidad y el papel asignado a la mujer en la sociedad patriarcal. Esta primera novela inicia una trilogía que continúa en 1979 con El amor es un juego solitario, ganadora del Premio Ciudad de Barcelona, y termina con Varada tras el último naufragio en 1980. En 1981, Tusquets publicó relatos o novelas breves con la obra Siete miradas en un mismo paisaje, seguida por La conejita Marcela y Para no volver (1985), novela de relatos autobiográficos, en la cual Tusquets cuenta sus propias experiencias psicoanalíticas a través de la protagonista. A estos textos se añadieron Después de Moisés y La reina de los gatos y en 1997 publicó su libro de relatos La niña lunática y otros cuentos, texto que expone las dificultades en aceptar las diferencias de los otros. 
A partir de 2000 escribió memorias y narraciones autobiográficas; Confesiones de una editora poco mentirosa (2005) Habiamos ganado la guerra (2007) y Confesiones de una vieja dama indigna (2009). En febrero pasado presentó con su hermano, el arquitecto Óscar Tusquets, Tiempos que fueron (2012), un libro de memorias en forma de diálogo entre los dos hermanos, en el que hablan de su vida privada, familiar y profesional. En sus memorias, Tusquets penetra en el mundo cultural de Barcelona de los años sesenta y setenta, extendiéndose especialmente en su relación con figuras de la 'gauche divine ${ }^{\prime 3}$ como Carlos Barral, Luis García Berlanga, Ana María Matute, Pablo Neruda y Carmen Martín Gaite por citar a algunos.

En este trabajo me propongo analizar la visión de Barcelona a través de la narrativa autobiográfica de Esther Tusquets por varias razones. Una de ellas es que Tusquets nos describe la Barcelona de la posguerra del lado de los vencedores lo que, como lo menciona ella misma en la contracubierta de Habiamos ganado la guerra, "[...] se ha escrito mucho desde el punto de vista de quienes la perdieron, en libros de memorias y en literatura de ficción, pero me pareció que disponíamos de menos material procedente de los vencedores [...]. Creí que mi experiencia personal podía aportar algo.” Ese "algo" a la vez muy vago y prometedor es lo que me incitó a escoger su obra autobiográfica, ya que, además de un enfoque diferente al de las otras autoras estudiadas también ofrece una narrativa memorial. Su libro nos desvela mucho de la burguesía franquista catalana y de su visión o apropiación de Barcelona. Sin embargo, antes de profundizar el tema del espacio urbano en la autobiografía y de la visión que tiene Tusquets de esta ciudad, considero necesario aportar algunas precisiones sobre la escritura autobiográfica de mujeres. 
En su libro La novela femenina contemporánea (1970-1985) Biruté Ciplijauskaité, estudia el género autobiográfico femenino y empieza con un recorrido histórico de la escritura femenina a través de los siglos, explicando su evolución desde su comienzo hasta finales de siglo XX. "En sus principios, la prosa femenina se limita a Cartas y Memorias. La identificación es total; no se trata de usar la forma autobiográfica como la expresión de un personaje ficticio o de un narrador con vida propia. Por otra parte, las novelas femeninas de fines del siglo XVIII y principios del XIX adoptan modos de narración al uso corriente y no procuran crear un estilo original" (16). Para Ciplijauskaité, escribir de "modo personal" ha sido una de las características de la escritura femenina. Sin embargo, Donna Stanton ${ }^{4}$ es reticente a aceptar este rasgo como una característica general y explica que "se suponía" que las mujeres eran menos aptas a escribir ficciones y recurrían a sus experiencias personales para los temas y los personajes de sus obras (3). Las protagonistas de las novelas escritas por mujeres eran a menudo identificadas con la autora, lo que en sí constituía un replanteamiento de la calidad literaria de las escritoras. Por ejemplo, George $\mathrm{Sand}^{5}$ siempre afirmó no tener nada que ver con sus protagonistas y no creo que ella fuera la única autora en quejarse de que, por el mero hecho de ser mujer, se la identificara con las mujeres de sus novelas.

No obstante, la mayoría de las investigaciones sobre la escritura femenina concuerdan con el predominio de una narrativa en primera persona, sobre todo a partir del siglo XX. Siempre según Ciplijauskaité, con el feminismo de los sesenta, la escritura deviene una expresión de protesta y sobre todo de introspección. Las mujeres desean escribir como mujeres pero ya no como autobiógrafas sino como representantes de su género. Escribir en primera persona corresponde a una voluntad y una búsqueda de sí 
mismas. Lo que Elaine Showalter ${ }^{6}$ designa como el periodo de "autodescubrimiento", o búsqueda de identidad con "bajadas al subconsciente".

Al mismo tiempo, muchas escritoras prefieren no escribir sobre sus propias vidas lo que ha llevado a varias críticas estadounidenses como Estelle Jelinek, Stanton, Martine Watson Brownley y Allison Kimmich a estudiar esta problemática. Para ellas, hasta bien entrado el siglo XX, el acto de construcción identitario que implica exponerse al público resulta difícil para muchas mujeres. Por tener papeles complementarios en sus vidas familiares, profesionales y artísticas, las mujeres parecen tener más dificultades para reconstruir sus vidas según una teleología linear. Así que, afirmarse como escritora y hacer del proyecto de escritura un relato sobre sí misma queda, por mucho tiempo, un acto de transgresión que cuestiona de manera fundamental el confinamiento de la mujer en el espacio privado.

La relación que existe entre mujer y literatura es particularmente interesante en el contexto español del siglo XX por ser un caso excepcional en este siglo de emancipación para las mujeres. Mientras que por un lado, el contexto de la Segunda República española había puesto las bases de una emancipación política, social e intelectual para las mujeres, por otro lado la instauración del sistema franquista provocó una regresión fulgurante frente al contexto europeo de la época. A partir de 1939, España vive oficialmente cuarenta años de dictadura y muchas mujeres que habían empezado a emanciparse (aunque solo fueran una minoría) tuvieron que regresar al hogar. No obstante, paralelamente a toda una mitología que el franquismo elabora alrededor del concepto de "mujer", algunas de ellas pudieron encontrar en la literatura un espacio que les permitió formular un testimonio de su condición y, en algunos casos, incluso 
superarla. Es de notar también que, muchas de las novelas de la posguerra escritas por mujeres son en primera persona, como Nada (1945) de Carmen Laforet, que es una de las novelas más significativas de este periodo.

Otra particularidad dentro del mundo literario español es que, a pesar de una tradición literaria que ha mostrado una gran reticencia hacia la escritura personal, la publicación de autobiografías, memorias y diarios íntimos conoce un nuevo impulso en España desde $1975 .^{7}$ El fin del franquismo favoreció un proceso de reconstrucción histórico y personal en muchas escritoras. Sin embargo, esta moda autobiográfica se ha enfrentado a dos obstáculos propia a la idiosincrasia literaria española: por un lado escasez de autobiografías en las letras hispanas; por otro lado, el agotamiento del modelo tradicional del siglo XIX. Así las escritoras tuvieron que encontrar unas formas propias de expresión personal y adecuada a su época. En este corriente de subjetividad, resalta la importancia que ha ganado la autoficción en el panorama literario español. La ambigüedad en la identificación autora-narradora se ha convertido en una tendencia marcada en la producción literaria contemporánea. Como representantes de este género dentro del ámbito español podríamos citar a Carmen Martín Gaite, Ana María Matute, y las autoras catalanas Montserrat Roig, Teresa Pàmies y Maria Aurèlia Capmany que dan testimonios de su existencia, sin escribir lo que se podría llamar autobiografías puras.

Es necesario, entonces definir lo que se entiende por autobiografía "pura". Según Philippe Lejeune, ${ }^{8}$ el género autobiográfico se funda en un principio básico: "Il faut qu'il y est identité de l'auteur, du narrateur et du personnage" (15). Es decir que el género autobiográfico se apoye sobre el principio o la condición onomástica de la triple identidad, entre el autor, el narrador y el personaje. El hecho que el autor dé datos 
biográficos verdaderos no puede ser suficiente, es necesario que se establezca un acuerdo entre el autor y su lector. El primero (el autor) se compromete a decir la verdad, a ser honesto sobre su vida. En contrapartida, el segundo (el narrador) debe confiar en él. Este compromiso en el cual el autor afirma la identidad entre el narrador, el personaje y él mismo constituye lo que Lejeune ha llamado el pacto autobiográfico. Es decir, "l'affirmation dans le texte de cette identité, renvoyant en dernier ressort au nom de l'auteur sur la couverture" (22). Los estudios de Lejeune aportaron una dimensión cualitativa al género de la autobiografía, por establecer una definición precisa que permite reconocerla como género totalmente independiente. La autobiografía, como la biografía, es un texto referencial. Su fin no es lograr un efecto de realidad, como en una novela, sino lograr lo real. Por ejemplo, da informaciones que pueden ser verificadas. Este "pacto referencial", como lo llama Lejeune, es en general incluido en el pacto autobiográfico. El autor se compromete a dar una verdad tal como él la vio, o también puede mencionar problemas con su memoria, toda esta honestidad ayuda a establecer la confianza del lector.

El replanteamiento de la literatura moderna de la dimensión referencial del relato autobiográfico durante el siglo XX se revela favorable para las mujeres al abolir la linealidad del relato y la homogeneidad de la construcción identitaria del "yo" hablando. A partir de los años setenta del siglo XX, la crítica feminista americana ha tratado de detectar en la utilización del género autobiográfico de mujeres una escritura específicamente femenina, cuya esencia sería determinada por el carácter fragmentario de los textos y por su oposición formal y sustancial a una tradición masculina. Estas conclusiones han sido descartadas por su tendencia a la generalización. La realidad de los 
textos muestra que una variedad extraordinaria de estrategias de escritura depende del contexto histórico y cultural de su producción como de los proyectos de escritura individual. Es esta variedad la que la crítica favorece en sus trabajos más recientes.

Por lo tanto, ¿es legítimo tratar la autobiografía femenina como un corpus específico? Yo diría que sí, esencialmente por tres razones. Un acercamiento semejante permite, primero tomar en cuenta las especificidades de producción y de publicación de la escritura femenina, en particular de la autobiografía, hasta mediados del siglo XX, especificidades con una influencia irrefutable sobre las estrategias textuales. Segundo, existe un público cuyo modo de lectura de la autobiografía depende, en parte, de si el autor es hombre o mujer. A pesar de que muchos escritores refuten este hecho, y que en la literatura contemporánea, este acercamiento tienda a ser rechazado, nunca se podrá abandonar del todo. Mi tercera razón toca las temáticas autobiográficas que llevan un estatus diferente según el sexo del autor, y se puede incluir aquí diferentes identidades sexuales del "yo" hablante, dentro de las cuales podemos ver la experiencia de su propio cuerpo, la actividad sexual en su dinámica biográfica, la procreación y las relaciones intergeneracionales. Se puede objetar, como señala Bethany Ladimer, ${ }^{9}$ que las autobiógrafas pocas veces hablan de sus embarazos, y da el ejemplo de Simone de Beauvoir quien, hace hincapié en su decisión de escribir y su rechazo de la maternidad. Pero, pienso que el ejemplo no es válido, se trata aquí de una toma de distancia consciente en reacción a un discurso dominante que vincula estrechamente la identidad femenina a la maternidad.

Me parece relevante mencionar a la historiadora americana Joan W.Scott ${ }^{10}$ para quien lo que llamamos "experiencia" es, aun en sus dimensiones corporales e íntimas, un 
discurso, esencialmente elaborado por el contexto histórico y cultural en el cual está enunciado. La enunciación de las experiencias relacionadas a la identidad sexual incluye siempre una postura con respeto al discurso social correspondiente a la construcción cultural de la identidad sexual. Lejos de postular un esencialismo de lo femenino, Scott ve la feminidad construida en los textos como una dimensión identitaria que interactúa constantemente con muchos otros aspectos identitarios, que sean de orden cultural, social, religioso o étnico. Para reusar la metáfora de la crítica americana Shari Benstock, ${ }^{11}$ se trata de reconocer la construcción identitaria en el texto autobiográfico como una red constituida de múltiples hilos cuyos espacios vacíos son también parte integrante de este todo.

Si nos enfocamos ahora en la relación entre autora, narradora y protagonista en Habíamos ganado la guerra, de Tusquest vemos que no deja ninguna ambigüedad sobre el género de su narrativa y que cumple con el pacto narrativo que relaciona al lector con la autora. Otro estudio pertinente para este trabajo es La autobiografia de George May, 12 porque plantea la dimensión histórica en la autobiografía. El hecho de poder analizar el entorno histórico que rodea una autobiógrafa es interesante para el lector y lleva también un interés primordial en este trabajo, porque nos ayudará a examinar el espacio urbano que encierra esta narrativa. Se puede considerar que en las autobiografías los espacios presentan dos marcos narrativos. Primero, el lugar exacto donde ocurrieron los eventos descritos por la autora; segundo, el sitio desde el cual está escribiendo en el momento preciso. La exactitud del espacio en la narración autobiográfica, es fundamentalmente, la misma que la del lugar en una ficción con una diferencia esencial; en la autobiografía el sitio existe de verdad y es donde sucede lo que se nos narra. Esta 
evidencia me lleva a preguntarme si la Barcelona de la autobiografía es más real que la de la ficción. Es un cuestionamiento, esencial para este trabajo pero que dejo para más adelante. Sin embargo, me parece difícil creer que la Barcelona de Tusquets, el marco urbano de su autobiografía, sea más real que la Barcelona novelesco de Capmany o de Montserrat Roig. En realidad no se puede medir la veracidad de los lugares basándose en los géneros narrativos.

Barcelona es el lugar pero es también parte de la identidad de Tusquets en su autobiografía, donde trata de narrar no solo un tiempo sino también un espacio conforme a su narrativa. Con la autobiografía, el espacio, como por ejemplo, el barrio de la infancia de Tusquets, el Eixample, marca la organización de la narración y sus recuerdos topográficos casi establecen la estructura de su vida y de su narración. El espacio, aquí, es parte de la construcción del yo, de hecho toda relación a un sitio es, de cierta manera, un modo de autodefinición. No se puede negar una identificación obvia entre Barcelona y Tusquets lo que me lleva a pensar que se podría ver un vínculo casi metonímico entre la autora y su ciudad. Esto seguramente responde a la búsqueda identitaria propia a toda autobiografía, sin embargo, no me parece que Tusquets escriba para dar sentido a su existencia

Entonces ¿por qué escribir una autobiografía? La respuesta no es fácil y para mí se perfilan dos razones esenciales. La primera, puede ser el pacto autobiográfico, que la pone en relación directa con el lector, pero no cualquier relación, se trata de confianza y de intercambio relacional, al mismo tiempo el lector la percibe como escritora más bien que como mujer. Es decir que a través la rememoración de sus primeros recuerdos, de las historias y cuentos que le contaban y su educación, Tusquets no pretende en ningún caso 
ofrecer una confesión intima de ella misma, sino verificar como (y esto desde que es pequeña) la literatura ha estado siempre presente en su vida. Su segunda motivación, es su necesidad identitaria con la ciudad condal, su lugar de procedencia y su familia. Ella y Barcelona quedan reunidas indisolublemente y no solo por un momento, sino de generación en generación, suprimiéndose así toda alusión temporal.

Creo también, que la necesidad de pertenencia no solo es con su ciudad, sino también con su origen. El título de la obra Habiamos ganado la guerra, que es también la primera frase del libro, incluye a la autora explícitamente en el bando de los ganadores y marca la pertenencia a su familia. Sin embargo, en el último párrafo del libro, donde explica claramente que todos no habían perdido la guerra y que los que eran ganadores lo sabían bien y que no lo dejarían olvidarlo a los vencidos (276), Tusquets, se define así “[...] yo, hija de los vencedores [...] pertenecía al bando de los vencidos" (276). Es decir que, primero pone en relieve su filiación y después termina la frase con una declaración que contradice el título. Entonces, por qué no haber intitulado el libro Habían ganado la guerra, justamente porque la conjugación mantiene su pertenencia y el cambio de pronombre personal la hubiera excluido inequívocamente del lado de los ganadores, es decir, de su familia y de su entorno.

En este apartado, me enfocaré en la trilogía autobiográfica: Confesiones de una vieja dama indigna (2007), Habíamos ganado la guerra (2009) y Tiempos que fueron (2012) escrito, como he mencionado anteriormente, con su hermano el arquitecto Oscar Tusquets. ${ }^{13}$ Intentaré analizar la perspectiva y la visión de Esther Tusquets sobre su ciudad natal, Barcelona, siempre presente en sus memorias, y cómo a través del recuerdo recupera para el lector una Barcelona vista desde una perspectiva a la vez privilegiada y 
marginal. Al mismo tiempo estableceré un paralelismo entre la visión de Barcelona en la obra de Esther Tusquets y la de Montserrat Roig, concretamente en el uso que Roig hace de la memoria y cómo, para ella, el papel de la memoria y de la ciudad sirven en la creación de la identidad catalana y barcelonesa.

No cabe duda que la figura de Esther Tusquets goza de una importancia significativa en el mundo de la literatura por su éxito como editora de la editorial familiar Lumen, a través de la cual supo imponerse en el mundo exclusivamente masculino de la edición dominada por Carlos Barral (director de la famosa editorial Seix Barral), pero sobre todo, como autora de una densa y brillante producción literaria reconocida y premiada en el mundo de las letras españolas. Efectivamente, Tusquets fue unas de las voces más reconocidas de la literatura española contemporánea escrita por mujeres con una narrativa introspectiva escrita desde una perspectiva íntima no exenta de sexualidad que subvirtió, a finales de los años setenta, las normas de la sociedad patriarcal impuestas por cuarenta años de franquismo. Al mismo tiempo su obra nos ofrece una visión de la Barcelona del siglo XX y de la sociedad burguesa catalana a través de una mirada femenina, pero que, contrariamente a lo que cabría esperar por su catalanidad, escoge expresarse en lengua castellana, lo que plantea la cuestión de su nacionalidad literaria: ¿Es Esther Tusquets una autora catalana o española? La pregunta es parte de una polémica a la cual de ninguna manera pretendo poder aportar una repuesta clara y definitiva. Ante todo debería de poderse definir lo que significa ser un escritor catalán en la segunda mitad del siglo XX: ¿Haber nacido en Catalunya? ¿Vivir y escribir exclusivamente sobre Cataluña? ¿Ser catalán desde hace varias generaciones? ¿Sentir que Barcelona le pertenece porque de hecho es "su ciudad"? 
Naturalmente, podría pensarse que la Catalunya que les tocó vivir a la generación de escritores de postguerra era un entorno bilingüe y por esto optaron por escribir en castellano, pero entonces ¿por qué no escribieron a la vez en castellano y en catalán, que hubiera sido la opción lógica en un escritor bilingüe? Curiosamente, este es un tema poco aludido por la crítica literaria en sí, quizá porque toca aspectos identitarios que requieren planteamientos políticos, sin embargo no son pocos los autores nacidos en Catalunya que optan por escribir en castellano: Juan Marsé, Mercedes Salisachs, Rafael Argullol, Javier Cercas, Enrique Vila-Matas, Carlos Ruiz Zafón, Enrique de Hériz, Núria Amat, Eduardo Mendoza, Maruja Torres, Rosa Regás, Ana María Matute, Juan y Luis Goytisolo, Enrique Badosa, Francisco Ferrer Lerín, Félix de Azúa, por citar solamente a los más conocidos. Con todo, una cosa es evidente, estos autores forman parte de cualquier libro de historia de la literatura castellana contemporánea, pero no aparecen en los de literatura catalana y, de hacerlo, reciben un tratamiento aparte. Por lo tanto, no podemos aceptar sin más que Tusquets diga que no escribe en catalán porque en su casa, a partir de la victoria franquista, se habló el español, y que cómo nunca lo aprendió en la escuela, no lo dominaba bastante para poder escribirlo. Tampoco Terenci Moix aprendió el catalán en la escuela y, sin embargo, sus primeros textos son en catalán, lengua que, llegado un momento decidió abandonar por el castellano. Por supuesto, la situación personal de cada escritor es distinta y podríamos suponer que Tusquets es una escritora catalana que escribe en castellano por tener "circunstancias atenuantes." Es una cuestión que queda abierta y que, a pesar de que puede darse una explicación política por el carácter identitario de la lengua, lo cierto es que la respuesta es mucho más compleja y abarca otros aspectos. Así, Juan Marsé, al aceptar el Premio Cervantes 2008, declara que 
para él, la cuestión es escribir bien, pero para Marta Pesarrodona, como nos cuenta Tusquets en Confesiones de una vieja dama indigna, la cuestión era escribir bien en catalán, aunque para ello tuviera que someterse al duro aprendizaje de una lengua de la que solamente tenía un uso familiar y coloquial (14). Una opción que sorprendió a Tusquets por parecerle poco práctica, pues por un lado es necesario estudiar la lengua con la que se quiere escribir y, por otro, la difusión de esa lengua es muy inferior a la difusión del castellano (14). Es decir que para Tusquets, lo económico prima sobre cualquier ideología y no porque "mi catalán barcelonés no daba para nada" (Confesiones de una vieja dama indigna, 83) sino, porque sencillamente no le interesaba escribir en catalán porque no era catalanista

Cabe aquí, mencionar el entorno familiar de Tusquets porque pienso que hay una correlación directa entre la pertenencia social, pero sobre todo política de su familia, con su posición lingüística. Si para autoras como Maria Aurèlia Capmany y Montserrat Roig, el catalán fue la lengua amada preservada y transmitida de la casa por ser la que se oponía al castellano del" imperio español", en la casa de los Tusquets, esta noción y sentimiento nunca existió, antes bien, todo lo contrario, con la victoria franquista, se dejó de hablar el catalán en casa para hablar el castellano. Como lo explica Shaudin MelgarForraster, en su artículo "L'hora violeta y para no volver"dos lenguas, Barcelona y la mujer, después del franquismo la burguesía catalana, y particularmente la barcelonesa, se dividió lingüísticamente. La clase media siguió hablando el catalán y la clase alta se españolizó, simpatizó con el franquismo y adoptó una posición anti catalanista, su nacionalismo no fue el catalán sino el españolista. Es este exactamente el caso de la familia Tusquets, pues con la victoria del Ejército Nacional, la burguesía que 
consideraba que había ganado la guerra hablaba a los niños en castellano, lo que, simbólica y literalmente, representa la nueva generación franquista y española en el seno mismo de las familias catalanas. Como nos lo relata Tusquets, es cuando nace su hermano Oscar (1938) que en su casa se empieza a hablar castellano como medida de asegurar que el futuro del país era español sin dejar lugar a la lengua y la cultura catalana. Esta división lingüística que tiene lugar en Catalunya corresponde a dos ideologías diferentes, en las familias como la de Tusquets hablar el castellano se acompañó de un marcado españolismo anticatalanista, mientras que en la familia de Roig se siguió hablando catalán con muestra de una fuerte posición catalanista y antiespañolista.

Esto podría explicar, hasta cierto punto, las causas por las que algunos autores que se consideran catalanes escriben en español y sobre todo, por qué, como sostiene Juan Marsé en su discurso de entrega del premio Cervantes, no ven "nada de anormal en ser un catalán que escribe en castellano," aunque, por otro lado, también resulta evidente que el factor económico o de difusión es para muchos el elemento definitivo. Como ya he dicho, la pregunta es intrínsecamente polémica, y de hecho en el año 2007, la Feria del libro de Frankfort. Una de las más importantes del mundo, decidió tener como invitada a la cultura catalana. En un primer tiempo, las autoridades catalanas solo invitaron a participar a los autores que escribían en catalán. Esto provocó una "tormenta política y mediática" porque ofendió a los autores catalanes que escriben en castellano, pues estos sostenían que las dos lenguas son oficiales en Catalunya y, por consiguiente, tanto es parte de la cultura catalana, el autor que escribe en catalán como el que lo hace en castellano. Cuando lo cambiaron, era demasiado tarde, y autores reconocidos, como Eduardo Mendoza, Juan Marsé, Carlos Ruiz Zafón o Javier Cercas rehusaron la 
invitación. Podemos ver cuán candente es el problema del bilingüismo literario en Catalunya.

No obstante, como he sugerido anteriormente, ciertos críticos literarios no tienen dudas ante la cuestión. Por ejemplo, Anne Charlon en su libro La condició de la dona en la narrativa femenina catalana, solo considera y estudia a autoras catalanas que escriben en catalán y no menciona a Esther Tusquets, ni siquiera en el capítulo sobre las obras que tratan el lesbianismo. Para Alex Broch, Tusquets, tampoco pertenece a la literatura catalana sino a la española. Según Broch su narrativa sigue los pasos de la narrativa española encuadrándola dentro del "boom" literario y comercial perteneciente al grupo de escritores que eligieron escribir en castellano a pesar de ser un grupo catalanoparlante. Otra vez, de hecho, siempre topamos con la cuestión del bilingüismo, sujeto a polémica y en el centro mismo de la cuestión. $\mathrm{Si}$, como lo hemos visto, para ciertos autores catalanes escribir en castellano no es un problema porque consideran que Catalunya es un país bilingüe, para otros autores, como Maria Aurèlia Capmany y Montserrat Roig el argumentar el bilingüismo es un posicionamiento al servicio del estado español. En su artículo, Montserrat Roig: una Barcelona más, Christina Dupláa recopila una conversación-entrevista entre Capmany y Roig a cerca de la posición lingüística de estas autoras y del bilingüismo en Catalunya.

-“Hi ha companys de generació que van haber de dubtar entre una llengua i l'altra; la meva llengua literaria era la catalana, dice, señala Roig.

- Capmany le responde: "Estic completament d'accord. Avui he escrit un article que es titula: « Jo no sóc bilingüe ».

-La respuesta de Roig es; “Ja m'agrada que diguis això, perquè jo tampoc no 
m'en considero. Són els altres, els que ens fan bilingües. Sempre hi ha una diferencia de registres entre les llengües que dominem, o creiem dominar. I és una sort quan la teva llengüa materna és, alhora, la teva llengüa literària. (23)

Asumo que los autores que coinciden con la declaración de Marsé según la cual no hay "nada de anormal en ser un catalán que escribe en lengua castellana" (El País,2008) se adhieren a la misma convicción política de que Catalunya, quizás no es verdaderamente una nación, con su propia identidad y su propia lengua. Tusquets siempre sostuvo que no era catalanista, quizás esto sea la más sencilla y verdadera respuesta a la pregunta tan problemática del bilingüismo en Catalunya.

Ahora bien, quisiera aquí abrir un paréntesis para hacer hincapié en el inevitable paralelismo que se establece entre la situación lingüística y la femenina, ya que para muchas escritoras se trata de una misma reivindicación. En su libro, Des/cifrar la diferencia: narrativa femenina de la España contemporánea, Geraldine Nichols, nos da la definición exacta de "ginocrítica" y lo define como un "eufemismo de la crítica literaria" ya que la ginocrítica va más allá que la crítica literaria porque implica un cambio de situación para la mujer y pretende recuperar la palabra de los discursos silenciados, devolviendo la voz a las que impidieron hablar. Nichols también analiza la evolución del feminismo a través de sus teorías y nos ofrece un recorrido muy acertado de su historia, desarrollando un punto primordial para nuestro análisis al afirmar que "[t]oda crítica cultural es política (...)" (35). Y en el caso de la escritura femenina catalana lo es doblemente. El planteamiento que quiero hacer se elabora a partir del principio de analogía, es decir que estas teorías feministas, que de hecho denuncian el silencio de la mujer por la autoridad patriarcal, podrían aplicarse a las autoras catalanas 
que no pudieron escribir en catalán y fueron silenciadas. Es decir que la palabra recuperada por la genocrítica es en estos casos doblemente política, primero por ser palabra de mujer y segundo por serlo en catalán. Esta transferencia y a la vez amplificación de la genocrítica se aplica en su primer nivel a la escritura de Tusquets, ya que le devuelve discurso a la mujer e, incluso, le facilita un discurso sexual subversivo. Asimismo, es aplicable a los dos niveles en la narrativa de Capmany y Roig por escribir ellas en catalán. El lado político en el caso de Capmany y Roig es el que más resalta porque escribieron en catalán sabiendo lo que esto representaba a nivel político y económico, sobre todo para Capmany (limitación a un cierto público, dificultades de publicación y censura); al mismo tiempo su feminismo nunca pudo separarse de su nacionalismo ya que es parte de la misma opresión de ser y de vivir bajo una autoridad patriarcal. Se tiene que entender que el catalán no solo traduce una intencionalidad crítica sino también de ser. La reivindicación a la palabra aunque primordial en las etapas del feminismo no puede, en estas autoras catalanas, apartarse de ninguna manera de la lengua y, por lo tanto, de su identidad individual y nacional.

Antes de cerrar el capítulo sobre la genocrítica, me gustaría mencionar que Nichols dedica un capítulo a las teorías francesas, y de manera general lo que sobresale en su análisis es el papel que juega la palabra. El lenguaje es uno de los enfoques principales y toma un valor primordial por ser ante todo falocéntrico. Ahora bien, autoras como Capmany y Roig elijen remplazarlo por un discurso de mujeres, pero que de ninguna manera podría ser castellano, pues en sí mismo sería una contradicción, un oxímoron semántico. Por lo general las críticas francesas consideraban que para poder expresarse y liberarse, la mujer necesitaría otra lengua. En el caso de las escritoras 
catalanas, la otra lengua es simbólica y literalmente el catalán. Claro está que la sociedad catalana y su mundo literario era tan falocentrista como cualquier otro entorno cultural, pero en el espectro político cultural, escribir en catalán, era en sí subversivo y aún más cuando se trataba de una autora. El catalán se imponía pues como la otra lengua, como una herramienta y un vínculo para las libertades. Otro paralelo con la teoría francesa se apoya más precisamente en la teoría de Cixous, cuya crítica rechaza totalmente la representación binaria, es decir, privilegiado/inferior, masculino/ femenino. Para Cixous nos encontramos siempre ante una jerarquía o lo que es lo mismo con una desigualdad. Teniendo en mente el diálogo entre Capmany y Roig sobre el supuesto bilingüismo de Catalunya y la consideración y respeto que tienen por la lengua catalana, en el mundo de la edición, de la literatura y social de Tusquets, no cabe duda que, a la denuncia del sistema binario, se podría añadir el de la desigualdad castellano/catalán. En la disposición de estos dos elementos, el castellano sería el privilegiado y el catalán visto como la lengua inferior (sobre todo oral y no literaria). De la misma manera que Roig impone la palabra de las mujeres en la literatura y en las memorias de Barcelona, en su narrativa, también da la palabra y su lugar a la lengua catalana. En Digues que m'estimes, Roig consagra dos capítulos a su lengua y explica que tiene tres razones por escribir en catalán: "Primer perquè és la meva llengüa; segon perquè ès una llengüa literària; i tercer, escric en català perquè em dóna la gana" (28).

A pesar de la polémica situación de Esther Tusquets dentro del panorama literario catalán, me ha parecido esencial incluirla en mi estudio de la representación de Barcelona en la literatura femenina porque encarna un aspecto de la realidad cultural y social catalana y porque pocas escritoras han sabido como ella hacer de Barcelona el trasfondo 
de su obra. A través los libros de memoria que he seleccionado para este estudio, Tuquets nos ofrece una Barcelona percibida a través de las diferentes edades de un personaje, pero lo más interesante es que con ella vemos la vida cotidiana de los que habían ganado la guerra, de la burguesía franquista catalana que decidió españolizarse y españolizar Barcelona. Asimismo, nos encontramos con el testimonio de un momento fundamental en el desarrollo de la cultura catalana a través de una recreación de los ambientes intelectuales barceloneses durante los años de resistencia al franquismo. Por último, resulta interesante observar el papel que Barcelona juega en la obra de Tusquets y los paralelismos y diferencias que tiene ante la obra de Roig, una escritora de la misma generación y de una misma clase social parecido, pero que se decantó por diferentes opciones artísticas e ideológicas.

Creo que una de las cosas que se ha establecido, quizás mas implícitamente que explícitamente, es la dualidad entre las dos lenguas que se perciben como dos enemigas por representar dos ideologías opuestas en el contexto socio político de Catalunya. Sabemos que uno de las componentes más importantes de la identidad es la lengua y la importancia que implica el escribir en la lengua nativa y patria. A partir de esta toma de conciencia, la escritura adquiere otra dimensión y se convierte en una herramienta de transmisión. Como veremos en la narrativa de Roig, escribir en catalán es también recuperar la memoria de las silenciadas, y esta memoria no puede estar disociada de la identidad lingüística. Esta enunciación nos lleva inevitablemente al tema de la identidad y memoria o de la importancia de la memoria en la construcción de una identidad cultural al nivel individual o colectivo. 
Según Todorov hay una diferencia entre la recuperación del pasado y su uso, me parece que para Montserrat Roig, la razón por la cual recupera el pasado es el uso que hace de esa recuperación, es decir que es la meta principal porque en ella hay la prueba de la existencia del pasado de las mujeres de Barcelona, de sus espacios y de sus vidas olvidadas y relegadas al olvida por ser consideradas historias pequeñas y sin interés frente a la escala de la Historia. Pero, al mismo tiempo, el uso del pasado como elemento narrativo es esencial, pues consiste en transmitir este pasado por la escritura, pero una escritura catalana. Lo que se escribe no se olvida y una lengua es la expresión de una cultura, de una manera de pensar y de una cierta aprehensión del mundo; es exactamente lo que ilustra Roig cuando menciona al pueblo armenio en Dime que me quieres aunque sea mentira "[...] en 1915, en los campos de exterminio turcos las mujeres armenias dibujaban antes de morir las letras de su alfabeto para que sus hijos las recordaran para siempre" (43). Estas madres hacían literal y simbólicamente el gesto de la transmisión de una memoria que, a través de lo individual, se transformaba en nacional. Aquí el uso toma todavía otra dimensión, es transmitir el pasado por no olvidar quienes somos, es la transmisión de nuestros antepasados porque saber quienes eran nos permite saber quiénes somos y llegamos así a un reconocimiento no solo al nivel colectivo sino al personal.

De la misma manera que las madres armenias escribían el alfabeto que se iba transformando literalmente en signos de su identidad, en un intento desesperado de que sus hijos no perdieran su identidad étnica, cultural y nacional, Roig escribe en catalán porque hablando de la historia de mujeres catalanas que vivieron en Barcelona perpetúa el pasado que los organismos oficiales o incluso el patriarcado ha intentado silenciar. El 
catalán, aquí, es también una cultura que se ha transmitido desde generaciones y muchas veces a escondidas y con medio, de manera encubierta por las paredes del hogar. Ahora bien, para Roig la lengua se convierte en una herramienta y en un medio de imponer su nacionalidad, su identidad y su pertenencia a la nación catalana, al igual que la expresión del deseo de existir, como escritoras y mujeres catalanas.

En la obra de Maria Aurèlia Capmany, la memoria tiene una importancia primordial en la construcción y la recuperación del espacio urbano barcelonés. Por ejemplo, en su novela, Feliçment, yo soc una dona, la memoria juega un papel doblemente importante. Primero como memoria individual, la del personaje principal y después como memoria histórica de Barcelona, ya que Capmany se refiere, aunque a veces de manera implícita, a la memoria colectiva de Barcelona. Es este acercamiento a la ciudad de Barcelona que realiza Capmany lo que me llevó a reflexionar sobre el papel que tiene la memoria en la construcción del espacio urbano de Barcelona en las escritoras que hacen de esta ciudad el centro de sus novelas. Dentro del panorama de la literatura escrita por autoras barcelonesas, ya sea en catalán o castellano, Tusquets y Roig, son sin lugar a dudas las más significativas ya que Barcelona es el centro urbano por excelencia de sus novelas. Estas dos autoras, descendientes de la burguesía barcelonesa hacen que su ciudad sea la materia narrativa primaria de sus obras a partir de una relación de total interdependencia entre Barcelona y sus recuerdos, es decir que, la construcción literaria de Barcelona se cimienta en unos recuerdos los cuales, a su vez, no podrían existir sin Barcelona. Estas dos autoras, tienen mucho más en común que el solo hecho de pertenecer a la burguesía catalana barcelonesa. Las dos vivieron en el Eixample durante su niñez y tuvieron básicamente la misma educación burguesa que las llevó a realizar 
estudios universitarios en un momento en que los estudios universitarios todavía no eran algo generalizado en la educación de las mujeres. Otro punto común es que ambas autoras comparten la misma ideología socialista y que son mujeres totalmente independientes y atípicas dentro de una sociedad patriarcal. Sin embargo, sus narrativas sobre el espacio urbano barcelonés presentan por lo menos dos diferencias importantes para este trabajo, la primera, ya mencionada interiormente, es que Tusquets escribe en español mientras que Roig lo hace en catalán, la segunda es el hecho de que Tusquets recuerda Barcelona a partir de su niñez y escribe una autobiografía cuando Roig escribe novelas estableciendo un puente entre los recuerdos de su infancia y un pasado muy lejano e imaginario. Es decir que, trata de reconstruir Barcelona a partir de un intento de recuperación de la memoria aunque no tanto de su memoria como de lo que intenta que sea una memoria popular. Ahora bien, si bien es posible decir que Tusquets traiciona, de cierta manera, los recuerdos de su niñez, al pretender hacernos creer que es la niña la que recuerda, cuando en realidad son los recuerdos de una mujer adulta, lo hace sin perder la perspectiva de la clase social a la que siempre ha pertenecido, mientras que Roig pretende transmitir una memoria, la de clases populares, cuyas experiencias, por su calidad de burguesa, nunca experimentó. La imaginación juega por tanto un mayor papel en el proceso de recuperación de la memoria en Roig que en Tusquets y es por lo tanto que Roig acuda a la ficción. Así pues, mientras uno de los objetivos más importantes de la obra autobiográfica de Esther Tusquets, es la transmisión de la memoria personal, por el contrario, Montserrat Roig en Dime que me quieres aunque sea mentira, articula sus recuerdos personales en base a una memoria reconstruida como motor de ficción. Con 
todo, en ambos casos se persigue una reinterpretación del pasado dentro del marco urbano que les ofrece Barcelona.

Para analizar la dependencia espacio/ memoria en la trilogía autobiográfica de Tusquets y en Dime que me quieres aunque sea mentira de Montserrat Roig me he apoyado en la teoría de Pierre Nora del "lieu de mémoire" (lugar de memoria). En sus trabajos, Nora plantea la cuestión de las huellas en el recuerdo del pasado y construye la noción de "lieux de memoires" o lugares de memorias, a la vez de manera restrictiva, simbólica, funcional y material. Asimismo, frente a la problemática del olvido individual y colectivo, se pregunta ¿cómo explicar los lugares del olvido y la negación de la memoria? Por eso, Nora examina momentos particulares de la Historia y el fenómeno de su olvido del punto de vista colectivo e individual. Es justamente a partir de un planteamiento semejante al de Nora que Montserrat Roig habla de su ciudad y de sus lugares desaparecidos.

Al mismo tiempo, para analizar la correlación axiomática entre memoria/ciudad creo oportuno aplicar la noción bajtiniana de cronotopo (espacio/tiempo), pero con una pequeña modificación semántica, pues reemplazo la palabra espacio por ciudad y la palabra memoria por tiempo ya que casi todos los espacios en sus escritos podrían considerarse más bien como "paisajes" de memoria. Esta relación constituye los fundamentos de las descripciones de los espacios como lugares de memoria (o no lugares de memoria) y es esta relación también la que aporta muchos de los procesos retóricos o narrativos útiles a su edificación. 
A partir de esta perspectiva, según la cual los espacios en sus obras narrativas son espacios de memoria, debemos preguntarnos si se puede establecer una distinción entre espacios memoriales y espacios del pasado. De hecho, la cuestión del lazo entre Barcelona y memoria (espacio y tiempo o temporalidad), es compleja, sobre todo por los procesos de rememoración que funcionan dialécticamente entre realidades presentes y realidades pasadas. En este caso Barcelona y sus espacios juegan por lo menos dos papeles, uno activo, como un eslabón indispensable en el proceso de rememoración y otro, más pasivo, como un depositario de la memoria, ya que sus lugares son por naturaleza huellas de lo que ha sido. Por lo tanto, la representación del espacio puede jugar un papel en la recuperación de una memoria perdida o ignorada que, al mismo tiempo, es motor en la activación de la nostalgia.

Según el arquitecto italiano, Giorgio Cassani, la memoria para perdurar necesita ser concretizada, y claro está, en una ciudad esto se observa en la piedra. Las piedras tienen una forma de concretización del pasado, colectivo o individual, como los otros lugares de memoria, pero ¿qué hacer cuando la piedra desaparece y cuándo su olvido es voluntario? Es lo que plantea Roig tratando de recuperar estas piedras, esta memoria de Barcelona a través del recuerdo y de la imaginación.

En Dime que me quieres aunque sea mentira, es importante establecer desde un principio, que la recuperación de Barcelona en el cronotopo modificado memoria/ciudad se desarrolla en una doble temporalidad, primero con los dos representantes del tiempo: el tiempo linear, que la inscribe en su historia y que le supone un origen que busca perpetuamente: "La ciudad que yo busco quizá no ha existido nunca, o tal vez sí, y entonces es un desbarajuste de sonidos que no oímos, de fantasmas que no vemos" (162). 
Segundo, en una temporalidad cíclica, interpretada en Barcelona por ciclos de destrucción/construcción, esquema conectado, por una parte a una cultura del olvido y por otra parte, al hecho de que la ciudad es dinámica por esencia. Una ciudad, que para Roig, es ante todo un escenario memorial por lo que, de acuerdo con el concepto de Nora, toma el estatuto de "lieu de mémoire." Roig propone un método de aprehensión de la ciudad que hace de ella un producto de un espacio-tiempo donde el pasado sería dueño. Es decir, Barcelona es su pasado, no sólo en sus formas sino también en sus huellas materiales. La ciudad es la herencia de lo que su pasado ha producido y es imposible entender su sentido sin referirse a su pasado. Así pues Barcelona es una ciudad que tiene en su arquitectura la clara huella del tiempo en su espacio. En este sentido, Barcelona tiene dos ejes, el arqueológico, donde la ciudad presente cubre las ruinas de la ciudad pasada. Es decir Barcelona es una ciudad y varias ciudades a la vez, ya que está sometida a un proceso de pasado/invisible y presente/ visible y que sigue una lógica de ocultación que se une a la problemática del olvido (tema sumamente importante en la narrativa de Roig). Correlativamente, el segundo eje tiene un ángulo más bien deletéreo de los lugares de Barcelona, pues estos son también depositarios de la memoria como lugares sagrados, lugares donde descansan cosas muertas, casi como cementerios de la memoria: "Era una Barcelona que, en el siglo XIX, se moría lentamente, resoplando como un toro viejísimo mientras, no muy lejos, en la Ribera y en el Raval, las antiguas huertas se convertían en fábricas y sobre las casitas se levantabas pisos para meter, sin oxígeno ni higiene, a los nuevos obreros" (144). Esta Barcelona que se moría, ahogándose a sí misma y a su gente, es doblemente funesta porque destruyendo sus murallas construye pisos sepulcrales condenados al doble olvido de la muerte y de la 
memoria. Es a partir de este posicionamiento que para Roig la memoria en su narrativa, es más que nada, un deber. Su objetivo es recuperar el tiempo perdido casi en el sentido que da Paul Ricoeur ${ }^{16}$ al "deber de memoria". En su libro La mémoire, l'histoire, l'oubli, Ricoeur usa la expresión « deber de memoria » al hablar no solo de la memoria o del olvido propio del individuo o de ciertos grupos, sino, más que nada, del olvido voluntario y calculado de los sistemas políticos y gubernamentales. No obstante, aunque se pueda hablar de "deber de memoria" en Dime que me quieres aunque que sea mentira no se le puede dar la dimensión absoluta de Ricoeur, para quien el recuerdo se vuelve en un deber sobre todo en los acontecimientos histórico- político, dimensión que Roig logrará en su obra Els catalans als camps nazis, ${ }^{17}$ antes bien planteando la problemática del olvido y por consecuencia, la reinvención de la memoria perdida, pero no en un contexto directamente de eventos histórico/político. La pregunta que se perfila es ¿de qué memoria se trata y cuál es la memoria depositada en los espacios creados por Roig? Lo que le interesa a Roig es este pasado olvidado, amputado de la gente pequeña, de las mujeres y de los vencidos, de los que no tienen voz: "Las voces eran calladas, pero hablaban si se sabía escucharlas" (153). Unas voces que se nos muestran imbricadas en un espacio, el espacio de los olvidados. De este modo, Roig recupera las voces silenciadas y olvidadas mediante un proceso polifónico y la inserción de estas voces "recuperadas" de un mundo real, pero olvidado erige un monumento a la memoria de los vencidos, de los desaparecidos, de los que nunca hubieran dejado ninguna huella. De la misma manera, los espacios urbanos desaparecidos con las mujeres que vivían en ellos son exhumados gracias a su narrativa y casi se vuelven en lugares de memoria en el mundo real, en la esfera social. Así, el espacio se convierte en lugar de recogimiento e 
identificación. El espacio constituye pues un monumento, un lugar de memoria, es donde el lector puede revivir, sentir, lo que han percibido, sentido, esas personas dignas de memoria, gracias a la relación entre narrador y personajes. Imaginar y tomar consciencia de lo que vivieron estas mujeres es recordar al presente de sus existencias, una verdadera rememoración que hace existir de nuevo lo que había desaparecido. En Dime que me quieres aunque sea mentira, la doble destrucción de los personajes y de sus lugares es una de las temas centrales de los relatos. El texto de Roig intenta recrear una historia de Barcelona empezando en la Edad Media, una memoria de tipo histórico pero de la pequeña historia. Sin embargo, esta memoria de Barcelona está falsificada, transformada por el punto de vista distanciado e imaginado de la autora quien explica que se ha apoyado sobre la historiadora Teresa-Maria Vinyoles i Vidal, para poder recrear el pasado, y viajar en el tiempo tratando de imaginarlo, y de inventarse una memoria, "Con el excelente libro la historiadora Teresa-Maria Vinyoles i Vidal, La vida quotidiana a Barcelona vers 1400, he intentado viajar hacia atrás e imaginar cómo era esta ciudad por dentro" (Dime que me 129). A esta carencia histórica sobre la vida cotidiana de la gente pequeña se suma el pensamiento de Roig, según el cual la historia está escrita por los hombres y los vencederos, sin nunca dejar la palabra a los vencidos, entonces podría verse en este proceso, más que una simple cuestión de imaginación, el planteamiento de la veracidad de la historia, pues si son los ganadores quienes escriben sus historias, entonces, ¿qué confianza se puede tener en la historia de Barcelona escrita por ellos?

Es justamente por esto y porque el pasado de muchos lugares ha desaparecido sin dejar memoria que debemos distinguir entre las obras de recuperación de la memoria (Roig) y las obras autobiográficas (Tusquets), y entre los elementos, de lo imaginario 
personal y de lo colectivo que, simultáneamente, están puestos en el paisaje. En la narrativa de Roig, la memoria como lo imaginario, o quizás más lo imaginario que la memoria, son a la vez graneros, reservas y procesos creativos. Por lo tanto, ¿cuál es la memoria de Barcelona que reside en los espacios de ficción y qué memoria generan estos lugares? Roig describe lugares, como por ejemplo, la calle Ample, y monumentos, como Ramón Berenguer III, ${ }^{18}$ que manifiestan la memoria colectiva de los ciudadanos, asimismo menciona detalles múltiples y a veces propone una explicación histórica, casi simbólica de estos lugares. A su vez, la descripción del Eixample y de su construcción presenta la mentalidad de la burguesía catalana. Se puede decir que en la obra de Roig, el proceso de rememoración, se superpone casi exactamente a su pasado en su relación con la ciudad. Como he sugerido anteriormente, para Roig el proyecto social de recuperar la memoria colectiva se ve sometido al deseo, a la necesidad, de recuperar su propia infancia. El espacio de su infancia juega un papel primordial pues nos encontramos en una transformación del espacio en el tiempo. El Eixample su barrio, el patio, el limonero son símbolos de una Barcelona pasada, entendiendo con esto, que el patio de su niñez no se refiere a otro espacio, sino a otro tiempo, al pasado.

Por otro lado, en las crónicas de Tusquets, el lazo entre escritura y rememoración funciona según la modalidad proustiana, es decir, una autobiografía puesta en escena por una rememoración según el principio del recuerdo que ponen memorias personales y colectivas necesariamente superpuestas. Su memoria, es de hecho, su razón de escribir y de contar su niñez y su adolescencia intentando hacerlo desde la visión franquista de su familia. Escribe desde su memoria, pero de adulta y desde otra ideología política, sin embargo, observamos que el lazo entre ciudad y memoria es intrínseco al recuerdo. 
Tusquets presenta su narración como un simple recuerdo, y tiene la consideración de haber esperado muchos años para que la gente que aparece en su obra no sea reconocible o no se vea afectada por sus comentarios porque ya ha muerto. Algunos de sus recuerdos, parecen haber sido alterados por el olvido, ya que en el libro escrito con su hermano Tiempos que fueron, ambos autores no logran ponerse de acuerdo sobre lo que recuerdan, como es posible observar cuando hablan del pan negro en el cajón de la cocina. Ella afirma que en casa nunca se comió el pan negro de la posguerra y él afirma todo lo contrario. Este ejemplo apoya las conclusiones de Maurice Halbawachs ${ }^{19}$ y después de Paul Ricoeur, quienes en sus trabajos sobre la memoria han demostrado la relación entre los procesos de memoria individual y colectiva, de lo psíquico y de lo social, llegando a la conclusión que los recuerdos no dependen de la memoria individual y que nunca son una reproducción fiel del pasado. De hecho, la preocupación de Hallbawachs en su libro La Mémoire collective, era de distinguir claramente ente el "trabajo de sociólogo" del "trabajo de historiador". Trabajar sobre la memoria era, para él, escribir en contra de la historia de los historiadores y escribir una historia local y material, urbana, a la altura de los grupos sociales. Según él, la ambición de la memoria colectiva es de restituir una "historia viva", concreta y múltiple, en los intersticios de la historia. Con sus trabajos y reflexiones emerge verdaderamente la noción de una sociología de la memoria colectiva. Según Hallbawachs la memoria colectiva no solo se iguala a la suma de las memorias individuales, sino que se nutre y se forma mutualmente y el pasado se conserva a la vez en las memorias individuales y colectivas, históricas y sociales. En la memoria solo quedan "fragmentos" e "imágenes" y cada rememoración es una construcción, una recreación del pasado en función al presente. Para Paul Ricoeur la 
correlación lingüística y narrativa implica que toda memoria, aun la más individual y privada, sea constitutivamente de carácter social. O sea, la experiencia personal establece colectividad en el acto narrativo compartido. Para otros, como Walter Benjamin, solo podemos entender la memoria con respeto a experiencias vividas y siempre interpretadas en el presente; a su vez, el filósofo Gaston Bachelard subraya la importancia del espacio, natural o simbólico, en el entendimiento de los mecanismos complejos de los fenómenos memoriales.

La anécdota del pan negro demuestra pues la fragilidad de la memoria y explica como un recuerdo individual no se puede escapar de su marco colectivo. Es decir, plantea la problemática de saber si ¿es un recuerdo real o es parte de la memoria colectiva? De hecho, para Halbwachs, el principio más importante es el elemento de marco o cuadro social. La memoria individual no existe en sí, uno siempre recuerda a través y gracias a la memoria colectiva y el olvido es la desaparición de los marcos sociales. Regresando a la narrativa de Tusquets, es obvio que el recuerdo juega una parte esencial en el proceso de creación artística y que éste es el punto de vista del que parte su narración. Para ella, la memoria es un lugar privilegiado donde obtener el material privilegiado para sus novelas. Así pues, uno de los procesos retóricos más evidente en la trilogía de Tusquets es el elemento de recurrencia y repetición de sus recuerdos. Tanto cuando escribe sola en sus dos primeras autobiografías como luego cuando lo hace con su hermano Oscar, en Tiempos que fueron, la niñez y los recuerdos cohabitan y se superponen.

Con todo, como la memoria siempre posee una parte de subjetividad, nos encontramos ante una representación crítica de la realidad con lo que el acto de narrar se 
acerca más bien a una recuperación, reconstrucción crítica que a una tentativa de mostrar objetivamente lo que era. En Tusquets, el proceso de recuperación de la memoria se efectúa en el barrio de la niñez, y casi solamente en este barrio. Su infancia es el periodo historia "enterrada" cuando es niña y "desterrada" cuando escribe, es la posguerra inmediata que corresponde a la niñez y la adolescencia. Al igual que en el caso de Roig, la recuperación memorial es exclusivamente hecha por el proceso de la representación del mundo pasado: los lugares son centrales ya que tienen que explicar un entorno donde muchos elementos han desaparecidos tanto social como físicamente. Así es posible verlo en la descripción que del Liceo hace Tusquets pues este es un lugar de memoria personal, pero con un doble simbolismo social e individual. Este espacio construido, por y para la burguesía, es el lugar por excelencia de su pasado y se mantiene presente en todas las etapas de su vida. Como la voz narrativa nos indica: "En ningún otro lugar recupero tan integro mi pasado, ninguno está tan lleno de recuerdos (lo estaría el piso de la tía Blanca, o la casa oscura, o incluso el piso de Rosellón, pero hace mucho que han dejado de existir)" (200). Ahora bien, El Liceo es también un espacio emblemático de Barcelona a nivel social y político, pues representa la clase burguesa que lo construyó a mediados del siglo XIX, es como dice Tusquets un lugar casi sagrado "[...] tenía mucho de templo o de símbolo de una clase" (197). Este recuerdo personal del Liceo, que comienza cuando era niña y que vive primero pasivamente cuando su madre, cuando iba al Liceo, entraba en su cuarto vestida de gala para despedirse, corresponde al concepto de Halbwachs sobre la memoria familiar y las clases sociales, pues es un lugar que se transmite de generación en generación engendrando y conservando memoria. Para Maurice Hallbwachs una familia no es únicamente un grupo de individuales que tienen 
común sentimientos y lazos familiares. Cada familia reproduce "des règles et des coutumes qui ne dépendent pas de nous et qui existaient avant nous, qui fixent notre place" (145). Es decir que, cada individuo hereda un concepto general de la familia y su clase social que nos son inculcadas junto con nuestra educación. Sin esta continuidad que es la familia, los recuerdos desaparecerían. Así podemos observar como Tusquets enlaza ese espacio con sus antepasados a los que considera constructores del mismo: "Y cuando los bisabuelos de mis abuelos terminaron este templo..." (198).

La importancia del linaje en la memoria y en los espacios que ocupa se concretiza en la anécdota contada por Tusquets cuando la abuela va al banco que pertenecía a su esposo porque quiere recuperar el retrato al óleo de su difunto marido que presidía en el vestíbulo del banco (91). El caso es que la abuela nunca recuperó el retrato ni volvió a mencionar el episodio, lo que me lleva a pensar que con en esta "misión" (como lo llama ella), el objetivo de la anciana, para quien la pertenencia a un linaje prestigioso era de suma importancia, iba más allá que la simple recuperación del retrato. No creo que sea una decisión aleatoria, sino más bien, una estrategia para que Esther vea por si misma el banco que pertenecía a su abuelo y que hasta ahora no conocía. El banco pone de relieve la pertenencia a la clase social de la familia dentro del espacio urbano y establece una conexión espacial casi palpable, con el pasado glorioso de los Tusquets. Además, si la abuela escoge a su nieta y no a uno de sus hijos para acompañarla, es porque Esther, como adolescente, representa la continuidad del linaje. Con esta "expedición secreta" (91), la abuela quiere asegurarse que su nieta se sienta vinculada a sus antepasados y que la futura generación se proyecte dentro del marco burgués de los Tusquets. De hecho, en la descripción familiar de la familia Tusquets - Guillén, se deja ver la importancia y la 
presencia de los antepasados, lo que es casi siempre únicamente propio de la clase burguesa. La memoria familiar se construye a través de la grandeza del linaje o de la herencia, de los bienes y de los símbolos, legados por varias generaciones. Como en el caso de la pequeña Esther, la infancia es donde ocurre el arraigamiento biográfico en el cual los nombres o mejor dicho el renombre firman el capital genealógico y memorial, lo cual establece distintivamente la identidad familiar y la pertenencia a la clase social. En el estudio que Béatrix le Wita consagra a la cultura burguesa se subraya esta dimensión de la memoria: "Dans la bourgeoisie, la mémoire fonctionne comme un capital accumulé et transmis depuis des générations" (178).

Mientras la clase burguesa goza de la ventaja de guardar, a través de generaciones, no solo sus apellidos sino también sus lugares de memoria y su pasado, por lo contrario, los pobres se ven desprovistos de esta posibilidad, así como de poder escribir sobre sus vidas. Por consiguiente, Roig menciona que "La vida y la muerte de los obreros en este siglo de las "selfactinas" ${ }^{20}$ quedó incrustada en la fosa común de la literatura anónima y en los escritos que nos legaron los médicos preocupados" (148). Si por casualidad uno de ellos escribía a pesar de haber conocido la pobreza, ya no lo hacía desde esta misma pobreza, sino desde otra estatus cultural y económico, que lo alejaba aún más, de su condición primaria y que, por consecuencia resultaba en una mistificación del pasado. De la misma manera, en el paisaje urbanístico, nada se escribió en sus "piedras", los lugares que desaparecieron son las casas de madera y chapas onduladas de los obreros que antes constituían barrios enteros. En consecuencia, ¿qué territorios de origen pueden revindicar simbólicamente los obreros, las xinxes, los olvidados? ¿Qué espacio los recuerda? La memoria de los habitantes desaparece no solo 
porque la materialidad de los lugares desaparece, sino porque la destrucción de la gente y de sus casas sacrifica el pasado y condena sus vidas al olvido.

Es posible pues concluir que para el recuerdo, espacio y persona son dos elementos inseparables. Cabe pues plantearnos si es posible para las clases populares el forjarse una memoria. De hecho, según Wita, la memoria en las clases populares no se arraiga tan lejos en la historia y el pueblo no puede beneficiarse de la misma influencia del pasado. Esta representación se aplica a la memoria social y política tal como aparece en los trabajos de Maurice Halbwachs; quien, al principio del siglo XX, consideraba el presente como marco único de análisis de una clase obrera que todavía no había forjado ni unas tradiciones ni una memoria de clase propia. En este contexto, lo cotidiano que se vivía a través del trabajo y de las necesidades de la vida doméstica parecía ser el único horizonte posible de este medio obrero. Esta clase social emergente les separaba de su pasado y los dejaba impotentes frente a sus destinos y sobre todo sin consciencia de su historia colectiva, la cual estaba en este momento en su elaboración.

No cabe duda que los lugares de memoria en la narración están investidos en función de la intención del autor. Es necesario entender la diferencia entre los lugares de memoria histórica y los lugares de todos los días que, sin la representación rememorada nunca serán considerados como lugares de memoria colectiva. Este es el caso de las calles animadas de su infancia que nos describen Roig y Tusquets. Las representaciones de piedra que vemos en las narrativas son de la ciudad cotidiana, de los barrios y sobre todo del Eixample. Las descripciones de los pisos del Eixample donde vivía Tusquets representan las piedras donde se inscribió sus recuerdos de niñez y es también una zona emblemática de la clase burguesa: "La burguesía de mi ciudad se ha ido gradualmente 
hacia arriba, cada vez más lejos de la mar, desde la Barcelona vieja, situada por debajo de la plaza Cataluña, donde residían nuestros bisabuelos, hasta el Ensanche" (134). No cabe duda que el Liceo o el Eixample, más tarde la zona de Pedralbes, eran vistos como espacios propios a la burguesía, de hecho, hacen parte de estos mitos urbanos que cristalizan la memoria de la ciudad.

Como ya he mencionado, la escritura a partir de la infancia es también una de las analogías que une estas dos escritoras y la restitución de la memoria a través de los espacios pasa por procesos múltiples de rememoración personal. Sin embargo la memoria fundadora de cada una reside en la infancia y ¿no sería en este "lugar" que se han formado los lugares del presente? ¿No es en la colisión entre la historia personal y colectiva que se forja toda representación colectiva? Por eso, el proceso utilizado en las dos autoras es el de la rememoración personal puesta al servicio de la preservación de la memoria colectiva y por lo tanto el proceso de recuperación de la memoria no ficcional se efectúa en el barrio de la infancia. En los dos casos estamos frente a una evocación de las imágenes de Barcelona según el imaginario de una niña, que recupera un artista adulta y es a la escala del barrio que la ciudad se revela.

Roig y Tusquets hacen obra de memorialistas del lugar cuando reconstruyen la memoria del Eixample, donde crecieron. Se podría por lo tanto plantear si estos lugares de memoria son la memoria de un grupo y si este grupo se reconoce en este lugar. De hecho, resultaría interesante ver en que se parecen sus memorias del Eixample. Para Tusquets los pisos del Eixample son oscuros y el suyo no tenía balcón, lo que más recuerda es que su habitación tenía vistas sobre la Casa de les Punxes ${ }^{20}$ que le parecía a ella y a sus padres muy fea. Contrariamente en el caso de Roig, el Eixample es mucho 
más agradable y recuerda los balcones y las galerías, pero sobre todo, su patio interior con su limonero, lo que ella misma califica de paraíso perdido, "Solo con el tiempo descubrí qué había significado el aroma del limonero, descubrí que era mi paraíso perdido"( 52). Las sensaciones o emociones que el Eixample produjo en ambas autoras no son iguales, aunque los modos de vida y las reglas apegadas a la clase social son las mismas. Es en el recuerdo personal transformado en rememoración que los lugares del pasado surgen y la forma de recuerdos personales son, de hecho, elementos de la memoria colectiva. Las dos recuerdan la imposibilidad de salir a la calle y de jugar con los niños de las clases sociales más bajas. Aquí vemos que la memoria individual puede considerarse como un punto de vista sobre la memoria colectiva y que estas dos formas de recuerdos no se excluyen. Según Halbwachs, la participación al pensamiento colectivo permite a la memoria individual el llegar a recuerdos más alejados condicionando de este modo la posibilidad de remontarse en el pasado (31).

En las modalidades de escritura de recuperación de la memoria de las dos escritoras, la comparación entre lo que era y lo que es un mismo lugar, pone en primer plano los cambios, generalmente para desacreditar el presente. En su libro Confesiones de una vieja dama indigna, Tusquets nos ofrece fotos de su familia y sus amigos durante su juventud, y aplica la misma técnica cuando habla de los lugares, una técnica fotográfica que consiste en poner lado a lado dos fotos/lugares, una en negro y blanco y la otra en colores. En un lado los lugares como eran en el pasado y en el opuesto como son ahora. Sus descripciones transmiten la misma nostalgia del tiempo que pasa y del cambio de los lugares que casi nunca trae nada mejor. 
Otro aspecto común a Tusquets y Roig es la visión de su infancia como un país, a la manera de Saint -Exupéry para quien "chacun est du pays de son enfance” (34). En el caso de Tusquets el país de su infancia se convierte en el lugar de la memoria. La infancia es otro lugar espacio-temporal y no solamente un pasado. Los lugares del barrio de su niñez, conservados por su memoria, son huellas memoriales concretas de la infancia: son escritos de los recuerdos. El territorio de la infancia es un territorio seguro pero perdido, que solo puede ser reconquistado por la imaginación y la rememoración. Para Roig, la infancia es también un país pero sobre todo un "paraíso perdido" (49), donde no puede volver regresar físicamente.

Queda claro que el pasado sirve para aclarar o representar el presente en un objetivo argumentativo o histórico y que ninguna historia puede ser narrada fuera de una temporalidad. Además en todo proceso memorial, el pasado solo se manifiesta frente a un presente, y los espacios del pasado son el soporte de un discurso sobre los espacios presentes. Basándonos en todo lo que acabamos de ver, se puede decir que existen manifestaciones diferentes de memoria de la ciudad: los espacios como soporte de la rememoración personal y colectiva (el paisaje puente hacia el recuerdo) y los espacios depositarios de la memoria personal y colectiva, pero también pasado y presente funcionan de manera interactiva en estos mismos lugares. Por lo tanto el lazo entre ciudad y memoria es evidentemente central en el proceso de transmisión de la cultura, de la tradición y de la historia de la ciudad de Barcelona. No cabe duda, que la memoria es fundamental y es parte de la literatura. De hecho podemos afirmar que no hay literatura sin memoria, por esto, se puede decir que toda memoria es ficción por el tiempo que pasa y que altera los recuerdos, como en el ejemplo que nos da Tusquets del pan negro, 
totalmente inexistente en su memoria, pero muy presente en la de su hermano. Queda claro, que el pasado individual y vivido se transforma inevitablemente en ficción con el tiempo, y es justamente por eso que Roig, prefiere escribir una narrativa ficcional cuando trata de recordar el pasado de los otros, y mezcla así, recuerdos con ciudad imaginada y real en una serie de cuentos barceloneses.

Queda claro, que el pasado individual y vivido se transforma inevitablemente en ficción con el tiempo, y es justamente por eso que Roig, prefiere escribir una narrativa ficcional cuando trata de recordar el pasado de los otros, y mezcla así, recuerdos con ciudad imaginada y real en una serie de cuentos barceloneses.

Que sea ficción o autobiografía, toda ciudad, a pesar de una cierta inmutabilidad topográfica, queda también sometida a transformaciones radicales, o por lo menos a variaciones. De hecho, la ciudad posee una historia y sus mutaciones son la marca de una evolución perpetua. En la escritura del espacio urbano, la memoria, tiene una doble función, pues reconoce el arraigo de la historia en el espacio al mismo tiempo que rememora los recuerdos de los escritores vinculados a ese lugar. Se puede decir que Tusquets y Roig escogen la escritura como único medio para transcribir con gran precisión el pasado. Sin embargo, hay cierta diferencia en la percepción que tienen ambas autoras. Para Tusquets, es más que nada su pasado personal vivido en Barcelona lo que trata de recrear, mientras que para Roig es una recuperación del pasado de Barcelona a través los ojos de las mujeres que la precedieron.

En Habiamos ganado la guerra de Tusquets el encuentro con la ciudad es inmediato, pues se inicia con uno de los acontecimientos históricos más importante 
para la Catalunya del siglo XX. Me refiero a la entrada triunfante de las tropas franquistas en Barcelona (7), de este modo, la autora, desde un principio, se sitúa en el tiempo y en el espacio lo que es una condición sine qua non para el comienzo del relato. No cabe duda que el episodio marcó a Tusquets quien tenía en aquel entonces tres años. La autora intenta transcribirlo como lo vivió, es decir, a través de la alegría de sus padres, para los que el triunfo de Franco suponía también su victoria y el fin del encierro en el que habían vivido esos años: "Mi padre, que no había pisado la calle desde hacía casi dos años, me sostenía en alto para que viera desfilar a la tropa” (9).

Efectivamente, por miedo a las represalias, la familia tuvo que vivir escondida porque el padre que era médico, desertó del frente republicano (11) por dos razones, la primera porque no eran los de su bando y la segunda porque rehusó el trabajo que como médico se le había asignado, el "acercarse a las victimas tras los fusilamientos y, si todavía las detectaba con vida, darles el tiro de gracia” (11). Este comentario transmite cierta idea negativa de los republicanos, lo que se confirma a lo largo del libro, pues no son descritos demasiado positivamente, un rasgo que contrasta con las descripciones del tío Víctor, que era nazi, o del tío Juan, sacerdote antisemita y amigo de Franco, en las cuales se percibe siempre un tono de admiración.

El lugar donde se esconde la familia durante los últimos años de la Guerra es en un piso situado junto al monasterio de Pedralbes en el que la abuela vivía con sus dos hijas solteras, su hermana Tula y una criada ${ }^{20}$. Este espacio es principalmente representativo de dos elementos, de la estructura doméstica del mundo burgués, y del ambiente que reina en la casa como reflejo del de la calle. Como mujeres burguesas, la abuela, la madre y las tías no pueden valerse por sí mismas y no saben hacer otra cosa 
que gobernar una casa (12), por lo que, al no poder salir de casa, se ven condenadas a una inactividad y un aburrimiento absolutos. A pesar de la guerra y de las dificultades siguen teniendo a una criada, quien es la única mujer que trabaja en la casa. Estas distribuciones de los papeles corresponden también a espacios bien definidos dentro de la casa, por ejemplo, si el espacio común a toda la familia es el comedor, donde todos se reúnen, el espacio de la criada es la cocina, donde después de haber servido a la familia "la comida", ella regresaba a comer. El padre, sin lugar propio en esta casa, y más acostumbrado a salir y a trabajar, se siente como si viviera en una cárcel: “[ ...] donde mi padre no se atrevía a levantar la voz ni a asomar la cabeza a una ventana" (17). Todas esas condiciones de vida eran para todos un infierno, para todos, excepto para la niña Esther, para quien el piso de la abuela, representaba todo el contrario: el paraíso de su niñez, porque, como todos se aburrían tanto, ella era el único entretenimiento de la casa, y recibía toda la atención, especialmente la de su madre.

Después de la guerra, cuando la familia regresa al centro de Barcelona donde todos viven muy cerca los unos de los otros, los padres de Esther se mudan a su antiguo piso que ella denomina el "piso oscuro" ubicado en una esquina de la Rambla de Catalunya $^{22}$ con la calle Mallorca, a tres manzanas de la casa de la abuelita (como quería ella que la llamaran todos sus nietos), y otras tres en la dirección opuesta a la de su abuela materna y de su tío Víctor. Para llegar a la casa de su tía preferida, Blanca, solo tenía que cruzar dos calles y luego seguir por el Paseo de Gracia (21). Con el tiempo, este camino será el primer camino que Esther podrá recorrer sola, aunque bajo la vigilancia de su madre, quien desde el balcón principal, la miraba cruzar la calle. 
Este apartamiento, vivienda urbana por excelencia, es el piso donde nació y donde vivió de los tres a los diez años. Como todos los pisos del Eixample, "la casa oscura" tenía una galería: "una galería larga, con una hilera de ventanas, recorría de un extremo a otro la fachada posterior [...] tamizaban la luz que llegaba a las habitaciones, entre las que figuraban, en mi casa, el comedor y el cuarto de los niños" (30). El largo pasillo mal iluminado, "al que se abrían las puertas de todos los miedos", contribuye a la sensación de miedo, un miedo que nunca había sentido en el piso de Pedralbes y que experimenta ahora en el del Eixample. De hecho, esta casa se opone a la otra no solo por cuestiones arquitecturales, sino por razones sentimentales y afectivas, ya que es: "[l]a casa oscura, la casa de la soledad, la casa del abandono, la pérdida del paraíso" (31). Sin embargo, el piso era "un organismo vivo," puesto que, además de tener a dos criadas fijas que solo salían los domingos por la tarde, $[\ldots]$ había un trasiego continuo de personas que venían a repasar la colada, a planchar, a coser, a limpiar, a darnos clases a los niños"(31). Se puede decir que esta cita tiene doble función, no solo nos informa sobre la estructura doméstica de la burguesía sino que también, nos muestra que el sentimiento de soledad que sentía Esther es porque a partir de este momento, sus padres, pero sobre todo su madre, ya no tienen tiempo para ella y la dejaban en manos de las criadas. Podemos entonces, deducir que lo que siente Esther, no tienen casi nada que ver con el piso en sí, sino que sufre de un sentimiento de abandono por parte de su madre que nunca para en casa. (27)

En este piso, el espacio está típicamente dividido entre las actividades domésticas, la cocina, la galería donde Esther hacía su tarea, tomaba sus clases particulares o jugaba, la sala, las habitaciones etc... Pero lo que cabe destacar en la descripción que nos da 
Tusquets es el espacio que "pertenece" a las criadas y que metafóricamente es una ventana no solo hacia el exterior, sino hacia un mundo que Esther no conoce y que la asusta. Como dice la voz narrativa: "El cuarto de costura y de plancha era el punto de reunión, el núcleo de la zona de servicio" (31). La palabra zona apoya la separación de las dos clases sociales que son, de hecho, dos mundos. Uno de ellos que Esther solo conoce a través de los cuentos y las historias que se cuentan las criadas jóvenes casi todas procedentes de fuera de Catalunya, es también una zona transgresora ya que Esther oye historias, palabras, temas que nadie hubiera mencionado en el salón, pues "[e]l demonio, el pecado, el sexo, la muerte eran temas tabú para mis padres" (33). Me parece interesante añadir que este segmento, además de darnos una descripción de las condiciones de vida de las criadas, también muestra un cambio económico social; si lo comparamos con las criadas de principio de siglo, tal como lo vimos en La fabricanta, notamos que las criadas provenían de pueblos de Cataluña, sin embargo, después de la Guerra Civil, como nos los indica Tusquets, ya todas eran de afuera, lo que indica una emigración socioeconómico del resto del Estado español hacia Barcelona.

Regresando al piso, en el Eixample, el espacio típico de los hombres era su oficina instalada en las habitaciones que tenían un balcón (Roig, Dime que 135). En el caso del padre de Esther, su oficina es también su lugar de trabajo ya que era médico y tenía la consulta en casa. La sala de espera era la sala principal donde estaba el balcón, y donde de niña miraba la calle ya que el piso "[t]enía al igual que muchos pisos del Ensanche, tres balcones en la fachada principal, que daba a la Rambla Cataluña-un paseo arbolado que prefiero a todas las otras de mi ciudad-, y salir a ellos en primavera era como asomarse a un mar levemente encrespado de verdores tiernos" (27). En este piso, 
la visión de Esther es desde el balcón, espacio típico, casi icónico en la historia de la mujer barcelonesa. Será desde este balcón que verá construirse, “incrédula y emocionada" (28) meses tras meses el cine Alexandra justo en frente de su casa a pesar del hecho de que cerca había muchos otros. El cine aquí, al igual que los libros, era lo que abría la puerta a un mundo de fantasía y al mundo extranjero. A partir de esto, se puede decir que simbólicamente el balcón es una apertura al mundo de la imaginación y que es un espacio anunciador de otras posibilidades para la mujer. Si el balcón se puede interpretar como espacio premonitorio para el futuro de la mujer, para Tusquets, las galerías representan más bien la penumbra del pasado. Contrariamente a Roig, para Tusquets las galerías no tienen el mismo significado y no son fuentes de cuestionamiento sobre el pasado de la burguesía barcelonesa del siglo XIX. Tusquets no se detiene en las galerías, ni en el nivel literal ni en el figurativo y tampoco le interesan las historias que podrían esconder. Ya desde niña, su mirada es hacia afuera.

Cuando el número de pacientes esperando en la sala se hizo demasiado grande, la familia alquiló otro piso, “[e]l piso nuevo no tenía, como la casa oscura, un mar de hojas debajo de sus balcones (ni siquiera tenía balcones), ni tantos cines cerca, ni quedaba a una manzana de tía Blanca, pero seguía estando en pleno Ensanche a unos metros de la Diagonal (la disparatada emigración de la burguesía hacia la alta ciudad no había comenzado)[...] (135). Las informaciones sobre la dimensión del apartamento y su localización geográfica en el macroscosmos de la ciudad nos insiste en la pertenencia social de la familia, puesto que la sociedad barcelonesa está claramente marcada por el espacio urbano que ocupa. Las partes más altas de la ciudad están reservadas a los grupos dirigentes que, con los años, han ido mudándose cada vez más al norte, alejándose cada 
vez más de los barrios próximos al mar. Desde su habitación que era, la más gran de toda la casa, Tusquets explica que "[d]elante de mi ventana había un edificio extraño. Era una casa de pisos, con tiendas en la planta baja, pero recordaba por sus aspectos un castillo medieval, con muchas torres, que me parecía sacado de un libro para niños. Era la Casa de les Punxes ,y, al igual que la Pedrera o el Palacio de la Música, provocaba en mis padres un rechazo total" (136). ${ }^{23}$

Este piso, que, desde su ventana le da un campo de visión estrecho hacia fuera, le permite sin embargo, dar testimonio de un acontecimiento significativo de la época. Su casa estaba situada entre una comisaría y el piso del alcalde (137), y Tusquets cuenta que, como pasaba casi todo el día en la ventana, un día vio a la policía como detenía a un hombre que se debatía y que pedía ayuda a gritos diciendo que los policías lo iban a matar. Este episodio se convirtió en una pesadilla para la niña de 10 años que era Esther. Todo esto, la autora lo percibe desde su cuarto, desde el interior, a través de un campo de visión hacia el exterior muy restringido. Esta escena evoca un episodio de la novela de Roig, El temps de las cireres cuando la policía detiene a la protagonista por participar en una manifestación y el medio hace que se orine encima. (125). De cierta manera, la función represora y no protectora del ciudadano que ha ejercido tradicionalmente la policía en España, pero especialmente durante el Franquismo, justifica el miedo del detenido y permite al lector comprender la situación narrada. Lo que Tusquets ve desde la ventana, el desasosiego del hombre que grita, la protagonista de Roig lo vive de primera mano y confirma las dudas y aprensiones de Tusquets sobre el sistema que había ganado la Guerra y que supuestamente había devuelto el orden y la paz a la sociedad. Pienso que 
esta "interlectura" es legítima si aceptamos ver que en estos dos libros tan diferentes, es la ciudad literaria la que que permite que las dos historias se completen.

Esta ventana que devela a Esther una visión de la realidad acentúa el contraste con la vida privilegiada que llevaba con su familia: "En aquella Barcelona miserable, sucia, rota, chata, mal alumbrada, de una monotonía terrible, la Barcelona de las restricciones eléctricas, de las libretas de racionamiento, de más de media población aterrorizada y hambrienta, $[\ldots]$ los nuestros trataban de enriquecerse y de divertirse a toda costa"(24). Si nos enfocamos ahora, en el campo de visión, la edad aquí de la que mira no importa. Sin embargo, el texto ofrece al lector las cosas visibles desde el campo de visión de la autora. Ahora bien, desde este prisma visual la autora escoge sus propios encuadres, ya que como señala Roland Barthes: "Toute description littéraire est une vue. On dirait que l'énonciateur, avant de décrire, se poste à la fenêtre, non tellement pour bien voir, mais pour fonder ce qu'il voit par son cadre même: l'embrassure fait le spectacle" (61). Es decir que la ventana ofrece quizás un enfoque restrictivo, pero siempre procura una mirada, un campo de visión, que hace que sea él que crea el espectáculo a su dimensión. En la historia de Barcelona a través de la vida y mirada de las mujeres, Roig, explica que, ya en la Edad Media, la ventana era el medio que permitía a la mujer mirar el mundo exterior. La construcción del Eixample no fue una liberación para ella, porque el lugar que se les asigno, fue la galería interior de las cuadrículas de manzanas de edificios diseñados por el ingeniero Idelfons Cerdà. (Dime que, 135). Este lo subraya Christina Dupláa en un artículo consagrado a Roig y al espacio de las mujeres en Barcelona: "La mujer que mira a través de los cristales de El Ensanche sabe que los balcones han quedado relegados al servicio doméstico y que las habitaciones que los tienen son lugares 
donde sus maridos instalan el despacho. Las mujeres burguesas construyen su mundo en los espacios que dan a las galerías interiores. Allí están el comedor y la sala de estar" (Historia del avance, 44). Se puede decir que, si con los siglos las mujeres burguesas cambiaron su medio de mirada hacia el exterior, pasando de las ventanas, a los balcones y a las galerías, el simbolismo sigue siendo el mismo, el de la reclusión de la mujer en el ámbito doméstico.

Ahora bien, no se puede hablar de los pisos del Eixample sin mencionar los patios interiores. Me gustaría, ahora hablar del significado que tiene el patio y que lleva en este trabajo, el mismo simbolismo y función que el de los jardines en la literatura, tanto al nivel funcional como metafórico. En este análisis, el enfoque es más bien sobre un tipo de lugar, el patio/jardín, que sobre un lugar en particular. Pienso que este tipo de lugar, el "jardín burgués", es también un topos literario en el campo de la literatura barcelonesa, ya que aparece en varias novelas. ${ }^{24}$ Se puede decir que el topos literario toca el tema del jardín como espacio heterotópico, por ser un lugar que reenvía a otros lugares distintos de él mismo: el jardín es la expresión a la vez de la sociedad y de la intimidad de los que pueden beneficiarse de él. En este sentido es la expresión social y de cierta manera es la metonimia social en el mundo cerrado de lo íntimo: el jardín secreto. Esta intimidad, es lo que más se escapa del colectivo, protegiéndose del mundo exterior con altas paredes o verjas. Es un escenario que nos lleva inevitablemente a verlo como una metáfora de la consciencia, como intimidad irreductible. Este lugar, un encierro -abierto, se presenta a escalas variables según las narrativas pero, en el campo de lo imaginario, siempre atañe a la escala del microcosmo. Desde este punto de vista, el jardín o el patio, constituye un tipo de lugar particularmente interesante para entender el 
mundo, o más bien, una visión del mundo. Por ejemplo el jardín del Edén, reinterpretado por el jardín medieval cortés, o el jardín de Eloísa como jardín romántico, da un peso muy importante en la elaboración de este microcosmo. Partiendo de este topos, trataré brevemente de definir las especificidades que representa el topos del jardín burgués en las obras de Roig y Tusquets.

Los jardines o patios polarizan varios imaginarios que se interpretan y resaltan alternativamente o juntos en el espacio. Estos imaginarios son, por lo menos, de dos tipos; primero una dimensión estética que a su vez integra una dimensión sociopolítica histórica y segundo, una dimensión estrictamente personal afectiva y sentimental. De adulta, Roig sueña con el "patio interior de la casa familiar" y con el limonero, árbol simbólico por embellecer Barcelona hace algunos siglos, y que los forasteros tenían “[...] admiración por esta ciudad llena de arrayanes, naranjos y limoneros” (139). Al igual que este árbol, Roig está arraigada a su tierra, familia y pasado: "volví a mis raíces a través del patio" (22) y de la misma manera que hace siglos que Barcelona ya no se adorna de limoneros por las calles, el limonero de Roig, también ha desaparecido y solo existe en su memoria y como fuente de sueños en los cuales el aroma del limón la lleva al poema In memoriam de Gabriel Ferrater ${ }^{25}$ (Dime que, 22).

Al mismo tiempo el topos del jardín burgués es también la figura del jardín como lugar íntimo de felicidad, protegido de la violencia del mundo, "Rodeada de casas altas, bajas el indetectable pedazo de cielo azul, me sentía protegida" (Roig, Dime que 22). Estos jardines de tipo locus amoenus están sintetizados, sobre todo en la obra de Roig, y asocian el sonido y el color para caracterizar un ambiente, para ella, el limonero siempre será "el aroma a otoño, de la posguerra" (22), un mundo aislado, sin Franco, sin castigos, 
protegido, idealizado, casi un espacio urbano fuera de la ciudad y fuera de la realidad. Creo también que, sobre todo para Roig, este jardín es una imagen del útero materno, que la autora ubica en el seno de las manzanas del Eixample por ser el mundo de su infancia: un mundo abolido, soñado y añorado. Este estudio sobre el topos del jardín confirma en cierto modo, la importancia de la intertextualidad en el proceso de creación del mundo de ficción y el papel esencial que adquiere la metáfora en los textos de Roig. De hecho, el sistema de la metáfora explica en muchos aspectos el imaginario global de la ciudad en la obra de Roig. Me parece interesante ver el papel de los espacios en la construcción de los espacios textuales y ver la influencia y la importancia de la historia personal de la autora en las representaciones urbanas. Según Dupláa, en toda la producción literaria de Roig existe un lazo muy estrecho entre su biografía, su memoria personal y colectiva (142). En efecto, Roig, como Natàlia Miralpeix , la protagonista de El temps de les cireres, se da cuento con su regreso a Barcelona después de doce años de ausencia, que el patio y su infancia ya pertenecen al pasado de su vida.

En el sentido sociopolítico histórico, los cambios que sufrieron los patios, hacen de ellos solo el reflejo de una generación y de la desintegración de cierta clase social. Lo vemos en la descripción estética de los patios descritos por Roig, que sirven para construir un discurso sociopolítico de la burguesía de los años de la posguerra del barrio en decadencia en comparación a lo que esta era a principio del siglo XX, cuando estos apartamentos eran signo de riqueza. Más allá del mensaje de añoranza que evoca el limonero, el encerramiento del patio indica el instinto de auto defensa y de repliegue de la burguesía catalana en sí misma Es una configuración metafórica de la decadencia de la burguesía catalana y de los efectos de la Guerra Civil. 
Si en la obra de Tusquets, Barcelona se convierte en el espacio literario autobiográfico, en la obra de Roig, como lo afirma Duplàa, su narrativa reflexiona sobre la transformación de la ciudad con respeto a sus barrios, clases sociales y la diferencia entre las generaciones de mujeres. En ambas autoras, la percepción de la ciudad a través la mirada femenina es importante, pero en especial en Roig es fundamental, resultando este aspecto especialmente evidente en el uso que la autora hace los olores, pues encontramos en sus libros lo que Charlon afirma que es posible encontrar en la narrativa femenina catalana, la cual se puede reagrupar en tres categorías dependiendo del uso que se hace de los olores: los olores del aire o de la natura, generalmente asociadas a la sensación física de felicidad; olores de los mercados; olores de cocina y comer (208). Para Roig, la Barcelona de su infancia se identifica con el olor del limonero, pero también del aspecto de la naturaleza más característico de Barcelona, el mar: "[m]ar y arena, olor salobre, intuido desde el patio interior" (Dime que, 52).

En las manzanas del Eixample, los olores también marcan la estratificación de la microsociedad de sus edificios: "El cuchitril de las portera estaba abajo y desprendía el indefectible olor de los pobres del Ensanche: col hervida y pescado frito" (Dime que, 51). Así que, según Roig, la pobreza también puede reconocerse por su olor. Pero, es de notar, que esta asociación de olores y clase social, viene de la portería, lo que es literal y metafóricamente de abajo y así es, como Roig entendió, ya de niña, que el espacio definía a las personas (51). La microsociedad constituida por los habitantes del edificio es entonces ella también, a la manera de la ciudad, jerarquizada y reconocible desde el punto de vista de la estructura espacial. 
Con todo, no cabe duda, que los recuerdos olfativos son un recurso precioso en el proceso de rememoración. Roig, a la edad adulta, para recordar el olor de las calles del barrio de Sant Pere (por donde pasaba con su madre para ir al mercado de Santa Caterina) piensa “[...] en el olor que despide la piedra rancia cuando apenas la calienta el sol" (Dime que 144). Esta cita establece que la piedra, además de representar el pasado por ser el elemento básico de construcción de la ciudad, también tiene una cualidad más volátil, pero que le da la misma función, la de provocar los recuerdos, pues porosidad absorbe olores y pasado.

En los recuerdos de Tusquets, uno de los espacios urbanos con un peso significativo son las escuelas, donde pasará su infancia y donde aprenderá a ser lo que es. Esther siempre asistió a escuelas extranjerolas, y el espacio escolar fue su primer espacio de relaciones sociales. El Colegio Alemán de la calle Moià, que era mixto y no era religioso sino era laico, era un gran edificio en cuyos salones había siempre una foto de Hitler. Terminada la Segunda Guerra Mundial, la escuela cerró y tuvieron que buscar otra escuela. Después de pasar por varias de ellas, Tusquets terminó su bachillerato en el Nuevo Colegio San Alberto Magno, también alemán y con una gran mayoría de alumnos extranjeros. Esta escuela se ubicaba en una torre de Vallcarca. Será en este colegio que encontrará su primer "amor", el señor Jiménez, profesor de literatura. Este profesor le descubrirá el Barrio Gótico, que Tusquets desconocía. Había viajado por Francia e Italia, pero como tantas personas de la clase alta, vivía de espaldas a ciertas áreas de Barcelona que podían con su crudeza mostrarle la realidad de la ciudad y de la sociedad en que habitaba. 
En la construcción del espacio, ambas autoras dan gran importancia a la casa. Es el lazo por excelencia en el macrocosmos de la ciudad. En los dos casos la casa tiene un papel diferente pero esencial. El espacio urbano que representa la casa es siempre representativo de la clase social y el barrio, lo que es inmediatamente a fuera de la casa es igualmente importante, sobre todo para niñas de la burguesía que no podían aventurarse solas por la ciudad, pero que tenían permitido, como Esther, cruzar la calle o ir a la pequeña librería Trirreme muy cerca de casa (138). Este espacio libresco se convirtió para ella en un lugar especial donde podía pasar horas hablando con el dueño y donde su peculiar personalidad de niña fascinada por los libros pudo desarrollarse. En este mismo barrio, "en la esquina de Rosellón con Diagonal había, y hay, un bar, el Bauma, que fue durante años punto de encuentro con mis amigos o mis novios [...] (138). El bar es un espacio urbano ineludible en la literatura de Barcelona del siglo XX y XXI y si en la novela de Feliçment, jo sóc una dona de Maria Aurèlia Capmany, la mujeres que iban al bar eran mal vistas, ya es algo que Tusquets y Roig casi no conocieron de adultas. El bar se convierte en un lugar público sobre todo para la juventud "intelectual". El bar, como casi todos los espacios de la ciudad, tiene su propia función y particularidades. Es parte del espacio urbano barcelonés y permite el encuentro entre los individuos. Otros lugares urbanos, como las plazas, los grandes bulevares, son espacios donde la gente también se encuentra y se relaciona. Entendida así, esta dimensión de la ciudad establece un compromiso entre espacio y vidas individuales permitiendo así su unidad al garantizar la reunión de sus habitantes.

De la misma manera, sentarse en un bar, supone una apropiación de espacio urbano. El bar, como simple componente de una ciudad, es a primera vista impersonal y 
puede estar ocupado por cualquiera, pero, el hecho de siempre sentarse en el mismo bar, da una impresión de familiaridad, o un espacio de proximidad, del cliente con el lugar. Escogiendo unos lugares precisos y habituales, como por ejemplo, el café Bauma, o ya más grande, la cafetería del Paseo de Gracias, Tusquets se los apropia, determinando y marcando su posición en el seno del espacio urbano. De este modo, pertenece a Barcelona en el sentido que posee su "sitio" en ella. A partir de esto, se puede decir que la relación de Tusquets con Barcelona es, sobre todo, una relación íntima, lo que quiere decir que si la relación entre el individuo y el espacio se entiende como una apropiación, entonces, se instaura un pacto entre la ciudad y su ciudadano. Aquí, la autora teje un lazo con su ciudad y una complementariedad entre las dos entidades se establece. De hecho, el principio de apropiación de una ciudad tiene similitudes con la noción de vivencia que como afirma Bachelard "[..] tout espace vraiment habité porte l'essence de la notion de maison"(24). Quizás sea por esto, que cuando uno se siente verdaderamente pertenecer a una ciudad dice que se siente en casa. La ciudad tiene también la capacidad de acoger y aceptar múltiples existencias adentro del mismo decorado. Asimismo constituye un entorno apto para hospedar una multitud de gente sin dejar de ser la misma única ciudad.

Uno de los rasgos comunes a la burguesía catalana era tener abono al Liceo. De hecho, para ellos, no cabía duda, el Liceo era su propiedad, construido y frecuentado por ellos. Como ya hemos mencionado, el Liceo es uno de los lugares más emblemáticos de Barcelona. En casi todas las novelas se menciona, La Fabricanta, El carrer de la camèlias, El temps de les cireres, etc. Es un establecimiento sumamente importante en la historia urbana y político social de Barcelona y, tras su incendio, fue reconstruido, como dice Tusquets, como una copia casi perfecta de lo que era (200). Sin embargo, los 
espectáculos que se representaban al Liceo, iban más allá que las obras artísticas. Quiero decir, que la vida urbana también ofrecía un espectáculo. La entrada del Liceo en la Rambla, era un espectáculo garantizado por la burguesía que entraba en el teatro: “[...] entrábamos en el teatro flanqueados por un nutrido grupo de gente que se apostaba allí para vernos pasar: la llegada de la burguesía a su templo convertida en espectáculo popular" (204).

En la novela de Rodoreda, El carrer de las camèlies es exactamente lo que se describe, la misma escena, pero desde la mirada popular. Se explica como la clase baja miraba este desfile burgués brillante de riqueza e indiferencia. De hecho, esta cabalgata triunfal es tan emblemática del éxito social que la meta de la protagonista de Rodoreda no es otra que poder llegar un día a cruzar la calle, esta frontera de bitume que separa las dos clases sociales. Esta analogía entre teatro y espacio urbano, presta a la ciudad un doble significado: es a la vez decorado que apoya la acción y la acción en sí. La actividad urbana permite la especificidad de las actividades de sus habitantes, al igual que una ciudad desierta parecería ser amputada de una parte de su significado. Así pues, cada ciudadano tiene que definirse en su propio rol y hasta en su propia existencia. Pero sobre todo, tiene que entender que la población define la ciudad tanto como la estructura geográfica.

No obstante, al igual que en un juego de espejos, el Liceo es generador de espectáculos, uno afuera, uno en el escenario (la obra artística) y la tercera "la función autentica, $[\ldots]$ tiene lugar siempre en los pasillos, en el Salón de los Espejos, en el Círculo o en los mismos antepalcos, porque una cosa es que uno financie determinados actos culturales y otra cosa sería muy distinta-acaso incluso peligroso- que se tomara la 
cultura demasiado en serio" (199). Con estas palabras, Tusquets nos da una crítica severa de la clase burguesa catalana y al mismo tiempo, apoya una vez más que la pertenencia social está por arriba, o por lo menos, define tu espacio social.

En esos días, la clase burguesa podía pavonearse con todas sus joyas cuando iba al Liceo: "No existía peligro de robo y la señoras andaban envueltas en pieles y cubiertas de joyas" (Habíamos, 204). De hecho, no hay en el relato de Tusquets el sentimiento de medio debido a la criminalidad cuando habla de la Barcelona de su niñez, casi todo lo contrario. Ahora bien, pienso que este ambiente de seguridad se opone a una situación que Tusquets describe en Confesiones de una vieja dama indigna. Se trata de una anécdota sobre uno de sus primeros viaje a Nueva York con su amiga Vida. Cuando recuerda este viaje lo primero que le viene en mente es la imagen de "jóvenes negros, altos, hermosos, soberbios, terribles, recorriendo sus calles, tomando sus calles, haciendo suya su ciudad, precedidos por parejas de perros doberman, $[\ldots]$ terribles como ellos”(195). Esta enumeración de adjetivos, altos, soberbios, terribles, me lleva automáticamente a pensar en una descripción de Nueva York escrita por Louis Ferdinand Céline ${ }^{25}$ cuando llega por primera vez a Nueva York por barco.

Figurez-vous qu'elle était debout leur ville, absolument droite. New York c'est une ville debout. On en avait déjà vu nous des villes bien sûr, et des belles encore, et des ports et des fameux mêmes. Mais chez nous, n'est-ce pas, elles sont couchées les villes, au bord de la mer ou sur les fleuves, elles s'allongent sur le paysage, elles attendent le voyageur, tandis que celle-là 
l'Américaine, elle ne se pâmait pas, non, elle se tenait bien raide, là, pas baisante du tout, raide à faire peur. $(152)^{26}$

Esta descripción muestra Nueva York como una ciudad de pie, erecta, completamente opuesta a una ciudad acostada. Me parece justo decir que Céline da a Nueva York atributos masculinos, con connotaciones sexuales evidentes, es rígido, tieso lo que apoya la insinuación latente de una erección, además el "raide à faire peur" expresa una rigidez peligrosa y agresiva. Este lado imponente, fuerte, y amenazador se opone a la imagen de las ciudades acostadas y esperando a los viajeros, como sería lógico en cualquier puerto, ciudades con atributos femeninos casi lascivos y que corresponden a una ciudad como Barcelona. Esta percepción que da Céline de Nueva York, me a comparar estas dos ciudades no por ser dos puertos, sino por el contraste de visión y de género que estas diferencias imponen. Si Nueva York está percibida bajo el género masculino, Barcelona se concibe más bien como una ciudad femenina. De hecho, Roig explica que Bernat Metge (un escritor catalán del siglo XIV) escribió en su obra más famosa Lo somni, que casi todas la provincias y hasta la ciudad de Barcelona tenían nombres femeninos. Por consecuencia, a partir de este momento, Barcelona ha estado siempre comparada a una mujer. "Mientras el estado representaba el padre, la ciudad era como una madre...” (130). Según Roig, no siempre fue madre, ya que según el momento pasó de ramera a vieja dama, o de un poco santa a un poco bruja, pero, siempre mujer (131).

Este concepto de Barcelona como mujer me hace preguntarme si en las obras de estas dos autoras se puede hablar de una personificación de Barcelona. Se puede afirmar 
que en la obra de Roig, la personificación de la ciudad es obvia ya que las metáforas en este sentido abundan, por ejemplo: "Las calles y las plazas son la epidermis de las ciudades. Las casas, sus órganos inferiores; en ocasiones el corazón, otras las entrañas" (Dime que 125). Con varias representaciones a características orgánicas, la ciudad se presenta como una persona y hasta puede vestirse como un ser humano. En Dime que me quieres, Roig explica que ya en los siglos XVI y XVII los forasteros le prestaban característica propias de las mujeres de la época: "Barcelona se sabía tan hermosa que prefería ser mirada a mirar hacia fuera" (139) la referencia estética que se da a la ciudad, le confiere una identidad simbólica y se habla de ella como de una mujer bella y consciente de su belleza, pero es también una pasividad que puede resultar peligrosa. En la obra de Tusquets, a pesar de la cita en la cual califica Barcelona de "sucia, rota, chata, malhumorada" (23), no se puede verdaderamente hablar de una personificación de la ciudad condal . Es su ciudad y una ciudad que quiere, pero se percibe una distancia que no permite la intimidad de la personificación. Me parece que la relación con su ciudad es más pragmática que la de Roig y da la impresión de ser elitista en sus recorridos y descripciones urbanas. Por ejemplo, el espacio del mundo obrero es completamente inexistente y Tusquets solo lo percibe a través las historias de las criadas, por lo que se queda en el espacio que les presta la casa, la cocina o la sala donde planchan y cosen. No solo se les otorga un lugar diferente, sino también sentimientos distintos. Las criadas tampoco tienen una imagen positiva ya que son las que roban, mienten, pegan y maltratan a su hermano y, para colmo, matan a su primer perro. Según la voz narrativa, lo hacen por venganza, por haber perdido la guerra y por ser pobres. Podemos deducir que Tusquets establece implícitamente una correlación directa entre ser pobre y ser de 
izquierdas y ser rico y franquista. Todo esto muestra la brecha enorme entre los dos mundos, tanto a nivel espacial como a nivel humano.

Se puede decir que, en Habíamos ganado la guerra, Tusquets descubre Barcelona por etapas, y desde este momento, la percepción del espacio urbano se hace bajo el signo del descubrimiento. Pero, al ser del orden de lo cotidiano, el lector urbano contemporáneo puede poner imágenes sobre el texto, creándose un entorno mental. Una referencia común se instala, desde este momento entre Tusquets y el lector. El texto transmite al lector las cosas visibles de la ciudad, pero estando en la imposibilidad de ponerlo todo de un golpe, la narrativa urbana propone, en términos de descripción, presentar el espacio urbano siguiéndole de la vista. La lectura permitiría, entonces, de construir el entorno del texto, y el lector (para llenar la metáfora) sería como un "flâneur" quien, conforme a su marcha, abre su perspectiva para descubrir nuevos paisajes y la ciudad que la autora le presente al ritmo de la lectura. Sin embargo, la escritura de lo percibido es siempre problemática, ya que debe transformar el espacio urbano en una secuencia lingüística. Como afirma Paul Ricoeur en Temps et Récit, "le monde que le récit re-figure est un monde temporel" (110). Así pues, la descripción urbana trata de seguir el desarrollo cronológico de la escritura y su originalidad consiste en transformar una superficie espacial en un cuadro temporal.

No obstante, la presentación de la ciudad siempre se hace, como ya lo hemos visto, desde un punto de vista especifico. De este modo, en la obra de las autoras, que el lugar sea real o imaginario, un paisaje o un detalle es un lugar que siempre nace de una mirada de mujer y de una perspectiva o punto de visión propio de la mujer: se trata de 
una visión quizás menos completas que las masculinas, pero igualmente reveladoras de la ciudad, puesto que delimitan tanto los aspectos interiores como los exteriores. El funcionamiento urbano se lee a través de este doble fenómeno que corresponde a la dialéctica del afuera y del adentro. Es decir, que todo retrato de la ciudad solo se puede hacer a partir de una focalización particular. Tusquets como Roig, no quieren abrazar el espacio urbano en su totalidad y se inician gradualmente en los secretos de la ciudad. Es decir, que el medio urbano corresponde a un espacio iniciático del cual Tusquets y Roig saldrán crecidas. Barcelona, es por lo tanto, el lugar determinante para sus identidades, por lo que la ciudad constituye el espacio en el cual ambas escritoras se han constituido como personas. La noción de formación, tomado en su primer sentido, insiste en la huella del lugar sobre la persona. Lógicamente, formar una persona es darle forma, decir que una ciudad es formadora, es definirla como un molde en el cual el personaje urbano encuentra su forma. La ciudad corresponde a un entorno dentro del cual sus identidades se construyen y por esto hablan de Barcelona como del espacio determinante para su identidad.

Uno de los elementos que se puede prestar a Barcelona y que resalta en la narrativa de Tusquets es el ritmo de la ciudad, porque ritmo y espacio no pueden disociarse. La estructura de la ciudad también puede leerse desde un punto de vista temporal o dicho de otra manera, la ciudad posee un ritmo, una cadencia, que le es propia y que es la marca de su funcionamiento. El movimiento urbano, si por un lado permite estructurar la ciudad, también se ve dotado de una cierta regularidad. El transporte público, permite al narrador volverse en espectador y variar la orientación de su mirada. Así, cuando, los hermanos tomaban el tranvía con la tía Sara, en lugar de tomar un taxi y 
de ir a las Granjas Catalanas, Esther lo disfrutaba mucho más porque daban muchas vueltas y veía un nuevo mundo: “Oscar y yo éramos niños y tía Sara nos ocupaba la tarde dando vueltas en tranvía” (134). Así, el tranvía permite a la autora de ver la ciudad no solo a altura humana, sino también desde otra perspectiva. Ante todo, los tranvías funcionan como un metrónomo que asegura la regularidad de un tempo y que rechinan durante las vacaciones, cuando el Eixample está vacío. Frente al tranvía, el taxi, es lo que utilizaba la burguesía para su transporte en los espacios urbanos. Otro ritmo propio a la ciudad eran las vacaciones de verano que los burgueses siempre pasaban fuera de Barcelona. Esther y su hermano, siempre iban a la Costa Brava y, al contrario de las otras familias, se quedaban allí solos todo el verano con las criadas. La burguesía se iba de vacaciones, pero la gente de poco medios se quedaba a Barcelona (75). Vemos que las vacaciones tienen su propio ritmo y que la burguesía abandona la ciudad llevándose con ellos los ruidos. Las pocas veces que Tusquets vuelve a Barcelona durante sus vacaciones encuentra: "[...] a una ciudad desconocida, fantasmal, absolutamente desierta; seguramente los barrios populares eran un hervidero de gente, en el Ensanche, la mayor parte de las tiendas y locales estaban cerrados, y por allí no transitaba un alma no se oía otro ruido que el rechinar de los tranvías" (79).

Si ambas autoras son vistas como hijas de Barcelona, es posible afirmar que la ciudad actúa a manera de madre. Como he sugerido anteriormente, una madre en el sentido de un espacio uterino que forma hasta la madurez. El carácter matricial de Barcelona da vida a una relación de fusión entre la ciudad y las autoras. Esta relación entretenida con la ciudad corrobora la presencia de una conformación, en el primer 
sentido de la palabra, de las autoras al espacio urbano barcelonés. De hecho, la fusión ente ciudad y mujeres puede leerse a través de huellas dejadas en el espacio urbano.

Se puede concluir que, al poner su relato en el centro del espacio urbano, estas autoras concretizan mediante la palabra la ciudad. Casi puede decirse que efectúan una topografía, es decir, crean un espacio literario. Sin embargo, la escritura de lo percibido es siempre problemática ya que debe transformar la extensión espacial de lo visible para convertirla en une secuencia lingüística en un cuadro temporal. Lejos de darnos una descripción sobresaliente del paisaje urbano, las autoras abren una brecha en la ciudad y la observan desde el interior. Son los acontecimientos del interior que están puestos en valor y esto nos ayuda para presentar la vida de los habitantes de la ciudad.

Montserrat Roig escoge Barcelona como escenario para todas sus novelas. La Silvia de Ramona, adéu, la Natàlia Del temps de la cireres, Judit y Agnès de L'hora violeta y Patricia de L'òpera quotidiana, todas ellas son, como Roig, hijas del Eixample, donde vivieron encerradas, pero con una apertura al mundo más grande que sus abuelas y bisabuelas. Sin embargo, de este barrio que simbolizó la modernidad de Barcelona en la mitad del siglo XIX, Roig no describe su decadencia, decadencia que corresponde con los años del franquismo. En su obra, hay una introspección absoluta entre ella y la ciudad. Busca en el pasado de la ciudad, en el espacio urbano no solo las pruebas de una existencia femenina, sino también sus propias raíces, por ser catalana, mujer e hija de Barcelona. Busca y denuncia al mismo tiempo, y en Dime que me quieres aunque sea mentira, sintetiza y explica su voluntad para recrear la historia de Barcelona a través la mirada de la mujer. Quiere saber lo que verdaderamente vieron las mujeres en los balcones y las galerías del Eixample. 
La búsqueda de Esther Tusquets es diferente, como ya mencionado, no busca un sentido puramente filial, sino de pertenencia a una Barcelona íntimamente ligada a la clase burguesa. Aunque no fuera su propósito, en Tusquets se detecta una sombra de atavismo burgués, de este grupo social que creía que Barcelona les pertenecía, como pertenecían las mujeres a sus esposos. Si para Roig lo esencial es ser una mujer catalana, y buscar su propio origen en el de Barcelona, para Tusquets parece serlo el ser una burguesa barcelonesa y a esta dimensión le falta un "algo". No se siente en Tusquets el cariño que Roig tiene para su cuidad, esta intimidad, familiaridad, ese tuteo con la ciudad, es lo que falta en su relación con Barcelona. Además, el hecho de escribir en español, establece en sí, un desfase entre Barcelona y la autora. Sobre este tema, me parece interesante señalar la importancia del simbolismo de la lengua, cuando habla de la casa de les Punxes, obra típicamente catalana y barcelonesa, lo dice en catalán, no usa el nombre oficial de la casa de Terrades ni tampoco lo dice en español que sería la casa de los Punchos, (como lo hace cuando habla del Ensanche y no el Eixample). Este reflejo lingüístico indica el vínculo inherente de la cultura e identidad catalana con Barcelona. Se puede decir que el catalán se impone a Tusquets y pudiera significar que de cierta manera, solo se logra entrar o conocer verdaderamente la ciudad por sus nombres legítimos. La catalanidad de Barcelona es intrínseca a su identidad de hecho, describiendo la casa de les Punxes, Tusquets menciona otro detalle de prima importancia: "En la parte alta del edificio, un mosaico que representaba a san Jorge y el dragón, y un letrero que decía 'Sant Patró de Catalunya, torneu-nos la llibertat”’(136-7) es una proclamación doblemente transgresora por el contenido y la lengua (al mismo tiempo, proclamar la libertad de Cataluña en una lengua que no sea el catalán sería en sí 
una aberración ). Con esta cita, Sant Jordi el patrón de Catalunya afirma, indubitablemente desde 1456 la catalanidad de Barcelona y de su pueblo no solo en el espacio sino también en su historia. 
${ }^{1}$ Carmen Balcells, catalana y coetánea de Esther Tusquets es una de las agentes literarias más poderosas y conocidas en el mundo de las letras en catalán y en castellano. Es la agente de autores mundialmente reconocidos como Gabriel García Márquez, Mario Vargas Llosa en la literatura latinoamericana. Además, algunos autores, como Max Aub, Manuel Vázquez Montalbán o José Donoso la hicieron aparecer como personaje en algunas de sus novelas.

${ }^{2}$ Son una generación de escritoras que iniciaran lo que más tarde se llamaría el boom de la literatura femenina en España durante los años setenta, década en la cual se publicaron muchos artículos sobre literatura femenina.

${ }^{3}$ La gauche divine: Su nombre, "afortunada expresión periodística", como la llamó el editor Carlos Barrai (A. Moix, 24 horas 66), aparece por primera vez en octubre de 1967 en una de las "Rumbas" que publicaba Joan de Sagarra en el diario barcelonés

TeleleXprés1. Con ella se refería a la progresía de la ciudad que había acudido a la presentación de la editorial Tusquets. La etiqueta fue aceptada con agrado por parte de sus miembros debido, precisamente, a la provocadora contradicción entre gauche y divine con la que se distanciaban de la "derecha satánica" del régimen como recuerda Román Gubern (Rubio 29) y de la izquierda ortodoxa, reacia a los lemas de la revolución sexual y al anarquismo del mayo francés. Y así, algunos de sus miembros no hacían más que aumentar la confusión sugiriendo, en palabras de Oriol Regás, que se trataba de gente de izquierdas que hacía todo lo posible por vivir como gente de derechas (A. Moix, 24 horas 88).

Villamandos, Alberto. El Discreto Encanto De La Subversión: Una Crítica Cultural De La "gauche Divine". Pamplona: Editorial Laetoli, 2011.2. Print.

${ }^{4}$ George Sand. 1804-1876. Seudónimo de Amandine Aurore Lucie Dupin, baronesa Dudevant, novelista francesa del movimiento romántico. Sand fue una escritora enormemente prolífica que expresaba en sus obras una fuerte preocupación por los problemas humanos y los ideales feministas.

${ }^{5}$ Véase el estudio de Donna C. Stanton, Autogynography "Is the Subject Different?" in the Female Autograph. Theory and Practice of Autogynography: from the Tenth to the Twentieth century.

${ }^{6}$ Elaine Showalter. "A Literature of Their Own. British Women Novelists from Bronte Lessing”, Princeton University Press, Princeton, 1977, p. 13.

${ }^{7}$ « Pues bien, muerto Franco (casi) todo el mundo se puso a escribir sus memorias. El género se puso de moda y tuvo, en consecuencia, un gran eco. Un cambio de rasante se había producido. De ahí, que lo autobiográfico germinó con una inusitada fuerza y los españoles - tan acostumbrados a perder el tren en otras épocas - se iban a subir en el de alta velocidad de la literatura íntima », José Romera Castillo, De primera mano. Sobre escritura autobiográfica en España, Madrid, Visor, 2006, p. 23. 
${ }^{8}$ Philippe Lejeune, Signes De Vie: Le Pacte Autobiographique 2. Paris: Seuil, 2005.63. Print.

${ }^{9}$ Ladimer,Bethany. Colette, Beauvoir, and Duras. Age and women writers. Gainsville, University of Florida Press, 1999

${ }^{10}$ Joan W. Scott, "Experience" en Judith Butler y Joan W. Scott, Feminists Theorize the Political. Explican que: "Subjects are constituted discursively, experience is a linguistic event (doesn't happen outside established meanings), but neither it is confined to a fixed order of meaning. Since discourse is by definition shared, experience is collective as well as individual. Experience is subject's history. Language is the site of history's enactment. Historical explanation cannot, therefore, separate the two" (34)

${ }^{11}$ En Martine Watson Brownley y Allison B. Kimmich. Women and Autobiography. Explican que: "Like autobiography, which slips in and out of genre definitions, self is both culturally constituted and composed of all that culture would erase-rather like a fishnet, composed both of string and empty spaces between the fibers. Or a skein of tangle yarn that cannot successfully be untangled-where knots and frayed elements remain." (12)

${ }^{12}$ La autobiografía, según explica George May, es una forma de decodificar la vida humana y poder darle unidad y coherencia al pasado para poder recuperarlo y revivirlo en el presente (37).

${ }^{13}$ Oscar sin acento en el texto.

${ }^{14}$ Véase el artículo “Juan Marsé gana el Premio Cervantes”. El País 26 Nov. 2008. El país.com.Web. 10 Nov.2011.

${ }^{15}$ Pierre Nora (1931), es un historiador francés, conocido por sus trabajos sobre la identidad francesa y la memoria, el oficio del historiador así como su papel en la edición en ciencias sociales. Es el representante más significativo de la llamada nueva historia. Ocupa una posición particular, que él mismo califica de lateral, en la historiografía francesa.

${ }^{16}$ Paul Ricoeur, ( 1913 -2005) fue un filósofo y antropólogo francés conocido por su intento de combinar la descripción fenomenológica con la interpretación hermenéutica.

${ }^{17}$ Els catalans als camps nazis publicado en 1977 ilustra perfectamente el deber de memoria según el concepto de Paul Ricoeur, ya que se trata de devolver la memoria a los republicanos en los campos de concentraciones nazis durante la Segunda Guerra Mundial con el propósito de quebrar el silencio impuesto por el Franquismo quien negó y ocultó la realidad de la deportación 
18 Conde de Barcelona (1097-1131). Hijo de Ramón Berenguer II, nació poco tiempo antes de que su padre fuera asesinado, supuestamente por instigación de su hermano Berenguer Ramón II. Tras el destierro de éste en 1096, Ramón Berenguer III se convirtió en conde de Barcelona, e inició una política de fortalecimiento de su Casa repecto a los demás señores feudales de la zona. Dentro de esta política hay que enmarcar la inclusión en sus dominios del condado de Besalú, a la muerte de Bernat III, en 1111, así como su boda, al año siguiente, con Dulce de Provenza, que le reportó los derechos sobre este condado.

En 1117 heredó la Cerdaña al morir sin sucesión el conde Bernat Guillem, y en los años siguientes firmó diversas alianzas con Foix, Urgell, Pallars y el Rosellón. Su política exterior se caracterizó por una orientación hacia el sur para contrarrestar el peligro de los almorávides, cuyas incursiones amenazaban el Penedés y el Vallés. Con todo, su estrategia no fue sólo defensiva, ya que estuvo al frente de una expedición naval pisana que, bajo el patrocinio del Papa, ocupó Mallorca e Ibiza.

Ramon BerenguerIII. Bibliografias y Vidas, 2004-1.Web. 10 November 2012.

${ }^{18}$ Selfactinas : f. ingen. mecán. Máquina automática discontinua, para la hilatura. Su órgano principal es un carro que contiene los husos en rotación y que está dotado de un movimiento de avance y retroceso. Una antigua variedad de esta máquina hecha en Cataluña tomó el nombre de bergadana.

Diccionario Enciclopédico Vox 1. 2009 Larousse Editorial, S.L. Web. 3 Jan. 2013. $<$ http://es.thefreedictionary.com/selfactinas $>$

${ }^{19}$ Maurice Halbwachs fue un sociólogo francés de la escuela durkheimiana, nacido en Reims el 11 de marzo de 1877 y fallecido en el campo nazi de Buchenwald el 16 de marzo de 1945, donde fue deportado.

${ }^{20}$ La casa Terrades o la casa de las Punxes (pinchos en castellano) fue construida en 1905 por el arquitecto catalán Josep Puig i Cadafalch. Esta casa se sitúa en la avenida Diagonal de Barcelona.

${ }^{21}$ Pedralbes, barrio de Barcelona es parte del distrito de las Corts. Pedralbes es hoy la zona residencial de más alto standing de Barcelona, con grandes mansiones -antiguas y nuevas- rodeadas de jardín, como en el entorno a la avenida Pearson y del parque de la Oreneta, o bloques aislados, como en los entornos de la avenida de Pedralbes y de la carretera de Esplugues. El barrio incluye, en su extremo occidental, el conjunto o pequeño barrio de La Mercè, creado el año 1946 con el nombre de Las Cinco Rosas, haciendo referencia a uno de los símbolos de la Falange. El Instituto Nacional de la Vivienda edificó 123 viviendas protegidas que, el año 1981, pasaron al patrimonio social urbano. El barrio incluye el gran parque Cervantes, el cuartel del Bruc, los jardines y el palacio real de Pedralbes, así como el Campus Norte de la Zona Universitària. También cabe destacar la finca Güell, de Gaudí, con el conocido dragón en el forjado de su entrada. En el extremo oriental, entre la avenida de Pedralbes y la Ronda del Mig, se encuentra el sector residencial de la Font dels Ocellets - Santa Gemma. Ajuntament de Barcelona. "Les corts".Web. 27 Jan. 2013. $<$ http://w110.bcn.cat/portal/site/LesCorts/menuitem/> 
${ }^{22}$ La Rambla de Cataluña (en catalán Rambla de Catalunya) es una de las vías más céntricas de Barcelona (España), que discurre por la derecha del Ensanche en dirección mar-montaña entre el Paseo de Gracia y la calle de Balmes.

Nace en la plaza de Cataluña y acaba en la Avenida Diagonal. Es un paseo básicamente comercial donde abundan las tiendas de moda. En la actualidad hay dos salas de cine: el Club Coliseum y el Alexandra, que integra diversas salas y la pequeña sala Alexis. En el pasado en el número 3 se encontraba el desaparecido Teatro Barcelona, y otros cines han ido desapareciendo con el tiempo, como el Alcázar. "Rambla Cataluña ." Wikipedia: The Free Encyclopedia. Wikimedia Foundation, Inc. 6 Jan 2013. Web. 10 Jan. 2013. $<$ http://en.wikipedia.org/wiki/Rambla Cataluña $>$

${ }^{23}$ Aunque el Modernismo fue un estilo arquitectónico y decorativo que, como otros estilos, después de su periodo de máximo apogeo, se vio como un arte caduco, prefiriéndose estilos más funcionales y menos barrocos. Este rechazo, por parte de las clases altas de la Posguerra constituyó también cierto rechazo del catalanismo, ya que ningún otro estilo arquitectónico puede considerarse más emblemático del nacionalismo catalán, con el que se identifican de manera implícita o explícita (como puede verse en el mensaje independentista en la Casa de les Punxes) los elementos decorativos que lo revisten.

${ }^{24}$ Me refiero por ejemplo a El carrer de las camèlies de Mercè Rodoreda o El temps de las cireres, entre otras.

${ }^{25}$ Gabriel Ferrater: No hi vam entrar. Fèim la muda, i no trobàrem interés en el parracs

de vella pell. Oloràrem la por que era l'aroma d'aquella tardor... (22)

(Reus, 1922 - Sant Cugat del Vallès, 1972). Escritor y lingüista. Autor de una de las más relevantes obras poéticas de la literatura catalana de posguerra, con sólo tres libros: $D a$ nuces pueris (1960), Menja't una cama (1962) y Teoria dels cossos (1966), reunidos después en el volumen Les dones $i$ els dies (1968), que supuso el punto final de una aventura poética insólita en el marco de las letras catalanas. "Gabriel Ferrater."

Wikipedia: The Free Encyclopedia. Wikimedia Foundation, Inc. 5Jan 2013. Web. 10 Jan. 2013. <http://en.wikipedia.org/wiki/Gabriel Ferrater >

${ }^{25}$ Louis Ferdinand Auguste Destouches ,(1894-1961) mejor conocido por LouisFerdinand Céline, fue un escritor y médico francés. Fue uno de los escritores franceses más controversiales del siglo XX, por crear su propio estilo de escritura y también su literatura antisemita. Sin embargo, influenció mucho la literatura francesa y extranjera. Es uno de los autores más traducidos y su novela más conocida es Viaje al film de la noche. 
pagos, verdad, están acostadas, las ciudades, al borde del mar o a la orilla de ríos, se extienden sobre el paisaje, esperan al viajero, mientras que aquélla, la americana, no se despatarraba, no, se mantenía bien estirada, ahí, cachonda, estirada como para asustar. Céline, Ferdinand. Trad. Carlos Manzanos, Viaje al fin de la noche. La edición virtual .2009. Web. 27 Jan.2013. http://www.laeditorialvirtual.com.ar/Pages2/Celine/ 


\section{Conclusión}

Sin duda, el siglo XX representa una época esencial en la cual el recrudecimiento de los trabajos sobre ciudad y literatura muestra la importancia que se le presta al espacio urbano en el mundo literario actual. Como hemos podido comprobar, frente a una literatura urbana, ampliamente reconocida y estudiada dentro del corpus masculino, surge poco a poco una escritura sobre el espacio urbano femenino, producida por un grupo de escritoras que se sientan comprometidas no solo con los problemas específicamente femeninos sino también con los literarios, entre los cuales se destacan la voluntad de recuperación y de apropiación del espacio urbano a través de su literatura. Tanto en sus novelas como en sus autobiografias, las escritoras catalanas tratan de recobrar Barcelona denunciando de manera explícita o implícita el entorno en el cual el sistema patriarcal les había negado y el trato al que han sido sometidas.

En su novela La fabricanta, la reivindicación de Monserdà, a pesar de ser llevada a cabo de forma moderada y desde su feminismo conservador, dio palabra y vida a una mujer catalana, capaz de triunfar ante situaciones imposibles de superar por los hombres. La autora a través de los rasgos de Antonieta esboza una nueva concepción de Barcelona y de la mujer. En realidad, si pensamos en las teorías de la novela fundacional desarrolladas por Doris Sommer, es posible afirmar que la protagonista de Monserdà tiene una función de metáfora, es una imagen no de Catalunya, sino de la fundación de las bases de la Barcelona moderna. Asimismo, la construcción de su personaje supone también una proclamación del nacionalismo de Monserdà, escindido entre añoranza por 
un pasado artesano y un futuro industrial, pero profundamente catalán como nos deja claro la elección del catalán como lengua literaria.

El tema de la protagonista cuya imagen se superpone a la de Barcelona parece ser un tema recurrente en la literatura urbana. Así es posible verlo también, en la novela de Capmany, Feliçment, jo soc una dona, en la que la autora superpone la historia de la protagonista con la de Barcelona entre los años 1900 y 1950. El relato estructurado como una ciudad; no se lee, se recorre y al igual que un paseo por sus calles, la descubrimos al mismo tiempo que la protagonista. El texto, y la ciudad, aparecen poco a poco, paso a paso, al azar de los pasos de la protagonista Carola. A pesar de un recorrido de los espacios urbanos sin planificación previa, el mapa que se esboza representa la realidad histórica y geográfica de Barcelona. Carola va por la ciudad y busca su vida de calle en calle. La sensación de perderse o de andar por el mismo rumbo es recurrente en el relato y transcribe dos cosas, por un lado supone el juego de la memoria que, a modo de caja de Pandora, deja escapar todos los recuerdos, pero sin orden ni garantía de que sea una rememoración agradable o dolorosa; por otro lado, tenemos un efecto fuertemente metafórico, pues Carola se busca a ella misma en todos estos dédalos tratando de construirse adoptando y substituyendo la historia de Barcelona por la de su familia. Se constituye entonces su personalidad con una estructura esquelética urbana a partir de la cual, Carola hace cuerpo con la ciudad. Todos los cambios de su vida, todas las diferentes Carolas representan las diferentes Barcelonas, pero con una misma constante: la brecha incompatible de las clases sociales. Por lo tanto, esta proyección de Barcelona visiblemente fragmentada en clases sociales puede leerse como una denuncia y, sin 
ninguna duda, sirve para legitimar su conciencia de clase y su solidaridad con el proletariado.

Por otro lado, la toma de la palabra se junta a la experiencia del espacio que deja de ser posesión exclusiva del hombre de modo que la ciudad como espacio masculino se va feminizando. Este nuevo relato de la ciudad feminizada va más allá que un simple discurso y se convierte en un lenguaje. Un lenguaje al servicio de la escritura de Capmany tanto del punto de vista lingüístico como del identitario. Por lo tanto, el catalán cimienta y unifica todo el texto y Barcelona frente al estado español que representa la desposesión de la cultura y de la identidad catalana construye no sólo una lenguacuerpo, sino también una lengua identidad por lo que nos encontramos ante una reivindicación totalmente nacionalista. Es fácil entender que, por la fecha de su producción, Capmany tuvo que escribir una novela palimpséstica y que para tapar su discurso tuvo que recurrir a la metalepsis. Con Feliçment, jo soc una dona, Capmany construye una relación entre ella y el lector invitándolo a un juego en el que cada indicio lleva a otro hasta desmantelar y deconstruir la historia oficial del franquismo.

En el último capítulo de este trabajo, Esther Tusquets nos ofrece en Habiamos ganado la guerra, un enfoque único, ya que presenta una Barcelona desde la visión franquista de su familia y pone en relieve la realidad político-social de los espacios urbanos barceloneses desde una perspectiva de mujer burguesa. A través de su memoria se construye una Barcelona exclusivamente burguesa, aunque se aluda brevemente a la vida que debían de tener las criadas. Por esta razón, es una visión, de cierta manera, incompleta de Barcelona, aunque sea totalmente real. En contrapunto, la narrativa de 
Montserrat Roig, hace hincapié en todas las capas de la clase social a través sus condiciones desde la vida de la mujer burguesa a la obrera.

Tusquets escribió su autobiografía para agregar "algo" a la historia de Barcelona, a una Barcelona casi siempre contada desde el lado de los vencidos y paralelamente, Roig, escribió Dime que me quieres aunque sea mentira, para llenar los vacíos de la literatura de la historia barcelonesa de la mujer. Ante lo expuesto, se puede decir que las dos escribieron para completar o mejorar la historia de la Ciudad condal . Sin embargo, la visión que nos ofrece Tusquets, aunque basada en la buena intención de querer contribuir a la historia de su ciudad, se orienta más bien en una búsqueda personal limitada a su entorno personal, cuando lo que Roig hace es más bien una búsqueda "genealógica" para la historia de la mujer barcelonesa. Con todo, a pesar de que Tusquets nos dé una visión acertada de la vida de la mujer burguesa en la Barcelona franquista de las posguerra, y que se presente como hija del Eixample, su relación de filiación con Barcelona falta de intimidad. Entretiene con "su" ciudad, como la llama, una relación más bien de posesión que de pertenencia y su verdadera búsqueda identitaria es más hacia su clase social y su pertenencia al clan de los Tusquets que a su identidad barcelonesa. Además, al escribir en castellano sobre la capital catalana, provoca una fisura identitaria entre la autora y su ciudad.

El propósito de este estudio ha sido, no solo dar a conocer la literatura urbana catalana a través de estas autores, sino también de establecer la necesidad y la importancia de demostrar que el uso de la ciudad en la literatura urbana femenina catalana, es el cuerpo del texto literario y que Barcelona establece y caracteriza las obras de estas escritoras. Gracias a esta escritura, donde se mezclan espacios, historia, 
clases y géneros, las escritoras catalanas han conscientemente querido que nazca otra historia de la ciudad: la de las mujeres como protagonistas ciudadanas, productoras, reproductoras y consumidoras del espacio representado por la Ciudad condal. También se ha establecido que la recuperación y la reivindicación literaria de Barcelona por las mujeres se ha hecho a través del texto escrito, como afirmación literaria y como toma de consciencia en la cual la ciudad no podía resumirse a un telón de fondo, sino ser parte activa de la creación literaria, activa en el doble sentido, como espacio social-histórico de la novela y como característica de sus obras.

Debo por lo tanto concluir afirmando que la narrativa urbana femenina, tanto las de las autoras estudiadas como de las que no figuran en este estudio, ha contribuido a la recuperación del espacio femenino de Barcelona. Asimismo, la necesidad para la mujer de recuperar y reescribir su historia como parte de la historia de Barcelona, parece ser en el tumultuoso entorno actual, más que nunca, una urgencia para poder llegar a una toma de consciencia y a una reposesión de lo que les pertenece. La proclamación y la existencia a través de la escritura inplica su arraigo y su pertenencia con Barcelona, imponiéndose como un componente identitario indisociable y esencial del pueblo catalán. 


\section{BIBLIOGRAFÍA}

Aldaraca, Bridget. El Ángel Del Hogar: Galdós and the Ideology of Domesticity in Spain. Chapel Hill: Dept. of Romance Languages, University of North Carolina, 1992. Print.

Amorós, i P. D. La Imatge De La Dona En L'obra De Maria Aurèlia Capmany (19181991): L'espai Entre La Reflexió Crítica I La Creació Literària. Sant Vicent del Raspeig (Alicante: Centre de Estudios sobre la Mujer $=$ Centre d'Estudis sobre

la Dona, 2002. 15. Print.

Bachelard, Gaston. La Poétique De L'espace. Paris: Presses universitaires de France, 1970. 92.119. Print.

Bajtin, Mijail M. The Dialogic Imagination: Four Essays. Austin: University of Texas Press, 1994. 247. Print.

Barthes, Roland, and Honoré. Balzac. S/z. Paris: Éditions du Seuil, 1970. 61.Print.

---. Roland Barthes. Paris: Seuil, 1975. Print.

---.Barthes, Roland. La Chambre Claire: Note Sur La Photographie. Paris: Gallimard, 1980. 61. Print.

Bourneuf, Roland, and Réal Ouellet. L'univers Du Roman. Paris: Presses universitaires de France, 1972. 72. Print.

Balzac, Honoré, d'Aurevilly J. Barbey, Charles Baudelaire, and Roger Kempf. Sur Le Dandysme ; Traité De La Vie Élégante. Paris: Union générale d'éditions, 1971. Print.

Benjamin, Walter, and Rolf Tiedemann. Paris, Capitale Du Xixe Siècle: Le Livre Des Passages. Paris: Les Éditions du Cerf, 1989. Print.

Broch, Alex. Literatura Catalana Dels Anys Setanta. Barcelona: Edicions 62, 1980. Print.

Butler, Judith, and Joan W. Scott. Feminists Theorize the Political. New York: Routledge, 1992. 34.Print.

Brownley, Martine W, and Allison B. Kimmich. Women and Autobiography.

Wilmington, Del: SR Books, 1999. 34. Print. 
Caballé, Anna, Tania Pleitez, Mas M. Prado, and Garretas M.-M. Rivera. La Vida Escrita Por Las Mujeres. Barcelona: Lumen, 2004. 112. Print.

Capel, Sáez H. Capitalismo Y Morfología Urbana En España. Barcelona: J. Batlló, 1975. Print

Capmany, Maria A, and Guillem-Jordi Graells. Obra Completa. Barcelona: Columna, 1993. Print.

Capmany, Maria A. Feliçment, Jo Sóc Una Dona. Barcelona: Editorial Laia, 1983. Print.

---. La Dona a Catalunya: Consciència I Situació. Barcelona: Edicions 62, 1966. 20. Print.

---. Carta Abierta Al Macho Ibérico. Madrid: Ediciones 99, 1973. Print.

---. El feminisme a Catalunya. Barcelona: Nova Terra, 1973. 45. Print.

---. "Montserrat Roig, offici i plaer de viure i escriure", Cultura (abril):16. Print.

---. Lo Color Més Blau. Barcelona: Planeta, 1983. 18. Print.

---. Maragall, Pasqual, and Maria A. Capmany. Pasqual Maragall, Caminant Junts Per La Ciutat. Barcelona: Editorial Laia, 1984. 47. Print.

---. Això Era I No Era. Barcelona (Espanya: Planeta, 1989. Print

---. De Profesión, Mujer. Barcelona: Plaza \& Janes, 1971. Print.

Carabí, Angels, and Marta Segarra. Mujeres Y Literatura. Barcelona: PPU, 1994. Print.

Céline, Louis-Ferdinand. Voyage Au Bout De La Nuit. Paris: Gallimard, 1952.152. Print.

Charlon, Anne, and Maurice Molho. Condition Feminine Et Roman Feminin Dans La Catalogne Contemporaine (1893-1983). S.1.: s.n., 1987. Print.

Charlon, Anne. La Condició De La Dona En La Narrativa Femenina Catalana: 19001983. Barcelona: Edicions 62, 1990. 31. 37.45.62 85. .Print.

---."El feminisme en la narrativa catalana contemporània," L'Aiguadolç. 4, ( (1987), 9-30..Print.

---. Casacuberta, Margarida, Marina Gustà, and Gómez M. I. Seguro. Urban Narratives: The Literary Construction of Barcelona. Barcelona: Fundacio Antonitapies, 2010. Print. 
Ciplijauskaité, Biruté. La Novela Femenina Contemporánea (1970-1985): Hacia Una Tipología De La Narración En Primera Persona. Barcelona: Anthropos, 1988. 16. Print.

Cixous, Hélène, and Catherine Clément. La Jeune Née. Paris: Union générale d'éditions, 1975. 34. Print

---. Le Rire De La Méduse. Paris: Galilée, 2010. Print.

Compagnon, Antoine, Jean-Baptiste Amadieu, and Annick Bouillaguet. Proust, La Mémoire Et La Littérature: Séminaire 2006-2007 Au Collège De France. Paris: Odile Jacob, 2009. Print.

Cruz, Manuel. Las Malas Pasadas Del Pasado: Identidad, Responsabilidad, Historia. Barcelona: Editorial Anagrama, 2005. Print.

Cuevas, García C, and Enrique Baena. Escribir Mujer: Narradoras Españolas Hoy. Málaga [Spain: Publicaciones del Congreso de Literatura Española Contemporánea, 2000. Print.

Davies, Catherine. Spanish Women's Writing, 1849-1996. London: Athlone Press, 1998. 6,174. Print.

Doubrovsky, Serge. Autobiographiques: De Corneille a Sartre. Paris: Presses universitaires de France, 1988. Print.

Mérimée, Prosper, and Prosper Mérimée. Colomba: And Carmen. New York: P.F. Collier 1901. Print.

Di, Méo G. Les Murs Invisibles: Femmes, Genre Et Géographie Sociale. Paris: A. Colin, 2011. Print.

Dupláa, Cristina. La Voz Testimonial En Montserrat Roig: Estudio Cultural De Los Textos. Barcelona: Icaria, 1996. Print.

---. "Montserrat Roig: una Barcelona más". Centro virtual Cervantes. Acta XIII

Congreso AIH tomo IV:

$23<\mathrm{hhtp} /$ :cvc.cervantes.es/literature/ain/pdf/113/aih_13_4_010.pdf $>\quad$ Web. 30 Nov. 2012

---. "Los lugares de la memoria en la Barcelona de Montserrat Roig" Revista Hispánica Moderna ser. 54.1 (Jun.2001): 166-75. Print. 
Ealham, Chris: Class and the City: Memories of Pleasure and Danger in Barcelona. 191423. Oral History. Vol. 29, No.1, Pleasure and the City (Spring, 2001) pp. 33-37. Published by :Oral History Society.

Edo, Benaiges P. Dones I Ciutat a La Barcelona Del Segle Xx: Una Anàlisi Geogràfica a Través De La Literatura. Bellaterra: Universitat Autònoma de Barcelona, 2005. 67.326. Web.<http://www.tdx.cat/bitstream/handle/10803/4961/peb1de3.pdf $>$

Eulate, Sanjurjo C, and Angel M. Aguirre. La Muñeca. San Juan, P.R: Editorial del Instituto de Cultura Puertorrigueña, 1987. Print.

Farrugia, Francis. "Sindrome Narrativo Y Reconstruccion Del Pasado." Historia, Antropologia Y Fuentes Orales (barcelona). (2004): 133-150. Print.

Fernández, Prieto C, Alvarez M. A. Hermosilla, and Anna Caballé. Autobiografía En España: Un Balance: Actas Del Congreso Internacional Celebrado En La Facultad De Filosofía Y Letras De Córdoba Del 25 Al 27 De Octubre De 2001. Madrid: Visor Libros, 2004. Print.

Ferrán, Ofelia. Working Through Memory: Writing and Remembrance in Contemporary Spanish Narrative. Lewisburg: Bucknell University Press, 2007. Print.

Freixas, Laura. Literatura Y Mujeres: Escritoras, Público Y Crítica En La España Actual. Barcelona: Destino, 2000. Print

Fuster,Joan : Literatura catalana contemporánea, Barcelona, Curial, 1980. 78. Print.

---.Contra el nacionalisme espanyol / Joan Fuster; introducció i selecció de textos cura de Jaume Pérez Muntaner. Barcelona: Curial, 1994. Print.

Gabancho, Patrícia. Cultura Rima Amb Confitura: Bases Per a Un Debat Sobre La Literatura Catalana. Barcelona: Edicions 62, 1980. Print.

---. La Rateta Encara Escombra L'escaleta: (cop D'ull a L'actual Literatura Catalana De Dona). Barcelona: Edicions 62, 1982. 48. Print.

Garber, Judith A, and Robyne S. Turner. Gender in Urban Research. Thousand Oaks, Calif: Sage Publications, 1995. Print.

Garric, Henri. Portraits De Villes: Marches Et Cartes : La Représentation Urbaine Dans Les Discours Contemporains. Paris: H. Champion, 2007. Print.

Gelfant, Blanche H. The American City Novel: Theodore Dreiser, Thomas Wolfe, Sherwood Anderson, Edith Wharton, John Dos Passos, James T. Farrell, Nelson 
Algren, Betty Smith, Leonard Bishop, Willard Motley, and Others. Norman: University of Oklahoma Press, 1970. Print.

Genette, Gérard. Nouveau Discours Du Récit. Paris: Editions du Seuil, 1983. 64.Print.

---. Figures: Essais. Paris: Editions du Seuil, 1966. Print.

Glenn, Kathleen. "First Person Singular:MontserratmRoig and the Essay" . Catalan Review, XI, (1995). 84. Print.

Glenn, Kathleen M, and de R. M. Mazquiarán. Spanish Women Writers and the Essay: Gender, Politics, and the Self. Columbia: University of Missouri Press, 1998.

Print.

Gottdiener, Mark, and Alexandros P. Lagopoulos. The City and the Sign: An Introduction to Urban Semiotics. New York: Columbia University Press, 1986. Print.

Halbwachs Halbwachs, Maurice, and Gérard Namer. Les Cadres Sociaux De La Mémoire. Paris: Albin Michel, 1994. 145. Print.

Halbwachs, Maurice, Gérard Namer, and Marie Jaisson. La Mémoire Collective. Paris: A. Michel, 1997. Print.

Hovig Ter Minassian, "Le paysage de la gentrification à Barcelone", Strates.13, 2008, Web 22 Jan 2011. <http://strates.revues.org/6312/>

Hutcheon, Linda. A Poetics of Postmodernism: History, Theory, Fiction. New York: Routledge, 1988. Print.

Irigaray, Luce. Ethique De La Différence Sexuelle. Paris: Editions de Minuit, 1984.132. Print.

King, Stewart R. Escribir La Catalanidad: Lengua E Identidades Culturales En La Narrativa Contemporánea De Cataluña. Woodbridge: Tamesis, 2005. Print.

Ladimer, Bethany. Colette, Beauvoir, and Duras: Age and Women Writers. Gainesville: University Press of Florida, 1999. Print.

Laforet, Carmen. Nada. New York: Oxford University Press, 1958. Print.

Laronde, Michel Autour Du Roman Beur: Immigration Et Identité. Paris: L'Harmattan, 1993. 67. Print.

Lehan, Richard D. The City in Literature: An Intellectual and Cultural History. Berkeley: University of California Press, 1998. 45. Print. 
Le, Wita B. Ni Vue Ni Connue: Approche Ethnographique De La Culture Bourgeoise. Paris: Maison des sciences de l'homme, 1988. 178. Print.

Le, Goff J. El Orden De La Memoria: El Tiempo Como Imaginario. Barcelona: Ediciones Paidós, 1991. 134.138. Print.

Lejeune, Philippe. Le Pacte Autobiographique. Paris: Seuil, 1975. 15. 22. Print.

---. Signes De Vie: Le Pacte Autobiographique 2. Paris: Seuil, 2005.63. Print.

Lluèsia, Julià: Memòria de L'aigua: Onze Escriptores I el Seu Món, Barcelona: Proa, (2003) 96. Print.

López-Cabrales, María M. Palabras De Mujeres: Escritoras Españolas Contemporáneas. Madrid: Narcea, 2000. Print.

Macciuci, Raquel, Muro M. T. Pochat, and Juan A. Ennis. Entre La Memoria Propia Y La Ajena: Tendencias Y Debates En La Narrativa Española Actual. La Plata, Argentina: Ediciones del Lado de Acá, 2010. Print.

Manteiga, Robert C, Carolyn L. Galerstein, and Kathleen McNerney. Feminine Concerns in Contemporary Spanish Fiction by Women. Potomac, Md., U.S.A: Scripta Humanistica, 1988. Print.

Maragall, Pasqual. Pasqual Maragall, caminant junts per la ciutat / Maria Aurèlia Capmany ; conversa transcrita per Xavier Febrés. Barcelona : Editorial Laia, 1984.

Masanet, Lydia. La Autobiografía Femenina Española Contemporánea. Madrid: Editorial Fundamentos, 1998. Print.

May, Georges. La Autobiografía, México. D. F., FCE, 1982. Print.

McDowell, Linda. Gender, Identity, and Place: Understanding Feminist Geographies. Minneapolis: University of Minnesota Press, 1999. Print.

McNerney, Kathleen. On Our Own Behalf: Women's Tales from Catalonia. Lincoln: University of Nebraska Press, 1988. Print.(p.10)

Melgar-Foraster, Shaudin. El Discurso Narrativo De Dos Escritoras Contemporáneas De Barcelona: Estudio De L'hora Violeta De Montserrat Roig Y De Para No Volver De Esther Tusquets. Ottawa: National Library of Canada = Bibliothèque nationale du Canada, 1996. Print. p.276 
Miranne, Kristine B, and Alma H. Young. Gendering the City: Women, Boundaries, and Visions or Urban Life. Lanham: Rowman \& Littlefield, 2000. Print.

Mitterand, Henri. Zola, Émile, Armand Lanoux, and Henri Mitterand. Les RougonMacquart: Histoire Naturelle Et Sociale D'une Famille Sous Le Second Empire. Paris: Gallimard, 1960. Print.

---. Le lieu et le sens:l'espace parisien dans Ferragus de Balzac. Gallimard, 1980. 86. Print.

Monserdá, de M. D. La Fabricanta: Novel-la De Costums Barcelonines (1860-1875). Barcelona: Edicions de l'Eixample, 1992. Print.

Molinaro, Nina L, and Esther Tusquets. Foucault, Feminism, and Power: Reading Esther Tusquets. Lewisburg: Bucknell University Press, 1991. Print.

Nichols, Geraldine C. Des/cifrar La Diferencia: Narrativa Femenina De La España Contemporánea. México, D.F: Siglo Veintiuno Editores, 1992. 35. Print.

---. Escribir, Espacio Propio: Laforet, Matute, Moix, Tusquets, Riera Y Roig Por Si Mismas. Minneapolis, Minn: Institute for the Study of Ideologies and Literature, 1989. 47. Print.

Nora, Pierre. Les Lieux De Mémoire. Paris: Editions Gallimard, 1997. Print.

Oyón, José L. La Quiebra De La Ciudad Popular: Espacio Urbano, Inmigración Y Anarquismo En La Barcelona De Entreguerras, 1914-1936. Barcelona: Ediciones del Serbal, 2008. Print.

Palau, Montserrat. Paraula De Dona: Actes Del Col-loqui Dones, Literatura I Mitjans De Comunicació : Tarragona Del 26 Al 29 D'abril De 1995. Tarragona: Diputació de Tarragona, 1997. 72. Print.

---. "La mística de la feminitat franquista a la narrativa de maria Aurèlia Capmany", Catalan Review, vol 7, núm. 2 (1993) pp 86-87.p7. Print.

Pardo, Bazán E. La Tribuna. Madrid: Taurus, 1968. Print.

Plate,Liedeke. Transforming Memories in Contemporary Women's Rewriting. Basingstoke, Hampshire: Palgrave Macmillan, 2011. Print.

Platonov, Henry. Le corps de Moscou. Stanford, Calif: Stanford Uni versity Press, 2008. 21.Print.

Pike, Burton. The Image of the City in Modern Literature. Princeton, N.J: Princeton University Press, 1981. 3. Print. 
Resina, Joan R. Barcelona's Vocation of Modernity: Rise and Decline of an Urban Image. Stanford, Calif: Stanford University Press, 2008. 21. Print.

Ricœur, Paul. Temps Et Récit. Paris: Seuil, 1983. 110. Print.

---. La Mémoire, L'histoire, L'oubli. Paris: Seuil, 2000. Print.

Roca, i A. J. Expansió Urbana I Planejament a Barcelona. Barcelona: Institut Municipal d'Història de Barcelona, Ajuntament de Barcelona, Institut de Cultura, 1997.

Print.

Roca i Albert Joan et Faigenbaum Patrick, "Le front de mer de Barcelone : chronique d'une transformation", Cités, 3 n $^{\circ} 11$, (2002) :49-62. Print

Rodoreda, Mercè. El Carrer De Les Camèlies. Barcelona: Editorial Planeta, 1970. Print.

Romera, Castillo J. "Traducciones De Literatura Autobiografica." Quimera; Revista De Literatura (barcelona). (2004): 39-42. Print.

Ricœur, Paul. Temps Et Récit. Paris: Seuil, 1983. 110. Print.

---. La Mémoire, L'histoire, L'oubli. Paris: Seuil, 2000. Print.

Rodrigo, Antonina. Mujeres De España: (las Silenciadas). Esplugas de Llobregat (Barcelona: Plaza \& Janés, 1979. Print.

Roig, Montserrat. Dime Que Me Quieres Aunque Sea Mentira: Sobre El Placer Solitario De Escribir Y El Vicio Compartido De Leer. Barcelona, Spain: Ediciones Península, 1992. Print.

---. Molta roba i poc sabó...i tan neta que la volen. Barcelona: Edicions 62, 1971. Print.

---. Ramona, Adéu. Barcelona: Edicions 62, 1976. Print.

---. Els Catalans Als Camps Nazis. Barcelona: Edicions 62, 1977. Print.

---..El Temps De Les Cireres. Barcelona: Edicions 62, 1977. Print.

---. L'òpera Quotidiana. Barcelona: Planeta, 1982. Print.

---. “Ofici i plaer de viure i escriure”. Cultuta (1991, Abril). 13-26. Print.

---. L'hora Violeta. Barcelona: Ediciones 62, 1993. Print.

Roy, Joaquín. Barcelona in literature : Iberian Studies Institute, North-South Center, University of Miami, 1990. Print. 
Saint-Exupéry, Antoine. Le Petit Prince. San Diego: Harcourt, 2001.34. Print.

Sánchez, Alexandre. Barcelona, 1888-1929: Modernidad, Ambición Y Conflictos De Una Ciudad Soñada. Madrid: Alianza Editorial, 1994. Print.

Sansot, Pierre. Poétique De La Ville. Paris: Klincksieck, 1971. Print.

Shaudin Melgar-Foraster. "L'hora violeta y Para no volver dos lenguas, Barcelona y la mujer”. Revista Canadiense de Estudios Hispánicos.Vol. 26, No. 1/2, J. (2001 / 2002): 155-165. JTSOR. <http://www.jstor.org/stable/27763760/>. Web 20 Jun. 2011.

Sizemore, Christine W. A Female Vision of the City: London in the Novels of Five British Women. Knoxville: University of Tennessee Press, 1989. Print.

Solanas, Juan V. Historia De La Literatura Catalana. Miami, Fla: Ediciones Universal, 1980. Print.

Sommer, Doris. Foundational Fictions: The National Romances of Latin America. Berkeley: University of California Press, 1991. 5. Internet resource.

Squier, Susan M. Women Writers and the City: Essays in Feminist Literary Criticism. Knoxville: University of Tennessee Press, 1984. Print.

---. Virginia Woolf and London: The Sexual Politics of the City. Chapel Hill: University of North Carolina Press, 1985. Print.

Stanton, Domna C, and Jeanine P. Plottel. The Female Autograph. New York: New York Literary Forum, 1984. 3. Print.

Stendhal, and Henri Martineau. De L'amour. Paris: Éditions Garnier frères, 1959. Print.

Terlinden, Ulla. City and Gender: International Discourse on Gender, Urbanism, and Architecture. Opladen: Leske + Budrich, 2003. Print.

Todorov, Tzvetan, and Crespo M. Serrat. Memoria Del Mal, Tentación Del Bien: Indagación Sobre El Siglo XX. Barcelona: Península, 2002. 159. Print.

---. Memory As a Remedy for Evil. Kolkata: Seagull Books.2010. Print.

Tous Rovirosa, Anna. "Montserrat Roig. Periodismo comprometido y activismo social en la transición democrática española". XII Congreso de la Asociación de Historiadores de la Comunicación. Universitat Pompeu Fabra, Barcelona,2012.

Print.

Tusquets, Esther. Confesiones De Una Editora Poco Mentirosa. Barcelona: RqueR E, Editorial, 2005. Print. 
---. Habiamos Ganado La Guerra. Barcelona: Bruguera, 2007. Print.

---. Confesiones De Una Vieja Dama Indigna. Barcelona: Bruguera, 2009. Print.

---. Tiempos que no fueron. Barcelona. Bruguera, 1012. Print.

---. El Mismo Mar De Todos Los Veranos. Barcelona; Lumen S.A., 1978. Print.

---. Para No Volver. Barcelona: Editorial Lumen, 1985. Print.

---. El amor es un juego solitario. Barcelona: Lumen S.A., 1979. Print.

---. Varada tras el último naufragio. Barcelona: Lumen S.A., 1980. Print.

---. Siete miradas en un mismo paisaje. Barcelona: Lumen S.A., 1981. Print.

---. Carta a La Madre Y Cuentos Completos. Palencia: Menoscuarto Ediciones, 2009. Print

Sizemore, Christine W. A Female Vision of the City: London in the Novels of Five British Women. Knoxville: University of Tennessee Press, 1989. Print.

Villamandos, Alberto. El Discreto Encanto De La Subversión: Una Crítica Cultural De la "gauche Divine". Pamplona: Editorial Laetoli, 2011. 2. Print.

Vollendorf, Lisa. Literatura Y Feminismo En España (s. Xv-Xxi). Barcelona: Icaria, 2005. Print.

Wilson, Elizabeth. The Sphinx in the City: Urban Life, the Control of Disorder, and Women.Berkeley: University of California Press, 1992. Print.

Woolf, Virginia. Three Guineas. New York: Harcourt, Brace and Co, 1938. 39. Print.

Zavala, Iris M, Cristina Dupláa, Mari J. Olaziregi, Busto M. J. Farina, and Briones B. Suárez. Breve Historia Feminista De La Literatura Española (en Lengua Catalana, Gallega Y Vasca). Rubí, Barcelona: Anthropos, 2000. Print. 


\section{ELISABETH LLAVERIA-POWELL}

Born, Sète, France

June, 1983

A.A. in Philosophy.Université Paul Valéry. Montpellier, France.

1983-1984. French Inshuctor. L' Alliance Francaise de Colima. Colima, Mexico.

1984-1986. French/Spanish Teacher. Lycee Francais de Los Angeles. Los Angeles, CA.

1988-1989

Translator/Interpreter certificate. Miami Dade College Miami, Florida.

1994-1998

1998-1999

B.A. (Summa cum laude) in French Literature. Florida International University. Miami, FL.

Award for Outstanding Academic Achievement in French.

Teaching Assistant (Spanish). Modem Languages Department. Florida International University. Miami, Florida.

$1999-2000$

Awarded a full scholarship by the Latin American and Caribbean Center. Florida International University.Miami, Florida.

Dec. 2000

M.A. in Spanish.

Qualifying Examinations passed with Honors

Florida International University. Miami, Florida.

2001-2004

Spanish teacher. Gulliver Academy-Middle Miami, Florida.

2004- 2006

Spanish and French lecturer. University of Miami, Florida.

Nov. 2005 Doctoral Candidacy Examinations passed. Florida International University. Miami, Florida.

2006- Present Spanish and French Senior lecturer. SPA 211 Spanish Coordinator. University of Miami, Florida. 


\section{PUBLICATIONS AND PRESENTATIONS}

Llaveria, Elisabeth. (Avril, 1980) "Amour et désir : Le vice-consul de Marguerite Duras." Paper presented at the conference Lis ta lettre à P. V. Paul Valéry, Université de Lettres, Montpellier 3. Montpellier, France.

Llaveria, Elisabeth. (Avril, 1981) "Pascal et l'ennui: Les Pensées de Pascal."Paper presented at the conference Lis ta lettre à P. V Paul Valéry, University de Lettres, Montpellier 3. Montpellier, France.

Llaveria-Powell, Elisabeth. (October, 1999). "Armor y aislamiento en Yerma de Federico García Lorca". Paper presented at the Second Florida International University Conference on Iberian and Iberian-Ametican Literature. Miami, FL. 